\title{
Constructed Narratives: The EU as a foreign policy actor in its relations with China
}

by

Julie Pickering

A thesis submitted to the Faculty of Graduate and Postdoctoral Affairs in partial fulfillment of the requirements for the degree of

Master of Arts

in

European, Russian and Eurasian Studies

Carleton University

Ottawa, Ontario

C 2013, Julie Pickering 
Library and Archives

Canada

Published Heritage

Branch

395 Wellington Street

Ottawa ON K1A ON4

Canada
Bibliothèque et

Archives Canada

Direction du

Patrimoine de l'édition

395 , rue Wellington

Ottawa ON K1A ON4

Canada
Your file Votre référence

ISBN: 978-0-494-94591-9

Our file Notre référence

ISBN: $978-0-494-94591-9$
NOTICE:

The author has granted a nonexclusive license allowing Library and Archives Canada to reproduce, publish, archive, preserve, conserve, communicate to the public by telecommunication or on the Internet, loan, distrbute and sell theses worldwide, for commercial or noncommercial purposes, in microform, paper, electronic and/or any other formats.

The author retains copyright ownership and moral rights in this thesis. Neither the thesis nor substantial extracts from it may be printed or otherwise reproduced without the author's permission.
AVIS:

L'auteur a accordé une licence non exclusive permettant à la Bibliothèque et Archives Canada de reproduire, publier, archiver, sauvegarder, conserver, transmettre au public par télécommunication ou par l'Internet, prêter, distribuer et vendre des thèses partout dans le monde, à des fins commerciales ou autres, sur support microforme, papier, électronique et/ou autres formats.

L'auteur conserve la propriété du droit d'auteur et des droits moraux qui protege cette thèse. $\mathrm{Ni}$ la thèse ni des extraits substantiels de celle-ci ne doivent être imprimés ou autrement reproduits sans son autorisation.
In compliance with the Canadian Privacy Act some supporting forms may have been removed from this thesis.

While these forms may be included in the document page count, their removal does not represent any loss of content from the thesis.
Conformément à la loi canadienne sur la protection de la vie privée, quelques formulaires secondaires ont été enlevés de cette thèse.

Bien que ces formulaires aient inclus dans la pagination, il n'y aura aucun contenu manquant. 


\section{Abstract}

EU-China relations have intensified in the last two decades, and today are organized as a strategic partnership that encompasses over 50 sectors of cooperation. This relationship, and the manner in which it has been approached by the EU, reveals some of the ways in which the latter organizes itself in its foreign policy capacity, and the kind of actor it tries to be in this relatively new policy field. The case of EU-China relations reveals that the EU has constructed two narratives about its actorness in foreign policythat of a strategic partnership, and that of normative actorness. Three cases- Market Economy Status, the Human Rights Dialogue, and cooperation on Africa-allow us to see the extent to which the EU presents these narratives discursively, and in a second time, instrumentalizes them. The question is raised as to whether the EU's discursive exercises, as well as the actions generated by these, contribute to any substantive power or ability to shape its relations with China. 


\section{Acknowledgements}

I am deeply grateful for the research funding provided by the European Union through the Centre for European Studies at Carleton University. This funding made possible a research trip to Belgium, during which research for this work was conducted.

Thank you to my family and friends for all their support, without which I would not have been able to complete this work.

To my parents, Hélène and George, brothers Marc and Patrick, and friend for life Jillian Normand, thank you for the unconditional love.

To Sara and Jason, the timing of this thesis coincides with a wonderful development in your lives, and I am so looking forward to sharing many happy moments with your new family.

To my advisors, Joan DeBardeleben and Crina Viju, thank you for your thoughtful instruction and for always making yourselves available. You have both played such important roles in my intellectual and academic development over the course of my graduate studies, and for this I am very grateful.

I would also like to thank EURUS and Jeff Sahadeo for providing me with extensive support and exciting opportunities over the past two years.

I would like to dedicate this work to my dear cousin Lt. Andrew Nuttall (1979-2009). You are deeply missed and continue to be a source of inspiration to me everyday. 
Table of Contents

ABSTRACT .II

ACKNOWLEDGEMENTS. III

LIST OF ACRONYMS. $V T$

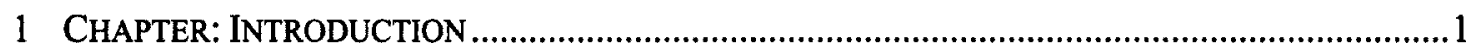

2 CHAPTER: OVERVIEW OF EU-CHINA RELATIONS ......................................................

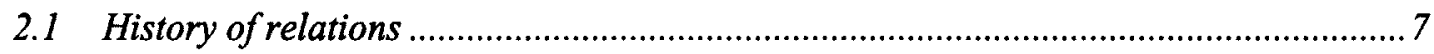

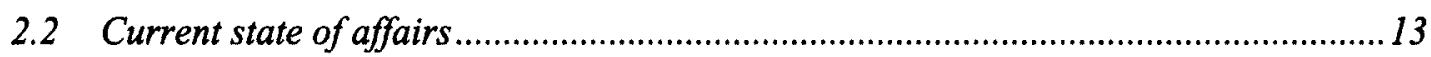

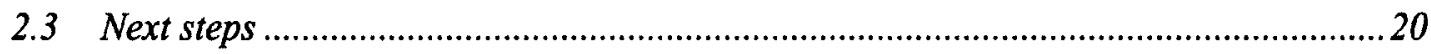

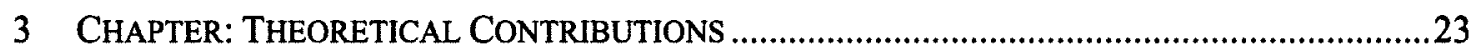

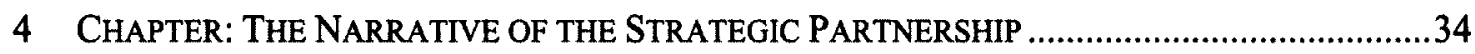

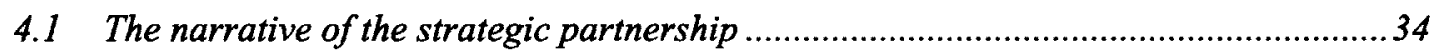

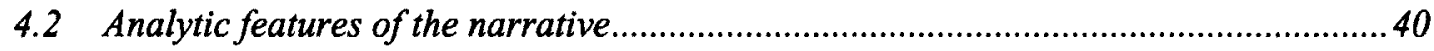

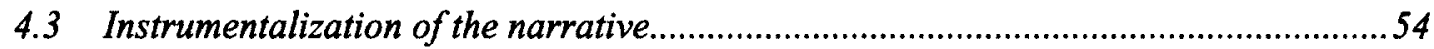

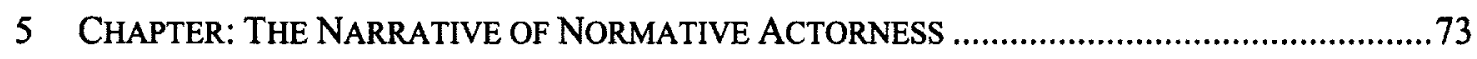

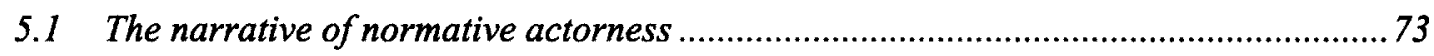

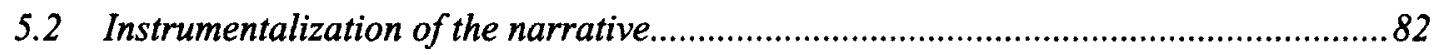

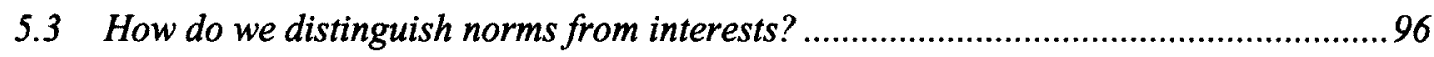

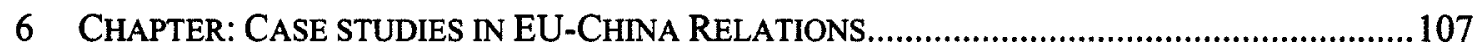

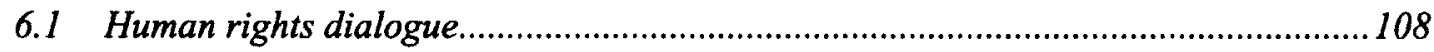

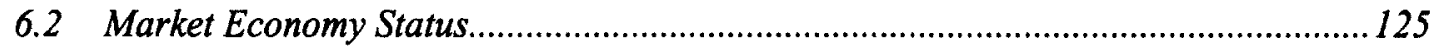

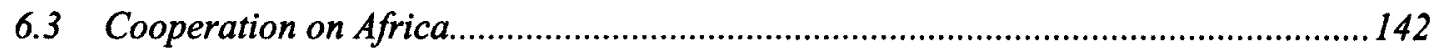

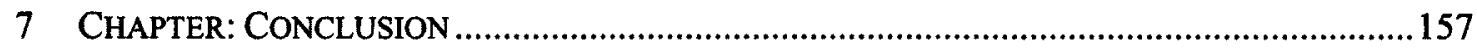

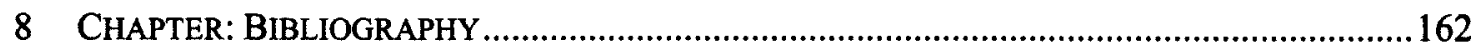




\section{List of Acronyms}

Brazil, Russia, India, China and South Africa (BRICS)

Common Agricultural Program (CAP)

Chinese Communist Party (CCP)

Common Foreign and Security Policy (CFSP)

Common Security and Defence Policy (CSDP)

Directorate Generales (DG)

Economic Community (EC)

European External Action Service (EEAS)

European Political Cooperation (EPC)

European Security Strategy (ESS)

European Union (EU)

Forum on China-Africa Cooperation (FOCAC)

General System of Preferences (GSP)

Global Public Goods (GPG)

Human Rights Council (HRC)

Industrialised Countries Instrument (ICI)

International relations (IR)

Market Economy Status (MES)

Market Economy Treatment (MET)

Normative Power Europe (NPE)

Organisation for Economic Co-operation and Development (OECD)

Partnership and Cooperation Agreement (PCA) 
Report on the Implementation of the European Security Strategy (RIESS)

Shanghai Cooperation Organization (SCO)

Trade and Economic Cooperation Agreement (TECA)

United Nations (UN)

United Nations Security Council (UNSC)

World Trade Organization (WTO) 


\section{Chapter: Introduction}

The EU's relations with China have grown exponentially over the past two decades, and today comprise one of Brussels' most comprehensive and intensive external relations. Officially, a strategic partnership has emerged between the two actors, solidifying a bond based foremost on economic, but also political, social and cultural cooperation. The EU is currently China's largest trading partner, and China is the EU's second after the United States. ${ }^{1}$ This relationship is multi-vectored and based on engagement and partnership in a multitude of policy areas. Along with a trade agreement, there are over 50 dialogues between the two actors, dealt with in annual summits, regular political visits and working groups. ${ }^{2}$

Since 2007, negotiations have been underway for the completion of a comprehensive Partnership and Cooperation Agreement (PCA), which the EU has with many of its neighbours, including Russia, the Ukraine and Moldova. The negotiations on the agreement- which would both update the 1985 trade agreement and unify the EU's strategy towards China in political, social and cultural cooperation- have been slow and difficult, and currently seem to be stalled. This, in part, reveals different understandings and expectations from the two parties of the relationship, its aims and motivations.

It also provides an excellent starting point for analyzing the ways in which the EU constructs and comprehends its relations with China. This thesis argues that the EU actually promotes two narratives in its relations with China through its high-level

\footnotetext{
${ }^{1}$ European Commission, "Countries and Regions- Chiná," accessed January 2013, thttp://ec.europa.eu/trade/creating-opportunities/bilateral-relations/countries/china/

${ }^{2}$ European External Action Service, "China," accessed January 2013, http://eeas.europa.eu/china/index en.htm
} 
discourse: that of the strategic partnership and that of normative actorness. The first, while also the name given to the framework used by the EU for its political engagement with China, is used by the EU as a narrative in its foreign policy, describing one way in which it engages major countries like China. This narrative is implicitly found in the EU's official documents and pronouncements, and describes the means by which the EU will engage both emerging and traditional powers, and how it aims to maintain the EU's relevance in a changing world. Specifically, the narrative relates to the EU exercising and promoting 'effective multilateralism' through engagement and dialogue that will benefit both sides. The narrative, and certainly the instrument, both focus on interest-based engagement that will foster mutual benefits and, hopefully, increasing convergence of interests in the long-term.

The second narrative is one of normative actorness. Identification of this narrative is heavily rooted in academic contributions to the study of the EU's foreign policies and global actorness, which makes it slightly different than the first. While the EU does not reference this narrative as a direct concept in its foreign policy documents, it uses a great deal of normative language suggesting the use of a narrative in its discourse, which often times mirrors themes drawn out in academic works on the EU's role in foreign affairs. This narrative focuses on the EU 'bettering' the world and adhering to certain values and ideals because of their intrinsic quality. Many commentators propose that the EU is unable to exercise any normative power with a state like China. As will be shown, some of these critiques are justified, and the EU is unable to exercise much of this power towards China. Yet the EU may still be using the narrative to describe its relations with China, and possibly to generate actions. Furthermore, the definition of normative 
narrative in this piece is inclusive of economic and market norms, such as liberal economic principles and market regulations.

The logics of the narratives are then seemingly different: one is more interestbased, and one is more ideational. The two seem to differ in discourse and in practice. Does either narrative help elucidate the EU's behavior towards China? Implementing its policy towards China, is the EU acting more in accordance to the logic of one or the other? Are the two vastly different, as it may seem initially, or are they in fact two sides of the same coin? Each narrative will be discussed separately. In the first part of each section, a discourse perspective will be presented, in which the EU's own discursive narrative-creation will be examined, and key documents and statements highlighted. In the second part, both narratives will be examined in their instrumentation, which will be organized slightly differently for both sections. The analysis then has two purposes: one is to establish whether the discourse creates and supports the narrative, the second is to see whether the narrative is turned into concrete action, which we call instrumentalization or actualization. This exercise will allow us to see whether the EU is acting according to the logic of each narrative, and whether the EU is successful in applying these.

In Chapter 2, a brief history of official EU-China relations will be provided. A look at expansion and intensification of these relations will illustrate certain trends, after which the areas of cooperation and tension will be evaluated.

In the Chapter 3, theoretical foundations of the EU's actorness will be analyzed using constructivist theory. The concept of political narratives will be briefly introduced, and studied in the context of EU studies. 
In Chapters 4 and 5, a thorough analysis and conceptualization of each narrative will be presented, starting with the strategic partnership narrative. For each chapter, the narrative will be presented in the EU's discourse, in which analytic/ descriptive features will be presented on the rhetorical and practical aspects of the narratives, including support provided by secondary literature. An attempt will then be made to ask to what extent these narratives are instrumentalized or actualized in practice, which will allow us to propose possible difficulties associated with EU attempts to implement these broadly, and also specifically with regards to EU-China relations.

In Chapter 6, three case studies have been selected to reflect the different areas encapsulated in official EU-China relations. The analysis presented in Chapters 4 and 5 will be applied, as both narratives are tested in the specific case studies.

My hypothesis is the following: the EU discursively constructs these narratives, and these are often used as justification for actions- for instrumentalization- in its relations with China. However, very major ambiguities emerge in the narratives that prevent them from being comprehensive descriptive tools, and the EU's difficulty in actually being an effective power vis-à-vis China indicates their only partial usefulness. For a variety of reasons, the EU cannot always implement the narratives, and even when it does instrumentalize them, it sometimes faces difficulty in actually having any direct power. The result is that the EU often ends up acting either in an ad hoc fashion, referencing both narratives, or acting outside of the narratives, perhaps in accordance with a variety of different logics. Furthermore, the two narratives appear to be rather complementary, and while limited in their descriptive abilities, still work to explain part of the EU's type of actorness towards China. This study, then, contributes to the literature 
on the EU in world affairs mainly by proposing a double constructivist reading: it applies a constructivist approach to the study of the EU, arguing that these contemporary international relations may be understood to a large extent using a constructivist approach, but also establishing that the EU views itself as a constructivist actor, at least somewhat engaging in a constructivist exercise on its actorness in foreign policy using, among other things, specific narratives.

Methodology: The methodology in this thesis will be exclusively qualitative. The research is based on discourse analysis of official texts, which are taken together as the basis of the EU's narrations. These documents reveal the EU's self-perception, the type of entity it believes it is, and the way it believes others view it. A number of official Chinese government documents have been used to establish the Chinese position, and also serve to illustrate in part how the EU is viewed and perceived externally. In addition, newspaper articles from international popular newspapers, journals and think-tanks have been used to corroborate or explicate certain positions, or provide examples of how certain actions or policies are viewed by a broader community or the public.

In terms of language, English has been used almost exclusively. French is the second language of study, though given the nature of EU publications, knowledge of French was not indispensable for this analysis. In order to fulfill the language requirement for this thesis, this author cited French-language media and political commentary, which allowed for access to France and Belgium's EU studies community. Newspaper articles from popular newspapers and information from France's embassy in Beijing and its Foreign Ministry have been used to provide a broader scope of analysis. 
English-language translations of official Chinese documents were provided online by the Chinese government, and knowledge of Chinese language was therefore not required.

This author also conducted structured interviews in May and August of 2012 with European officials and academics in both Beijing and Brussels, which are used as background information, secondary sources and direct primary research. Funding from the European Union granted by Carleton University's Centre for European Studies permitted this research. The research more broadly was measured and validated by qualitative research principles of observation and content/discourse analysis.

Level of analysis: For the sake of this work, the level of analysis remains at the EU institutional level. While in some instances the interests and identities of the member states will be analyzed, it is not done in any great depth in this work, and for conciseness and clarity, the EU is treated here as a single actor. Within the EU, a variety of actors and institutions are referenced, though the Council of Ministers, European Council, European Commission, and European Parliament receive the most attention. 


\section{Chapter: Overview of EU-China Relations}

\subsection{History of relations}

China and the EU both view each other as rising forces in the world. Their relationship has grown rapidly over the past two decades, as they have both attempted to engage the other.

For the first decades of the post-WWII era, Europe and China viewed the other as foreign and outside of their respective spheres of influence. This changed around the 1970s, with formal relations finally being established in $1975 .{ }^{1}$ Over the past four decades, the relationship has broadened and deepened in scope and intensity, and today is one of the EU's most important foreign policy concerns. ${ }^{2}$

Over time, the two actors have become familiar with each other, and today the relationship has reached a point where the underlying tensions and problems are visible, though both sides are still keen to engage the other. The existing literature on this relationship has comprehensively outlined the recent trends: major overtures were made by both sides in the 1990s, highlighting the eagerness of the parties to re-engage one another politically and economically post-Tiananmen. The first EU policy paper on China, A long-term policy for China-Europe relations, was published in 1995, highlighting that "Europe's relations with China are bound to be a cornerstone in

\footnotetext{
${ }^{1}$ European External Action Service, "China."

${ }^{2}$ Franco Algieri, "It's the system that matters: institutionalization and making of EU policy towards China," in China-Europe Relations: Perceptions, policies and prospects, Eds. David Shambaugh, Eberhard Sandschneider and Zhou Hong (London: Routledge, 2008): 65
} 
Europe's external relations, both with Asia and globally." It identified the EU's role as that of guiding and "assisting China's emergence."4 This signaled the beginnings of constructive engagement, which is defined by the Commission as "the opportunity offered ... to promote a responsible and constructive Chinese role." The 1995 publication has been followed by documents in 1998, 2001, 2003, and $2006 .^{6}$

In addition to the literature published by the Commission, high-level political meetings were initiated in 1998. Today, the high-level EU-China Summit, which brings together EU and Chinese leaders annually, is simply the 'tip of the iceberg' of EU-China relations. $^{7}$

2003 was an important year in EU-China relations, with both sides publishing important papers on the subject. The European Security Strategy (ESS), published that year, identified China as a strategic partner for the EU. ${ }^{8}$ The Commission's 2003 communication, A maturing partnership, identified the successful intensification of trade as a success story. It was in this document that the dialogues were first organized under the banner of a strategic partnership, claiming that the two actors are working "together as strategic partners to safeguard and promote sustainable development, peace and

\footnotetext{
${ }^{3}$ European Commission, A Long Term Policy for China-Europe Relations, COM (1995) 279, accessed May 2012, http://eeas.europa.eu/china/docs/com95 279 en.pdf

${ }^{4}$ Mikael Mattlin, "A Normative EU Policy Towards China: Mission Impossible?" The Finnish Institute of International Affairs, Working Papers, 67 (2010): 5

${ }^{5}$ Richard Balme,"From Hard to Soft Power, and Return? The European Union, China and Human Rights." Governance and Globalization, Sciences Po in China (November 2007):1, accessed May 2012, http://sciencespo-globalgovernance.net/? $\mathrm{q}=$ webfm send/21; A Long Term Policy for China-Europe Relations.

${ }^{6}$ European External Action Service, "China"

${ }^{7}$ Pierre Defraigne, "Pourquoi la Chine veut une Europe forte?" Madariaga Paper, 5:2 (September 2012) accessed January 2013. http://www.madariaga.org/publications/madariaga-papers/748-pourquoi-la-chineveut-une-europe-forte

${ }^{8}$ European Council, $A$ Secure Europe in a Better World: European Security Strategy, December 12, 2003, 13, accessed May 2012, http://consilium.europa.eu/uedocs/cmsUpload/78367.pdf
} 
stability." It is "in the clear interest of the EU and China to work as strategic partners on the international scene." ${ }^{10}$ The paper of 2006, EU-China: Closer Partners, Growing Responsibilities, further sets out a framework for the EU-China strategic partnership as one of "engagement and partnership.".11

Overall, relations were at an all-time high during the early 2000 s, in what some called the EU-China 'honeymoon." ${ }^{12}$ At this time, "Europe and China seemed to have found each other, and it was all about win-win, and indeed, ever since trade has been booming." ${ }^{, 13}$ Romano Prodi, former President of the Commission, seems to have first introduced this analogy to romantic relationships, saying in 2004 of the EU-China strategic partnership, "if it is not a marriage, it is at least a very serious engagement."14 Yet this period also saw numerous problems arise that would strain the relations. Others have written of the relationship reaching a 'bottleneck', or moving from a 'honeymoon' to a 'marriage,' in which problems emerge. ${ }^{15}$ In 2005 , the Europeans decided to not lift the arms embargo on China, in place since the Tiananmen massacre of

\footnotetext{
${ }^{9}$ European Commission, Communication from the Commission, A maturing partnership- shared interests and challenges in EU-China relations, 10 September 2003, COM(2003) 533 final, 3, accessed May 2012. http://eur-lex.europa.euexUriServ/LexUriServ.do?uri=COM:2003:0533:FIN:EN:PDF

${ }_{10}$ A maturing partnership, 7

${ }^{11}$ European Commission, Communication from the Commission, EU-China: Closer partners, growing responsibilities. October 24, 2006, COM (2006) 631 final, 2, accessed May 2012. http://eurlex.europa.eu/LexUriServ/LexUriServ.do?uri=COM:2006:0631:FIN:EN:PDF

12 Jing Men, "Great expectations, complex reality," EU-China Observer, 3 (2011): 2, accessed May 2012. http://www.coleurope.eu/sites/default/files/research-paper/eu china observer_3_2009.pdf

${ }^{13}$ Geeraerts, Gustaaf, Interview with Julie Pickering, May 2012, Brussels

${ }^{14}$ Paul Haydon, "Human rights and the development of EU-China relations: a critical analysis of the EU's normative power," POLIS Journal, 5 (Summer 2011): 13, accessed January 2013, http://www.polis.leeds.ac.uk/assets/files/students/student-journal/ug-summer-11/paul-haydon.pdf ${ }^{15}$ Zhang Jiao, "The EU-China Relationship Arriving at a Bottleneck- A Look at the Ongoing Negotiation of the PCA," EU-China Observer, 4 (2011): 2, accessed May 2012, http://www.coleurope.eu/sites/default/files/research-paper/eu_china observer 4 2011.pdf; David Shambaugh, Eberhard Sandschneider and Zhou Hong, "From honeymoon to marriage: prospects for the China-Europe relationship," in China-Europe Relations: Perceptions, policies and prospects, Eds. David Shambaugh, Eberhart Sandschneider and Zhou Hong (London: Routledge, 2008): 303; this sentence was taken from an essay written for a different class
} 
1989, which led to criticism from the Chinese of Europe remaining under US sway. The growing trade deficit in Europe has continued to be a source of tension, of particular salience to the European public, who seem to be almost suspicious of China. While EU member states have a surplus in trade in services and investment, this in no way makes up for the overall $€ 159.9 \mathrm{bn}$ trade deficit ( 2011 figure) ${ }^{16}$ Overall, limitations became apparent regarding the promises of the early 2000 s, as both partners displayed their displeasure with the other.

In terms of perceptions, the EU views China's economic rise with both admiration and fear, though it has not traditionally viewed China as much of a military threat as the Americans have. However, recent public opinion survey results reveal that the 2012 South China Sea dispute, among other things, has led to a "convergence" in EU and American attitudes regarding China as a military threat. ${ }^{17}$ Still, China has been typically viewed as a land of opportunity for Europeans firms, as well as a country the EU should cooperate with and could help integrate into world affairs.

From the Chinese side, Beijing has long understood its relationship with the EU and its predecessors as dealing with more than simply economic and trade considerations. The Chinese leadership portrays the engagement and cooperative relationship in a generally positive light; they present the EU as an important global actor and ally to

\footnotetext{
${ }^{16}$ European Commission, "Facts and figures on EU-China trade- Did you know?" accessed January 2013. http://trade.ec.europa.eu/doclib/docs/2009/september/tradoc 144591.pdf

${ }^{17}$ Kliman, Daniel M. "Survey: EU More Likely to View China as Military Threat Than Previous Years," Video. September 24, 2012. Accessed December 2012. http://www.gmfus.org/archives/survey-eu-morelikely-to-view-china-as-military-threat-than-previous-years/
} 
China in its 'Peaceful Rise. ${ }^{18}$ This is often portrayed in contrast to the US, which are seen to be more hardline and quick to view China as a military threat.

Beijing's analysis of the world system was for a long time grounded in Maoist interpretations of geopolitics, which viewed the global structure in terms of dialectics and clashes of forces. Within this narrative, the contradictions of the capitalist system, particularly evident in the United States, and the inherent tensions of the bipolar structure would give way to the rise of a multipolar system, in which China would itself be a pole. For the first post-WWII decade, China viewed the European Economic Community as an extension of the United States, part of the NATO group. ${ }^{19}$ Yet by the 1960 s, Beijing began to view an integrated Europe as a counter to USSR and US hegemony. ${ }^{20}$ The Chinese Communist Party (CCP) saw the integrative efforts of the European countries in terms of systemic shifts and its potential in the world order. Chinese Minister of Foreign Trade Li Qiang was quoted as saying in 1975 that EU-China cooperation was "a positive development in the international system...(it) will certainly frustrate the schemes of the superpowers seeking world hegemony."21

The Chinese were eager to see more European integration, and they supported the project on the grounds that this would permit Europe to move away from dependence on the United States. Chinese Premier Zhou Enlai's "euro-passion" in the early 1970s culminated in the 1975 establishment of diplomatic relations, during which EC

\footnotetext{
${ }^{18}$ Kenneth Chan, "Images, visibility and the prospects of soft power of the EU in Asia: the case of China," Asia Europe Journal, 8 (2010): 133

${ }^{19}$ David Scott, "China-EU convergence 1957-2003: towards a 'strategic partnership," Asia-Europe Journal, 5 (2007): 218

${ }^{20}$ Ibid

${ }^{21}$ Op. cit., 219
} 
Commission Vice-President Nicholas Soames visited Beijing. ${ }^{22}$ The CCP has been, since the 1960s, an official supporter of European integration, lauding further integrative developments. ${ }^{23}$

No doubt the earlier Chinese commentaries on the then EC's role in global affairs worked to invigorate Europeans in their dealings with Beijing. European officials working in 1975 saw a vision of the EU emanating from Beijing that corresponded to their own ideals, if not necessarily a reality. The European Parliament, in particular, voiced support for closer EC-China relations. It was called "probably the most farreaching event to take place in the field of the Community's external relations. ${ }^{.24}$ With the European Political Cooperation (EPC) launched in 1970, there was an opportunity for Brussels to exercise its newfound jurisdiction in external relations. In this sense, the establishment of formal diplomatic relations with China was also a self-reflexive exercise for the EU; a moment of 'acting into being.'

Today, Beijing continues to view the European Union as a counter to American hegemony. ${ }^{25}$ In 2003, Beijing published its EU Policy Paper, the first of its kind to be published by the CCP. ${ }^{26}$ The document outlined China's desire to work with the EU on a variety of global challenges and policy areas, ranging from the fight against global terrorism to intercultural exchanges. It made numerous references to foreseeable shifts in

\footnotetext{
${ }^{22}$ Scott, "China-EU convergence 1957-2003," 219; Finn Laursen, "The EU's Strategic Partnerships: The Case of EU-China Relations," Dalhousie EUCE Occasional Paper, 10 (2011) accessed June 2012, http://euce.dal.ca/Files/EUCE Occasional Paper_No 10 2011.pdf

23 "China's EU Policy Paper," October 2003, Ministry of Foreign Affairs of the People's Republic of China, accessed March 2012.http://www.fmprc.gov.cn/eng/topics/ceupp/t27708.htm

${ }^{24}$ Scott, "China-EU convergence 1957-2003," 220

${ }^{25}$ Nicola Casarini, "China's Approach to US debt and the Eurozone crisis," China's Geoeconomic Strategy, LSE IDEAS, 46, accessed February 15, 2013, http:/www2.lse.ac.uk/IDEAS/publications/reports/pdf/SR012/casarini.pdf

${ }^{26}$ Men, "Great expectations, complex reality," 2
} 
the world order, in which its relations with the EU would be important, and both would be poles. ${ }^{27}$ Beijing saw EU enlargement and the introduction of the Euro as signs of the union's strength, believing it to be an antidote to US hegemony ${ }^{28}$ As stated in the $E U$ Policy Paper, "the European Union (EU) is a major force in the world. China attaches importance to the role and influence of the EU in regional and international affairs. To strengthen and enhance China-EU relations is an important component of China's foreign policy."29

\subsection{Current state of affairs}

EU-China relations today can best be described as complicated. They are a field of study growing in academia, particularly within the EU, but also in China. David Shambaugh has called it "one of the most important yet least appreciated developments in world affairs in recent years.",30

This relationship has formally been organized as a strategic partnership since $2003 .^{31}$ The partnership is a framework for the relations, which includes three pillars: a Political Dialogue (Pillar I), an Economic and Sectoral Dialogue (Pillar II) and a Peopleto-People Dialogue (Pillar III). Within each of these 'pillars' there are numerous working groups and more specific dialogues on either political, economic/sectoral or people-topeople and cultural issues. ${ }^{32}$ The strategic partnership as an instrument for organizing

\footnotetext{
27 "China's EU Policy Paper."

${ }^{28}$ Cameron, Fraser, Interview with Julie Pickering, May 2012, Brussels

29 "China's EU Policy Paper."

${ }^{30}$ David Shambaugh, "China and Europe: The Emerging Axis," The Brookings Institute (September 2004), accessed April 2012, http:/www.brookings.edu/research/articles/2004/09/china-shambaugh

${ }^{31}$ Scott, "China-EU convergence 1957-2003," 228

${ }^{32}$ European External Action Service, "EU-China Dialogue Architecture - main elements," accessed January 2013, http://eeas.europa.eu/china/docs/eu china dialogues en.pdf
} 
EU-China relations is defined by the summitry: annual high-level EU-China summits, meetings of EU-China Ministerial Troika, as well as a separate high-level strategic, trade and economic, and people-to-people dialogues.

In Brussels, a variety of Directorate Generales (DGs) have desk officers working on Chinese or Far East files; the plethora of sectors and policy areas mean that almost every EU institution and Commission DG is involved in some capacity in formulating and practicing a China policy, from DG Energy to DG Culture. Still, the European External Action Service (EEAS) is in charge of organizing and coordinating the strategic partnership due to its function of implementing the intergovernmental Common Foreign and Security Policy (CFSP). The EEAS has a China desk in charge of streamlining EU relations with the country. It oversees the organization of the summits and the strategic Dialogue, and helps monitor and coordinate sectoral dialogues. The desk also oversees the use of Industrialised Countries Instrument (ICI) and instruments through which funding for EU-China projects is channeled.

The EU has explained that it supports China's rise in the international arena and its transition to a more open society. Officially, the EEAS says the EU's China policy today is fourfold: " to engage China further, both bilaterally and on the world stage, through an upgraded political dialogue; to support China's transition to an open society based upon the rule of law and respect for human rights; to encourage the integration of China in the world economy through bringing it fully into the world trading system, and 
supporting the process of economic and social reform that is continuing in China; to raise the EU's profile in China.",33

The first pillar of the partnership deals with political areas, and includes the Strategic Dialogue, and a number of working groups and dialogues on areas ranging from human rights to security and defence. Economic relations are managed at the EU-level mainly through the second pillar, the Economic and Sectoral Dialogues, which includes the annual High Level Economic and Trade Dialogue. ${ }^{34}$ Most recently, the People-toPeople dialogue has been created, and forms the third pillar of the Strategic Partnership. ${ }^{35}$ In fact, 2012 was the "EU-China Year of Intercultural Dialogue," during which a number of projects, including some on education and cultural exchanges, were initiated. ${ }^{36}$ The European Parliament also participates in all three pillars of the strategic partnership, has a specific 'delegation' on China and hosts a parliamentary exchange with Chinese political parties. $^{37}$

The widening of the relations to encompass so many policy fields reveals the dynamism with which the two parties engage each other at the high-level. The sectoral dialogues and working groups range from the technical (dialogue on agriculture) to the political (regular dialogue on security and defence policy) to the cultural. These reflect a breadth of policy areas and the desire of both actors to work as partners, and establish forums and methods for exchanges and policy coordination.

\footnotetext{
33 "Political and economic relations, The European Union and China: A Maturing Partnership," Delegation of the European Union to China, accessed January 2013, http:/leeas.europa.eu/delegations/china/eu china/political relations/index en.htm

${ }^{34}$ Council of the European Union, "Joint Press Communique, $15^{\text {th }}$ EU-China Summit, Towards a stronger EU-China Comprehensive Strategic Partnership," September 20, 2012. 14022/12 (Presse 388): 2, accessed October 2012. http://www.consilium.europa.eu/uedocs/cms data/docs/pressdata/en/ec/132507.pdf

${ }^{35}$ Ibid

${ }^{36}$ EU official, Interview with Julie Pickering, May 2012, Brussels

${ }^{37}$ Van de Camp, Wim, Interview with Julie Pickering, May 2012 Brussels
} 
In practical terms, despite the breadth of scope of the strategic partnership, economic relations dominate. The figures in trade are extremely significant: China is the EU's second largest trading partner after the US, and the largest source of its imports, while the EU has been China's largest trading partner since $2005 .{ }^{38}$ The figures are even more striking given that trade was relatively minimal only two decades ago. ${ }^{39}$ Within the European Union, Germany is by far China's most important trading partner, with France and the UK also major players. ${ }^{40}$ There is little doubt that China's economic rise is central to the EU's desire to seek a rapprochement.

Along with the success story of EU-China economic collaboration, a number of sensitive areas have emerged which potentially block advancement and deepening of their relations. The trade deficit with China, for example, has been an increasingly important problem. Former EU Trade Commissioner Peter Mandelson said that the EU's trade deficit with China has "been growing by fifteen million Euros every hour and that it is unsustainable. ${ }^{\not 1}$

Another irritant for the EU is the perceived protectionism in China, which prevents market access for European firms and harms European competitors. ${ }^{42}$ The EU is interested in higher investment in the Chinese market, but it is limited by barriers to foreign ownership. The EU remarks that the Chinese will only grant greater access on

\footnotetext{
${ }^{38}$ Delegation of the European Union to China, "Trade Relations," accessed January 2013, http://eeas.europa.eu/delegations/china/eu china/trade/index en.htm

39 "Facts and figures on EU-China trade- Did you know?"

${ }^{40}$ Gudrun Wacker, "Changes and continuities in EU-China relations : a German perspective, » in USChina-EU Relations: Managing the new world order, Eds. Robert Ross, Øystein Tunsjø and Zhang Tuosheng (London: Routledge, 2010): 79

${ }^{41} \mathrm{Ibid}$

${ }^{42}$ European Commission, "Mandelson in China: EU-China trade deficit "measure of our untapped potential," "' 27 November 2007, accessed February 2013, http://trade.ec.europa.eu/doclib/docs/2008/january/tradoc 137536.pdf
} 
certain conditions, including high-technology transfers. Trade Commissioner Karel De Gucht said in 2012 that these market access "obstacles range from mandatory joint ventures that apply to cars to the outright ban on foreign ownership in large parts of the postal services market... in some cases the right to invest is conditional on forced technology transfer." ${ }^{43}$ This protectionism also applies to the Chinese use of export quotas on raw materials and natural resources, and a case flared up in the summer of 2012 with regards to restrictions on the sale of rare earth elements, in which China was accused of violating its obligations under the WTO. ${ }^{44}$

Protection of intellectual property rights and enforcement of existing laws is a perennial problem in China's relations with all developed economies. EU firms perceive this to be a massive barrier to high-tech exports to China. It is also an issue of counterfeit goods manufactured in China entering the EU; DG Trade estimates that $73 \%$ of counterfeit goods caught at EU border crossings in 2011 originated in China. ${ }^{45}$ The issue for the Europeans is often not so much lack of adequate legislation, but lack of enforcement and transparency. These gaps are a sore point in the attempts to initiate an investment agreement, given that for the EU, any such agreement would likely cover market access, in which protection of European investment and property would be required by the Chinese.

Politically, a number of areas have dominated the bilateral relations. The Tibet question has been a thorn in China-EU relations, though largely for symbolic reasons.

\footnotetext{
${ }^{43}$ Robin Emmott and Alan Wheatley, "China must drop barriers to European investment, EU says," Reuters, June 7, 2012, accessed on February 18, 2013, http://www.reuters.com/article/2012/06/07/useurope-china-investment-idUSBRE85611B20120607

44 "Facts and figures on EU-China trade- Did you know?"

${ }^{45}$ Ibid
} 
Meetings with German and French officials were cancelled by the Chinese after Merkel and Sarkozy's respective meetings with the Dalai Lama in 2007. Taiwan is another politically sensitive topic, though the EU is officially committed to the 'One-China' policy. ${ }^{46}$ The Chinese are particularly sensitive about Taiwan and Tibet with the Europeans, whom they perceive to be supportive of succession and formal independence for the territories. While there is public support in the EU, particularly of the Tibetan cause, at the official EU-level there is no recognition of either territory's independence. ${ }^{47}$ Human rights also feature in the relations, though at some times more prominently than others, and many are critical of the EU's comportment on this issue. ${ }^{48}$

Global issues have also become more important over the past few years. This more global focus has increased since the early 2000 's, including the creation of dialogues and working groups on climate change, energy and urbanization. In terms of geopolitics, energy and energy security have featured prominently in the EU-China relationship in recent years, where the two "are kind of experiencing a honeymoon." ${ }^{, 49}$ This is an area of interest to the EU because of China's growing role in the energy markets and its position as the largest emitter of greenhouse gases. ${ }^{50}$ Many member states actively engage in this sector, notably Germany, the UK and the Scandinavian countries, and on this the Chinese have shown a great willingness to learn from the Europeans and European firms. This was the area of focus during a recent visit by newly incumbent Li Keqiang to Brussels in

\footnotetext{
${ }^{46}$ Cameron, Fraser, Interview with Julie Pickering, May 2012 Brussels

${ }^{47} \mathrm{Ibid}$

${ }^{48}$ Freeman, Duncan, Interview with Julie Pickering, May 2012 Brussels

${ }^{49}$ EU official, Interview with Julie Pickering, May 2012, Brussels

${ }^{50}$ Bates Gill, « China's Evolving Appraoch to Multilateralism and Global Governance : Implications for the European Union," in The Role of the European Union in Asia: China and India as Strategic Partners, Eds. Bart Gaens, Juha Jokela and Eija Limnell (Surrey: Ashgate Publishing, 2009): 155
} 
May $2012 .^{51}$ The EU wants to promote a cooperative approach in this area, as it sees China's growing presence in many regions of the world, particularly Central Asia and recently in the South China Sea. ${ }^{52}$

The two actors are also concerned with the issue of non-proliferation, and they signed a Joint Declaration on Non-Proliferation and Arms Control at the 2004 EU-China Summit, on which they promised to work together towards this goal. China has proven to be a constructive player in this field, and has worked closely with France, Germany and the UK..$^{53}$ These three played a role in persuading China to allow sanctions against Iran. $^{54}$

From the Chinese point of view, the lifting of the arms embargo and granting of Market Economy Status (MES) have been top 'asks' to the EU that are brought up at every high-level meeting. ${ }^{55}$ The two actors' abilities to resolve these issues are seen as a major test of their relationship. The arms embargo has led to a great deal of tension, and it is recognized in all studies of the relationship as a major irritant and source of hostility. It also reveals the competing interests between the EU's member states, though at this point, it is more symbolic than anything. ${ }^{56}$ France and the UK have actually been selling arms to China since the 1990 s, though officially the embargo is still in place. It has been

${ }^{51}$ EU official, Interview with Julie Pickering, May 2012, Brussels

${ }^{52}$ Ibid

${ }^{53}$ Bates Gill, "China's Evolving Approach," 147

${ }^{54}$ John Fox and Francois Godement, eds., A Power Audit of EU-China Relations, European Council of Foreign Relations Policy Report, 17 April 2009, 40. Accessed in May 2013, http://ecfr.eu/page/ECFR12 - A POWER AUDIT OF EU-CHINA RELATIONS.pdf

${ }^{55}$ Mikael Mattlin, «Thinking Clearly on Political Strategy: The Formulation of a Common EU Policy Toward China, " in The Role of the European Union in Asia: China and India as Strategic Partners, Eds. Bart Gaens, Juha Jokela and Eija Limnell (Surrey: Ashgate Publishing, 2009): 105; "Sommet Chine-UE: Pékin réclame moins de protectionnisme commercial," Le Monde, September 20, 2012, accessed January 2013, http://www.lemonde.fr/economie/article/2012/09/20/sommet-chine-ue-pekin-reclame-moins-deprotectionnisme-commercial 1763089 3234.html

${ }^{56}$ Wacker, "Changes and continuities in EU-China relations, " 89; Renard, Thomas, Interview with Julie Pickering, May 2012, Brussels 
proposed that the embargo is the biggest test of the EU's cohesive policy towards China, trying the ability of member states to work together. ${ }^{57}$ The Chinese have expressed disappointment with the EU's seeming inability to withstand US pressures on this subject. $^{58}$

What is without a doubt is that China and the EU are as interdependent as ever. China has taken the opportunity of Europe's economic downturn to invest heavily in infrastructure and bid for procurement at the national level. The EU, for its part, is currently focused on increasing levels of investment into China. There is a desire in Brussels for the two to reach some investment agreement, though the process is still in its infancy. ${ }^{59}$

\subsection{Next steps}

At the most recent EU-China Summit, held in late September 2012, Wen Jiabao reiterated that both actors "support a multipolar world and oppose unilateralism." ${ }^{60}$ The occasion was used as a farewell for Wen Jiabao, who was replaced at the CCP leadership convention of November 2012. In his introductory statement, Wen Jiabao reflected on the EU-China relations of his past 10 years in power. While the Chinese admire and support

\footnotetext{
${ }^{57}$ Mattlin, «Thinking Clearly on Political Strategy,» 120

${ }^{58}$ Liselotte Odgaard and Sven Biscop, "The EU and China: Partners in Effective Multilateralism?" in The International Politics of EU-China Relations, Eds. David Kerr and Liu Fei (Oxford: Oxford University Press, 2007): 75

${ }^{59}$ European Commission, “Countries and Regions- China," accessed January 2013, thttp://ec.europa.eu/trade/creating-opportunities/bilateral-relations/countries/china/

${ }^{60}$ Don Melvin, "EU-China Summit Opens with Emphasis on Trade," Associated Press, September 20, 2012, accessed December 4, 2012, http://bigstory.ap.org/article/eu-china-summit-opens-emphasis-trade
} 
the European integration project, he said, they are disappointed with the continued withholding of MES status for China and maintenance of the arm's embargo. ${ }^{61}$

In a joint statement at the EU-China Summit in 2006, the two actors announced that, in acknowledging the "full breadth and depth of today's comprehensive strategic partnership between the EU and China, the two sides agreed to launch negotiations on a new PCA which will encompass the full scope of their bilateral relations, including enhanced cooperation in political matters. ${ }^{.62}$ In January 2007, negotiations began for the implementation of this PCA, which would both update the 1985 Trade and Economic Cooperation Agreement (TECA) and unify the EU's strategy towards China in political, social and cultural cooperation. ${ }^{63}$ These negotiations have been slow and difficult, and at the moment seem to be stalled. Some are uncertain that it will ever come to fruition. ${ }^{64}$

The Chinese side would like to update the economic and trade agreement, but seems less willing to develop a more comprehensive agreement. ${ }^{65}$ One of China's main issues in re-negotiating the terms of the TECA is the MES status, which would have both symbolic political and economic consequences, specifically related to anti-dumping cases. ${ }^{66}$ While for the Chinese side the focus is more pragmatic and concentrated, the EU negotiators are looking for a legal basis for a variety of sectors of EU-China cooperation, including sustainable development and areas related to China's political transition.

\footnotetext{
${ }^{61} \mathrm{Ibid}$

${ }^{62}$ Council of the European Union, "Ninth EU-China Summit, Helsinki 9 September 2006, Joint Statement," Press Release, 11 September 2006, $12642 / 06$ (Presse 249), accessed 16 February 2013, http://www.consilium.europa.eu/ueDocs/cms Data/docs/pressData/en/er/90951.pdf,

${ }^{63}$ Zhang Jiao. "The EU-China Relationship Arriving at a Bottleneck," 4

${ }^{64}$ Anonymous, Interview with Julie Pickering, May 2012, Brussels

${ }^{65}$ Zhang Jiao. "The EU-China Relationship Arriving at a Bottleneck," 4

${ }^{66}$ Ibid
} 
From this chapter, it is clear that formal EU-China relations have become more inclusive, extensive and intensive over the years. Today a number of problems in the relations are visible, and shifts in perceptions seen to have taken place with China's impressive economic rise and the EU's economic downturn. In looking at the way the EU constructs its relations with China, we may be able to identify areas of tension and cooperation between the two actors. Economic, geopolitical and even normative considerations are seemingly high on the agenda for the EU; an analysis of the narratives the EU uses to explain its actorness towards China may shed light on how these are treated, similarly or differently. 


\section{Chapter: Theoretical Contributions}

Theoretical contributions to the field of EU foreign policy are vast, encompassing the complexity of international relations theory more broadly. Nevertheless, the particular construct of the EU has encouraged, especially recently, the use of theories that stress the role of non-traditional sources of power and statehood, leading to recognition of the attractiveness of constructivist theory. In this work, a conventional constructivist approach to the study of the EU's action towards China will be applied, despite acknowledging the existence, even possible predominance, of realpolitik tendencies at the member state-level possibly explicated by rationalist theories. Furthermore, an argument is made that the $\mathrm{EU}$ is itself acting in a constructivist manner.

The constructivist school is by no means unified, but is nevertheless guided by specific principles, foremost of which in IR theory is the belief that actions cannot be entirely explained by rationalist, exogenously-dictated interests. Rather, identity, norms and values all play a 'constitutive role' in making foreign/domestic policy and shaping actors and structures. ${ }^{1}$ The interaction of these constitutive factors can lead to some change, and through socialization, interact and converge through communicative and discursive practices. ${ }^{2}$ For early theorists like John Ruggie, Richard Ashley, and Alexander Wendt, international politics are 'constructed' through ideas/culture/identities, which are said to be iterative.

\footnotetext{
${ }^{1}$ Neill Nugent, The Government and Politics of the European Union, $7^{\text {th }}$ Edition (New York: Palgrave MacMillan, 2010): 442

${ }^{2}$ Giuseppe Balducci, "The Limits of Normative Power Europe in Asia: The Case of Human Rights in China," East Asia, 27 (2010): 39
} 
Both neo-realism and neo-liberalism/neo-liberal institutionalism typically work under the assumptions of fixed interests and fixed constraints on the choices of actors. ${ }^{3}$ For a theorist like Kenneth Waltz, the global systemic structure constrains the preferences and choices of the units, the most important of which in international relations are states. The interests of states naturally supersede any concern for norms and identities, and states are primarily concerned with the distribution of power in a world distinguished by anarchy (leading to the ensuing need for states to self-help). For neo-liberal theorists, states can converge and cooperate in the global structure through the use of institutions or treaties, and these theorists do see a role for norms and ideas in international affairs, though only in the sense that they can lead to inter-state cooperation. For constructivists, these two approaches ignore the constitutive role that norms, values, identities and ideas play in defining the interests of actors. ${ }^{4}$ By overlooking the ways in which the latter affect the social processes that themselves determine the meaning we attribute to the structure, constructivist authors argue that these traditional theorists would be unable to account for significant changes in the global structure, or within agents and their preferences.

The internationalization of norms forms an important part of the constructivist tradition. ${ }^{5}$ According to a constructivist reading, the EU's behavior in international affairs and international trade, in which it reveals its preference for norms, exposes a constitutive point of difference between itself and traditional great powers. It also reveals the beliefs and ideas of EU policy makers, and to a large extent, of the European public.

\footnotetext{
${ }^{3}$ John Baylis and Steve Smith, Eds., The Globalization of World Politics: An introduction to international relations, Third Edition, (Oxford: Oxford University Press, 2006), 252

${ }^{4}$ Ibid

${ }^{5}$ Op. cit., p. 253
} 
Wendt describes the agent-structure problem, positing that structures not only constrain but actually constitute and construct the identities and interests of the agent (states). ${ }^{6}$ These agents themselves also play a constitutive role vis-à-vis the structures, which they are able to recreate and even alter. There is nothing intrinsically 'natural' about the global structure, but rather, it is socially constructed. The way a state will respond to the structure is determined not only by materialism, but also in part by different identities and ideas. According to Wendt, in contrast to the neorealists, the structure and the agents can be affected by normative considerations. Hopf similarly proposes that "actors develop their relations with, and understandings of, others through the media of norms and practices" without which "exercises of power, or actions, would be devoid of meaning." Adler agrees, saying that "norms constitute social identities and give national interests their content and meaning. ${ }^{.8}$ Checkel argues that norms are "shared understandings that constitute actor identifies and interests." Schimmelfennig proposes constructivism's focus on the "primacy of ideational intersubjective structures," which are modified by, among other things, "causal or instrumental ideas (knowledge)" and "principle ideas (values, norms)."10

For March and Olsen, states may act according to the 'logic of appropriateness,' in which rational decisions by state actors are mediated by normative or ideational

\footnotetext{
${ }^{6}$ Alexander E. Wendt, "The Agent-Structure Problem in International Relations Theory," International Organization, 41:3 (Summer, 1987): 335-370

${ }^{7}$ Ted Hopf, "The Promise of Constructivism in International Relations Theory," International Security, 23:1 (Summer 1998): 173

${ }^{8}$ Haydon, "Human rights and the development of EU-China relations," 6

9 Jeffrey T. Checkel, "International Norms and Domestic Politics: Bridging the Rationalist-Constructivist

Divide," European Journal of International Relations, 3:4 (1997): 473

${ }^{10}$ Frank Schimmelfennig, "Constructivism and EU Studies," presentation at Comenius University, Bratislava, April 2008, accessed January 2013.

www.exu.sk/material/.../constructivism-and-EU-studies-Bratislava.ppt
} 
concerns- an awareness of the appropriateness of an action given the identity of the collective. ${ }^{11}$ This logic gives a primary role to norms and ideas in shaping policymaking. Other constructivists, such as Keck, Sikkink and Finnemore, have highlighted the role of non-traditional actors, such as NGOs and international organizations, in shaping political decisions in their own right, something generally unacknowledged by rationalist schools. They may play the role of 'norm entrepreneurs,' persuading traditional state actors to adopt certain positions based on normative considerations. ${ }^{12}$

In his contribution to social constructivist readings of European integration, Checkel proposed that the concept on socialization- or social learning- was integral to understanding how actors or agents secure new preferences. He suggested that "social learning involves a process whereby actors, through interaction with broader institutional contexts (norms or discursive structures), acquire new interests and preferences - in the absence of obvious material incentives." ${ }^{13}$ He has further suggested that socialization can both take place by international institutions, and also within institutional frameworks. ${ }^{14}$ The idea of socialization, explained by Checkel in the context of the EU, and used by many constructivist IR theorists more generally, may shed some light on the actions of the EU in their relations with China. It forms an important component of the idea of

\footnotetext{
"James G. March and Johan P. Olsen, "The logic of appropriateness," ARENA, Working Papers (September 2004): 3. Accessed March 2013, http://www.sv.uio.no/arena/english/research/publications/arena-publications/workingpapers/workingpapers2004/wp04 9.pdf

${ }_{2}^{2}$ Anne-Marie Slaughter, "International Relations, Principal Theories," in Max Planck Encyclopedia of Public International Law, Ed. R. Wolfrum (Oxford: Oxford University Press, 2011) Accessed March 2013. http://www.princeton.edu/ slaughtr/Articles/722 IntlRelPrincipalTheories Slaughter 20110509zG.pdf ${ }^{13}$ Jeffrey T. Checkel, "Social construction and integration," Journal of European Public Policy, 6:4 (1999): 548. Accessed February 2013, http://graduateinstitute.ch/webdav/site/political_science/shared/political science/7183/4th\%20week/Check el.pdf

${ }^{14}$ Jeffrey T. Checkel, "International Institutions and Socialization," ARENA Working Paper (April 1999) Accessed March 2013, http://www.sv.uio.no/arena/english/research/publications/arenapublications/workingpapers/working-papers 1999/wp99 5.htm
} 
engagement with third countries, particularly on issues in which the EU is seeking to share its best practices in the hope of securing some shift or change in policy, particularly within more normative or sensitive areas.

In European Union studies specifically, constructivism has made an important contribution, forming part of what is loosely referred to as the 'constructivist turn' in IR theory. ${ }^{15}$ As mentioned, constructivism seems particularly adept as a descriptive tool for the EU's foreign actorness, given that the EU itself seems to use this framework to describe its actorness, and utilizes the language of norms, ideas, and generally the use of power/force that is non-traditional. In the case of the EU's foreign actorness, one can see it acting in a constructivist manner by examining the image it promotes of itself. In its global endeavors, the EU projects an image of itself as a global actor with substantial contributory powers, and the EU perceives itself as something distinct with a generally positive image. ${ }^{16}$ Much of the literature on the EU's foreign actorness focuses on answering the question of its particular type of actorness, trying to investigate a perceived distinctiveness in the 'EU model' of foreign policy.

The EU also often acts in a constructivist self-reflexive manner in which it is on some level hyperconscious of its own place in the world. In its relations with China, one sees the EU constructing a vision of itself in the world and, simultaneously, its understanding of the world structure itself. Through discursive and communicative

\footnotetext{
${ }^{15}$ Jeffrey T. Checkel, "The Constructivist Turn in International Relations Theory," World Politics, 5:2 (1998): 324

${ }^{16}$ Hanns W. Maull, «The European Union as civilian power : aspirations, potential, achievements,» in USChina-EU Relations: Managing the new world order, Eds. Robert Ross, Øystein Tunsjø and Zhang Tuosheng (London: Routledge, 2010): 57
} 
practices, as well as the weight it places on norms and ideas, the EU is itself engaging in constructivist behavior.

Constructivism is best equipped to understand the EU's creation of specific narratives about its role in international affairs, attempts which on some level are aimed at disseminating the EU's socially-constructed and socially-informed 'meanings' into the global structure. These actions would, in an ideal environment, modify the ways in which actors external to the EU construct their worldviews, ultimately with the aim of having them construct them in a similar manner to the EU or favourable to it.

From the outset, the two narratives proposed in this work seem very different. The normative actorness narrative is about normative considerations- bettering the world- and suggests that the EU has much to teach others thanks to its own unique development. There is something exceedingly post-Westphalian about it, such as its treatment of universalistic norms and values unhindered by borders. ${ }^{17}$ The strategic partnership narrative, on the other hand, seems to be much more interest-focused, suggesting equality of partners and the preservation of the EU in an increasingly fragmented world order. A part of this narrative deals with creating actorness for the EU in global affairs that is suggestive of state-like actorness, and possibly of Westphalian-like ambitions. These differences may lead to questions of mutual incompatibility of the use of both narratives, or at the very least an inherent tension.

In the case of strategic partnerships, one can see a clear moment of constructed identity. In a socially constructed world, the EU has adopted a narrative to give itself power. In the face of strong member states and perceived shifts in the global system, the

\footnotetext{
${ }^{17}$ Ben Tonra, "Democratic foundations of EU foreign policy: narratives and the myth of EU exceptionalism," Journal of European Public Policy, 18:8 (December 2011): 1194
} 
EU has reacted by creating a structure that would provide it with some legitimacy from the member states and external actors. By bringing external policies on China under one 'banner' and engaging external actors in frequent high-level dialogues, the EU is given an actorness which it did not have before, creating the perception that Europe is speaking with a single-voice, with a single 'foreign minister' and that it is a legitimate actor in foreign affairs. ${ }^{18}$

The links between the normative discourse and constructivism are also very clear. Constructivism tends to draw attention to ideational factors in creating and altering the world structure, which is an inherent element of normative discourse. That norms, values, ideas and ideals would play a predominant role in the formulation of foreign policy and foreign actorness is then best understood using a constructivist framework, which acknowledge space for these factors to shape policy and decision-making. The EU would act normatively in foreign relations because this is a way in which it can modify the global structure in such a way that both suits its own interests and its normative concerns.

The concept of narratives, as utilized here, is multi-disciplinary and has become an important analytical tool in a wide-range of disciplines. ${ }^{19}$ Its theoretical roots are also varied, though constructivism is obviously a major influence, as are critical discourse analysis and sociological theories that discuss the constitutive role of identities and discourses- narrations. ${ }^{20}$ In political contexts, "narrative forms of thought and expression are based on stringing events together into chains" or about the way we "story the

\footnotetext{
${ }^{18}$ Renard, Thomas, Interview with Julie Pickering, May 2012, Brussels

${ }^{19}$ Shaul R. Shenhav, "Political Narratives and Political Reality," International Political Science Review, 27:3 (2006): 245

${ }^{20}$ Bernhard Forchtner and Christoffer Kølvraa, "Narrating a 'new Europe"': From 'bitter past' to selfrighteousness?" Discourse \& Society, 23:4 (2012): 379
} 
world." ${ }^{21}$ They are considered a tool through which people can understand and constitute identities and "make sense of the social world" and "from which inferences can be drawn." 22 They bring together "events or discourses that might otherwise seem unconnected to the public." ${ }^{23}$ In the EU, narratives form an important part of the discourse; the EU often sets out its vision for the world in this manner. ${ }^{24}$ Still, because the EU integration project is relatively young, the narration efforts are incipient, particularly in a relatively new policy area like foreign policy. What has emerged so far is a broad narrative of the EU integration project apropos its own war-time past and its success in essentially 'overcoming' the traps of the traditional nation-state system, what Ben Tonra has called the EU's 'narrative of exceptionalism.' The narrative is accompanied by specific tropes, which at the EU level include references to being a sui generis entity, post-Westphalianism/post-modernism, and of course, normative concerns. ${ }^{25}$ There are competing narratives at the member state level, which may interact with these and even challenge them, as was on display during the 2005 Constitutional Treaty debates. That is important to maintain: the narratives are very elites-driven projects, often supported by academic works but not necessarily by the European public. ${ }^{26}$

These narratives remain at the discourse level. In practice, the EU often acts according to a number of logics, and sometimes appears, particularly at the level of the member states, to be an ad hoc, pragmatic actor in international affairs. Even if treating the EU as a single entity, as is done here, an examination of these narratives in practice

\footnotetext{
${ }^{21}$ Shenhav, "Political Narratives and Political Reality," 246

${ }^{22}$ Forchtner and Kølvraa, "Narrating a 'new Europe'," 382; Per M. Norheim-Martinsen, "EU Strategic Culture: When the Means Becomes the End," Contemporary Security Policy, 32:3 (December 2011): 520

${ }^{23}$ Tonra, "Democratic foundations of EU foreign policy,"1194

${ }^{24}$ Forchtner and Kølvraa, "Narrating a "new Europe'," 379

${ }^{25}$ Tonra, "Democratic foundations of EU foreign policy,"1197

${ }^{26}$ Op. cit., 1190, 1992
} 
and in implementation displays the ambiguities in its narrative and the difficulties associated with both instrumentalizing them and achieving power in doing so. That is why both of the narratives examined here will be treated first at the discourse level, and only secondly at the level of implementation.

One question to consider in starting is whether global politics themselves have shifted, or whether the global order is still dictated in terms of military prowess. A strong case can be made that the type of distinct, liberal internationalist philosophy that is seen in the EU's narratives is the product of a qualitative shift in global politics. A new world order, à la Fukuyama, may have indeed emerged in the post-Cold War era, as demonstrated primarily by the entrenchment and embeddedness of multilateral institutions, the use of public international law and the reduction (in quantity and damage) of traditional inter-state warfare. Or perhaps the system has shifted in favour of democratization of world affairs through the (re)-emergence of great powers in South America, Eastern Europe, Africa and Asia, or the Global South, often referred to as the BRICS (or some variation of that), whose interests revolve around defending state sovereignty in a multipolar world. ${ }^{27}$ Both trends require the EU, removed of immediate traditional power, to legitimize or solidify its role in global affairs. Through the formulation of its foreign policy, the EU then has a tremendous opportunity to make itself a relevant global actor constructed in the image that it wants. This process must be viewed as a dual one: it is both a process of taking stock/ understanding its role in world affairs, as well a process of 'acting itself into being,' i.e., of creating the conditions necessary for the EU to become a more active global actor.

${ }^{27}$ Laïdi, "BRICS," 614 
One way in which the EU can legitimize its position in the world is through a selfreflexive exercise in which it 'takes stock' of its capabilities. Along with its impressive market size, the EU does play an important role in international affairs in certain policy fields and geographical regions. On issues of development and aid, trade policy and sustainable development, among others, the EU is viewed as a serious policy actor by both third countries and within international institutions. Likewise, the EU is thought to have significant sway over its neighbouring countries, in particular Eastern and Southeastern Europe. A part of the self-reflexive exercise has been to take note of the EU's relative strengths and weaknesses in the system, and try to exercise those areas in which it has a comparative advantage. This is reflected in the EU's strategic partnership narrative.

Another part of this exercise has involved conceptualizing the particular nature of the EU's global actorness. A great deal of academic literature been dedicated to analyzing the type of actor the EU represents in international affairs, expanding on ideas of the EU's civilian, normative and soft power. This literature, and its critiques, recognize that the EU is a sui generis entity; despite the plethora of views on this matter, the mainstream opinion is that the EU is neither a traditional international institution, nor does it a resemble a Westphalian state. In this sense, the unique construct of the EU- what it is- is thought to have an impact on its capacity to act in international affairs. Due to limited pooling and sharing capacities on defence issues, the EU cannot at this present time act as a serious military or hard power. Rather, the EU's power in global affairs is something rather distinct, which is reflected in the EU's normative actor narrative and economic power. In its relations with China, the EU demonstrates the process by which it is 
undergoing this last exercise. The narratives of a strategic partnership and of normative actorness form part of these concerted efforts. 


\section{Chapter: The Narrative of the Strategic Partnership}

\subsection{The narrative of the strategic partnership}

The concept of strategic partnerships has been used by the European Union over the past decade, and it views these as an essential component of its external relations. ${ }^{1}$ The European Security Strategy of 2003 played a crucial role in formulating the EU's strategic policies, presenting the EU as an increasingly "credible and effective actor,"2 which required the identification of these partnerships, of which there are today ten. Its publication can be viewed as an attempt by the EU to give itself a strategy and strategic actorness, and as a broader attempt to make the EU a strategic actor in foreign affairs. ${ }^{3}$ Prepared under the direction of then High Representative Javier Solana, it was a moment of the EU taking the initiative to discuss strategy- to attempt to formulate a long-term vision for itself, and move away from ad hoc responses to global events. ${ }^{4}$ The document was holistic in its vision of a world order, and focused a great deal on securing interests and the promotion of global public goods. The 2008 Report on the Implementation of the European Security Strategy (RIESS) confirmed that strategic partnerships were an integral way for the EU to achieve the stated objective of effective multilateralism saying, "the ESS called for Europe to contribute to a more effective multilateral order around the

\footnotetext{
${ }^{1}$ Maull, «The European Union as civilian power, » 58

${ }^{2}$ A Secure Europe in a Better World: European Security Strategy, 1

${ }^{3}$ Thomas Renard, "The EU Strategic Partnerships Review: Ten Guiding Principles," European Strategic Partnerships Observatory, Policy brief, 2. (April 2012):4. Accessed March 2013. http://www.egmontinstitute.be/papers/12/sec-gov/ESPO PB 2 TenPrinciples FINAL.pdf ${ }^{4}$ Jo Coelmont, "An EU Security Strategy: An Attractive Narrative," Egmont Security Policy Brief, 34. (March 2012): 3-4.
} 
world. Since 2003, we have strengthened our partnerships in pursuit of that objective."5 The EU would not only engage other countries, it would attempt to play a leading role in international affairs, by acting as "a force for a fairer, safer and more united world" and "leading to a renewal of the multilateral order."

A special Council meeting in September 2010 was organized by President of the European Council Van Rompuy to discuss these partnerships, where it was decided that strategic partnerships "provide a useful instrument for pursuing European objectives and interests... the full participation of emerging economies in the international system should allow its benefits to be spread in a balanced manner and its responsibilities to be shared evenly."7 At the EU-South Africa Summit in Brussels that same month, Van Rompuy said of these, "we agree on the need for Europe to promote its interests and values in a spirit of reciprocity and mutual benefit. The EU's strategic partnerships with key players in the world...provide a useful instrument for pursuing these objectives." ${ }^{\prime 8}$

At a meeting on the EU's engagement with the BRIC countries in February 2012, High Representative Ashton proposed that "it is incredibly important that we invest in our relationship with these countries, and are active and creative in our engagement with them. We have got a lot in common and potentially a lot that we can do together."9

\footnotetext{
${ }^{5}$ European Council, Report on the Implementation of the European Security Strategy-Providing Security in a Changing World, December 11, 2008, OJ S407/08: 11, accessed 20 February, 2013, http://www.consilium.europa.eu/ueDocs/cms Data/docs/pressdata/EN/reports/104630.pdf ${ }^{6}$ Op. cit., 2, 12

${ }^{7}$ European Council, European Council, 16 September 2010 Conclusions, 12 October, 2010. EUCO 21/1/10, REV 1, CO EUR 16/CONCL 3. Accessed March 2013. http://www.consilium.europa.eu/uedocs/cms data/docs/pressdata/en/ec/116547.pdf ${ }^{8}$ Laursen, "The EU's Strategic Partnerships"; European Union External Action, "Remarks by EU Council President Van Rompuy following EU-South Africa Summit," http://www.euun.europa.eu/articles/es/article 10129 es.htm

${ }^{9}$ European Union, Press Release, "Catherine Ashton, EU High Representative for Foreign Affairs and Security Policy and Vice President of the European Commission: Speech on EU foreign policy towards the
} 
China and the EU have both proclaimed that they are engaged in a strategic partnership. ${ }^{10}$ The aforementioned ESS of 2003 identified China as one of its possible strategic partners. ${ }^{11}$ The Chinese also identified the EU as a strategic partner in their $E U$ Policy Paper of the same year. A joint press statement after the $5^{\text {th }}$ EU-China Summit in October 2003 concluded that "the expanded intensity and scope and the multi-layered structure of China-EU relations...(is)... an indicator of the increasing maturity and growing strategic nature of the partnership."12 EU-China Summits have also provided clear discursive 'moments' in which the strategic partnerships are presented. In 2006 in Helsinki, a joint statement explained that "the strengthening of the relationship had been of great value to the long-term interests of the EU and China... as well as to peace, stability, and development in the world at large." ${ }^{.13}$ High-level political dialogue and consultations would, they claimed, promote "understanding and trust, expanding common ground, and advancing bilateral relations.",14

At the celebration of 35 years of EU-China relations in April 2010, Barroso said that the EU-China partnership has "been a stimulus for progress and a source of economic opportunities. These benefits are a result of good relations between leaders ...

BRICS and other emerging powers," 1 February 2012, Speech/12/56/ Accessed March 2013. http://europa.eu/rapid/press-release_SPEECH-12-56 en.htm

${ }^{10}$ Odgaard and Biscop, "The EU and China: Partners in Effective Multilateralism?" 54; David Shambaugh, "China eyes Europe in the world: Real convergence or cognitive dissonance?" in China-Europe Relations: Perceptions, policies and prospects, Eds. David Shambaugh, Eberhard Sandschneider and Zhou Hong (London: Routledge, 2008): 135; Volker Stanzel, "The EU and China in the global system," in China-Europe Relations: Perceptions, policies and prospects, Eds. David Shambaugh, Eberhard Sandschneider and Zhou Hong (London: Routledge, 2008): 254

${ }^{11}$ Norheim-Martinsen "EU Strategic Culture," 526

${ }^{12}$ Jonathan Holslag, "The Elusive Axis: Assessing the EU-China Strategic Partnership," Journal of Common Market Studies, 49:2 (2011): 296,

${ }^{13}$ Council of the European Union, Press Release, "Ninth EU-China Summit, Helsinki 9 September 2006, Joint Statement," 12642/06 (Presse 249): 1. Accessed 16 February 2013 http://www.consilium.europa.eu/ueDocs/cms_Data/docs/pressData/en/er/90951.pdf ${ }^{14}$ Ibid 
and chanelled through institutional mechanisms like our annual Summits and other dialogues." 15 He went on to say that the relations depend on "mutual understanding" and "complementarity," and that the two actors' "overall strategic economic objectives overlap." 16 The EU and China's partnership, he said, is based on "reciprocity," which is the "third key principle of EU/China relations, alongside mutual understanding and complementarity." ${ }^{17}$ As well, this partnership must go beyond bilateral cooperation, requiring both actors to "work together in a globalized world." 18

Van Rompuy echoed this in October 2010, claiming that both actors needed to "move this relationship forward in the years to come," and that their strategic partnership is of "utmost importance." He identified that both the EU and China are "major players in the world and therefore naturally share outlook and concern on many issues." 19 At the $13^{\text {th }}$ EU-China Summit that same month, a joint press communique outlined that the two "agreed to strengthen further their comprehensive strategic partnership in a spirit of equality, reciprocity and mutual benefit.",20

Taken together, these moments provide the basis of a narrative. The concept of strategic partnerships, and the tropes or features that constitute it, are brought up regularly, as are references to specific features of EU-China relations. While the EU does

\footnotetext{
${ }^{15}$ European Union, “Jose Manuel Durão Barroso, President of the European Commission: Peoples of yesterday, peoples of tomorrow: 35 years of EU/China relations," 30 April, 2010, Speech/10/199, 2. Accessed October 2012, http://europa.eu/rapid/press-release SPEECH-10-199 en.htm

${ }^{16}$ Op. cit., 3

${ }^{17}$ Ibid

18 Ibid

${ }^{19}$ European Council, Press Release, "Introductory remarks by Herman Van Rompuy, President of the European Council at the EU-China Summit," October 6, 2010, PCE 209/10, 1. Accessed October 2012. http://eeas.europa.eu/china/summit/summit_docs/20120920 hvr_opening remarks en.pdf

${ }^{20}$ European Council, Press Release, "13 $3^{\text {th }}$ EU-China Summit Joint Press Communiqué," October 6, 2010, 14577/10 Presse (267), 1. Accessed October 2012. http://www.consilium.europa.eu/uedocs/cmsUpload/116908.pdf
} 
discursively refer to the concept of strategic partnerships, the narrative around them is perhaps best thought of as incipient; the narrative is emerging, though it is not yet fully employed in a completely self-confident manner. The publication of the ESS was a serious attempt at fashioning a narrative of the EU as a strategic actor. While the crises in Yugoslavia in the 1990s created impetus for the formulation of new instruments, such as the Common Security and Defence Policy (CSDP) and CFSP, there was acknowledgment within the EU of the need for a new narrative to accompany these developments. This would play the function of replacing the "attractive story of a Union that renders war within Europe impossible," replacing it with a narrative about how the EU would act in a "new world" in a strategic manner. ${ }^{21}$ So, the narrative of strategic actorness, in which the narrative of strategic partnerships is rooted, provide the EU as a strong, united and efficacious actor.

Even at the discourse level, however, a great deal of ambiguity remains about the use of the term strategic partnership. Despite its apparent rigueur in EU foreign policy circles, the term has yet to be properly defined, its content explained or the exact criteria for selection established. ${ }^{22}$ With some exceptions, the Commission has been unable to clearly explain exactly what the concept of strategic partnerships entails, and commentators on these partnerships, by and large, accept that it is still being fashioned. ${ }^{23}$ It is unclear, for example, what the ten strategic partners have in common, and whether they are treated equally. Some, like Canada, the United States, and Japan, are advanced

\footnotetext{
${ }^{21}$ Coelmont, "An EU Security Strategy," 2

${ }^{22}$ Susanne Gratius, "The EU and the 'special ten': deepening or widening Strategic Partnerships?" FRIDE Policy Brief, 76 (June 2011): 1, accessed January 2013, http://www.jamestown.org/single/?no cache $=1$ \&tx ttnews $\% 5 B t t$ news $\% 5 \mathrm{D}=3631$

${ }^{23}$ Mattlin, «Thinking Clearly on Political Strategy, » 117
} 
economies that share similar value-systems, often leading to common positions in international affairs. Others, like South Korea and Mexico, are important economies, but they are certainly not regional leaders or necessarily of strategic value to the EU. There are also the emerging markets, such as China and India, which are in many ways still developing economies facing very real challenges, yet also regional and possibly global hegemons, entailing a separate set of challenges. Russia is the only strategic partner that can be said to be in the EU 'neighbourhood,' which possibly necessitates a distinct relationship. Overall, there is a great deal of doubt that the emerging economies converge with the EU on important matters in multilateral fora, as seen in the Copenhagen Summit on climate change. ${ }^{24}$

The real trouble with the term as applied here is that it is not clear what unites these ten countries, even whether they are 'strategic' or just 'important' partners. ${ }^{25}$ Some, like China, are deeply interdependent with the EU, while others are not. Specifically looking at the EU-China strategic partnership, it is one of the best-developed strategic partnerships in terms of breadth and regularity of contact. However, serious concerns are raised about the substance of these contacts. Others question the validity of the claim of the strategic element of these relations, suggesting that they may rather be conceived of as intensive bilateral relations. ${ }^{26}$ This ambiguity may then be reflected in attempts at actualization or implementation of the narrative.

\footnotetext{
${ }^{24}$ Rosa Balfour, "EU Strategic Partnerships: are they worth the name?" European Policy Centre, Commentary, September 15, 2010, accessed January 2013. http://www.epc.eu/documents/uploads/pub 1145 eu_strategic partnerships are they worth the name.pdf

${ }^{23}$ Sven Biscop and Thomas Renard, "EU's strategic partnerships lack content," EUObserver.com, August 27, 2009, accessed May 2012, http://euobserver.com/opinion/28584

${ }^{26}$ Renard, "The EU Strategic Partnerships Review," 1-2
} 
As seen, the literature on the strategic partnership, as well as the discourse used by both Brussels and Beijing, suggests that this concept is very much still being developed. ${ }^{27}$ Many of the experts interviewed by this author provided similar accounts regarding either the confusion surrounding the term or the lack of any strategy at all, or both, which relates to broader uncertainty about the strategic partnerships.

The narrative is therefore best viewed as an incipient one, rooted in a broader narrative about the EU being a strong and united actor in international affairs. The narrative revolves around discursive 'moments' when the EU presents itself as such a capable actor vis-à-vis external partners.

\subsection{Analytic features of the narrative}

The last section has established that the EU creates and reiterates the discourse of strategic partnerships, in doing so creating a narrative. In analyzing this discourse, as well as secondary literature on the strategic partnerships and EU-China relations, key analytic features can be extracted, which would help us understand the narrative and appreciate when to recognize it. It has been suggested that a problem exists in understanding the strategic partnerships as a broad strategic narrative, given that no single set of criteria or template exists in order to judge its use. Nevertheless, in conceptualizing and 'unpacking' the strategic partnership as it is applied to China, six analytic features can be isolated that provide a descriptive analysis of its content. These act either as markers of particular intentions behind the narrative, or else specific tropes that emerge from the EU's own

\footnotetext{
${ }^{27}$ Jing Men and Giuseppe Balducci. "EU-China Relations in the 21st Century," in Prospects and Challenges for EU-China Relations in the 21st Century: The Partnership and Cooperation Agreement, Eds. Jing Men and Giuseppe Balducci (Pieterlen: Switzerland: Peter Lang Publishing Group, 2010): 22
} 
discourse. Overall, they provide an opportunity to analyze the narrative more broadly by detailing specific features. These are: the narrative is a legitimation exercise for the EU; it is an instrument/tool for organizing EU-China relations; it suggests mutual understanding; it is based on equality of partners; it should be interest-based; and there is an aspirational quality or long-term view to them. In the following section, each criterion will be analyzed broadly, and specifically as it relates to China.

1. Legitimation exercise for the EU: The concept of strategic partnerships provides the EU with a set of instruments and a powerful narrative, which allows it to become, at least in its own eyes, a legitimate player in foreign affairs- an actor. This can be seen as a highly-constructivist attempt by the EU to 'act itself into being' or 'act itself into existence.' If it creates the institutions and offices of a state, along with delegation presence across the world, then, the thinking goes, it will be treated like a respectable global actor. This exercise is then a strategic and planned attempt at self-legitimation by, among other things, institutionalizing comprehensive relations with external actors. ${ }^{28}$

As a horizontal foreign policy tool, the EU's strategic partnerships may have emerged as a response to perceived global systemic change. The political fallout in Europe caused by the Iraq War led to major rethinking of Europe's transatlantic ties, and fed into and further fuelled a preexisting debate on Europe's role in world affairs, which included rhetoric about the region's relative decline in the face of rising multipolarity. ${ }^{29}$ Having fallen into obscurity after its initial introduction, the concept of strategic partnerships was reignited by the Lisbon Treaty and the renewed focus on the EU's role in external affairs, seen clearly in the creation of a new EEAS and the general push for a

\footnotetext{
${ }^{28}$ Norheim-Martinsen, "EU Strategic Culture," 521

${ }^{29}$ Renard, Thomas, Interview with Julie Pickering, May 2012, Brussels
} 
more unified and professionalized European diplomatic corps. ${ }^{30}$ Barroso spoke of this in the context of the EU's strategic partnership with China, claiming in 2010 that "the demand for Europe to engage globally is huge. The Lisbon Treaty gives the European Union the chance to do this." ${ }^{31}$ Also in 2010, a Council meeting confirmed that "in accordance with the Lisbon Treaty... the European Union and its member states will act more strategically... require a clear identification of its strategic interests and objectives. ${ }^{, 32}$ A 2011 report on the CFSP identified that one of main tasks of the EEAS is to "support the High Representative in fulfilling her mandate, making full use of the potential of the Treaty of Lisbon to promote increased coherence of EU external action." 33

The treaty also witnessed the creation of two positions that could act as the public face of the EU in global affairs: possibly the answer to Henry Kissinger's famous question of who to call in Europe. First and foremost is the 'double-hatted' position of High Representative for Foreign Affairs and Security Policy and Vice-President of the European Commission. Baroness Catherine Ashton has been selected to play a leading role in the EU's external actions and foreign policies in her new capacity, and it has been suggested that strategic partnerships were a tool for her to use as a sort of branding campaign, both for herself and her new functions. ${ }^{34}$ The EEAS, more broadly, helps contribute to the development of an independent "strategic vision" for the EU, acting as a

\footnotetext{
${ }^{30}$ Renard, "The EU Strategic Partnerships Review," 2

31 "Peoples of yesterday, peoples of tomorrow: 35 years of EU/China relations," 4

${ }^{32}$ European Council, 16 September 2010 Conclusions, 2

${ }^{33}$ Council of the European Union, Main aspects and basis choices of the CFSP (point G, paragraph 43 of the Interinstitutional Agreement of 17 May 2006) - 2011- Annual report from the High Representative of the European Union for Foreign Affairs and Security Policy to the European Parliament, 9 October, 2012, 14605/1/12 REV 1, PESC 1195 FI 724, 4. Accessed February 2013, http://register.consilium.europa.eu/pdf/en/12/st14/st14605-re01.en12.pdf

${ }^{34}$ Renard, Thomas, Interview with Julie Pickering, May 2012, Brussels
} 
'foreign ministry. ${ }^{35}$ The creation of a permanent president of the European Council, for which Hermann Van Rompuy was selected, was also partly motivated by desires for public face and continuity in the EU's external representation. The Lisbon Treaty establishes that the President of the Council and High Representative must work together to represent the EU and implement actions to achieve foreign policy objectives. ${ }^{36}$ It is within this post-Lisbon context of new institutions and actors that strategic partnerships (re-)emerge as a concept in official EU documents in $2010 .{ }^{37}$ The RIESS, for example, proposes that the EU's "capacity to address the challenges has evolved... we must strengthen our coherence through better institutional coordination and more strategic decision-making. The provisions of the Lisbon Treaty provide a framework to achieve this. ${ }^{38}$

Within the context of the creation of a broad narrative of strategic thinking, the strategic partnership 'story' provides the EU with a way of legitimizing its foreign actorness vis-à-vis other entities- of relationally imbuing it with strategy. Rather than attempt to compete with the emerging powers (which it cannot), or turn to the United States, this approach sees cooperation and engagement as a way for the EU to remain relevant in an increasingly fragmented world. ${ }^{39}$

Providing a narrative for global engagement with external actors at the EU level also allows it to gain legitimation from the member states. The publication of the ESS

\footnotetext{
${ }^{35}$ David Allen and Michael Smith, "The EU, Strategic Diplomacy and the BRIC Countries," Jean Monnet Multilateral Research Network, Policy Paper, 11 (February 2012): 3

${ }^{36}$ Op. cit., 4

${ }^{37}$ Laursen, "The EU's Strategic Partnerships"; Giovanni Grevi, Ed. Mapping EU Strategic Partnerships, 4. (FRIDE Publication: 2011), accessed February 2013, http://www.fride.org/publication/956/mapping-eustrategic-partnerships

${ }^{38}$ Report on the Implementation of the European Security Strategy, 9

${ }^{39}$ Renard, "The EU Strategic Partnerships Review," 4
} 
imbues the EU with a strategic actorness around which the member states and institutions can gather. ${ }^{40}$ The ESS even acknowledges this important function, claiming that it the EU needed "a system that combines the resources of member states with those of EU institutions," and called for "greater coherence. ${ }^{, 41}$ Viewed, for example, as an attempt to 'sell' the CSDP, the ESS is promoting the EU's 'state-like' qualities, and a narrative around which the member states can themselves view the EU as a legitimate actor, to which they 'upload' certain policy-making powers. ${ }^{42}$ Links and complementarities between the latter document and the American National Security Strategy of 2002 have been referenced by many authors, suggesting the state-like qualities of the ESS and the functions it attempts to perform. ${ }^{43}$

The EU's constructivist approach to its global actorness is striking in the analysis of the strategic partnerships, by which each sees in the relationship with the other an image of itself, or of the kind of global actor it wants to be. To the EU, legitimation by an external party through an arrangement like the strategic partnership allows it to achieve, at least conceptually, membership in an exclusive club of world powers. It can then play a role in constructing and shaping the world order in a way that suits its own interests, what Jacoby and Meunier have called the "management of globalization." ${ }^{, 44}$ For these reasons, the narrative, and the post-Lisbon institutional changes, can be viewed as ways in which the EU can act increasingly like a traditional state actor. The narrative would help it appear unified, cohesive and as the name suggests, strategic. Despite the rhetoric

\footnotetext{
${ }^{40}$ Norheim-Martinsen, "EU Strategic Culture," 517

${ }^{41}$ Report on the Implementation of the European Security Strategy, 12-13

${ }^{42}$ Norheim-Martinsen, "EU Strategic Culture," 521

${ }^{43}$ Op. cit., 518,523

${ }^{44}$ Wade Jacoby and Sophie Meunier, "Europe and the management of globalization," Journal of European Public Policy, 17: 3 (April 2010): 299
} 
on multilateralism and global goods, the narrative forms part of a broader exercise of making the EU-level more state-like, as seen in its attempts to gain speaking rights at the UN. ${ }^{45}$ This kind of behavior is perhaps necessary in the face of multipolarization, which would require the EU to ground its norms in a more "traditional state-like milieu.",46 This function of the narrative would be recognizable in its implementation through the use of discourse and language by the EU that is suggestive of its efficacious actorness in foreign affairs.

2. An instrument/ tool for organizing EU-China relations: Strategic partnerships are also a way of organizing the EU's foreign relations. They can be viewed as an instrument for the EU, an umbrella framework under which the EU can arrange sets of dialogues, summits, working groups and various institutions that overall represent a multi-vectored and varied relationship with countries thought to bear significant importance in international affairs. Summits, for example, can be seen as an integral part of actualizing the strategic partnership narrative in a timely, coordinated fashion. The EU leaders view these as providing "strategic guidance" to the relations. ${ }^{47}$ Others have even suggested that carrying through with institutionalized summits with external partners may forcibly instill the EU with strategy. ${ }^{48}$

Another element of this dimension is that strategic partnerships are a way for EU institutions to provide coherence to external policy in a 'post-pillar' EU. The Lisbon Treaty officially did away with the three-pillar system, and the strategic partnerships

\footnotetext{
${ }^{45}$ Tonra, "Democratic foundations of EU foreign policy," 1194

${ }^{46}$ Daniel Fiott, "The European Union's Normative Power in a Multipolar World," (paper presented at the EUSA Biennial Conference 2011, Boston, United States, March 3-5 2011): 11

${ }^{47}$ European Council, " $13^{\text {th }}$ EU-China Summit Joint Press Communiqué," 1

${ }^{48}$ Allen and Smith, "The EU, Strategic Diplomacy and the BRIC Countries," 6
} 
provide a replacing framework within which to organize external relations and justify coordination of different offices and institutions working on external matters. ${ }^{49}$ The narrative then becomes a way to explain to 'Eurocrats' the future of EU foreign policy. It is something around which they can all unite and which would also provide legitimation to the treaty mandate of uniting under the CFSP, rather than remaining in silos. ${ }^{50}$ The use of the strategic partnership as a tool or instrument would be recognized through the use of institutionalized spaces and venues, such as summits, dialogues and working groups. These attempt to bring together not only the Chinese and Europeans, but also frequently groups from different EU institutions.

3. Mutual understanding: There is a certain degree of mutual understanding about the general layout of world affairs suggested in this narrative. This would be based either on mutual understanding emerging from common approaches or mutual understanding and respect for the partners' own goals. These partnerships can be seen as institutionalizing engagement based on "like-mindedness between pivotal players" or willingness to institutionalize partnerships "in an increasingly competitive global market of ideas." ${ }^{\text {51 }}$ In the case of the EU-China strategic partnership, a joint communique affirmed the idea of mutual understanding at the most recent summit in September 2012, with both partners emphasizing "the importance of taking a positive view of each other's development and rendering mutual support. The Chinese side reaffirmed its continued support for the European integration process, and expressed confidence that appropriate steps were being taken to tackle the euro area sovereign debt crisis. The EU reaffirmed its support for

\footnotetext{
${ }^{49}$ Renard, Thomas, Interview with Julie Pickering, May 2012 Brussels

${ }^{50} \mathrm{Ibid}$

${ }^{51}$ Grevi, Mapping EU Strategic Partnerships, 4
} 
China's peaceful development and its respect for China's sovereignty and territorial integrity and expressed its confidence in China's efforts to maintain sustainable, steady and rapid economic growth." 52

Despite the promotion of variant political and social norms, the EU and China do converge in their belief systems on some issues and policy areas. As seen, both publicly support a greater plurality in international affairs: Europe typically tends to use the term 'multilateralism', while China refers to 'multipolarity,' with which it has long been preoccupied. ${ }^{53}$ However, the multipolarity it advocates is likely different from the multilateralism advocated by the EU. ${ }^{54}$

The idea of convergence is central to studies of the EU-China strategic partnership and the narrative, relating to the idea of mutual understanding between the two actors. Documents highlight that a strategic partnership has emerged out of, or seeks to better organize, joint cooperation on specific issues, and at the discourse level, these two actors are said to converge on a number of areas of a global and bilateral nature. Both actors speak of needing to "address together global challenges" and welcome "the fact that relations had progressed beyond the bilateral framework and taken on a global dimension." ${ }^{\text {} 5}$ This relates to the EU using the narrative as a legitimation tool; it highlights key areas on which the two actors can cooperate, thus establishing itself as a serious actor capable of tackling the world's problems. Cooperation on global issues is aided, according to both sides, by the fact that there is no direct source of conflict

\footnotetext{
52 "Joint Press Communiqué, $15^{\text {th }}$ EU-China Summit," 2

${ }^{53}$ Haydon, "Human rights and the development of EU-China relations," 16

${ }^{54}$ Men and Balducci, "EU-China Relations in the 21 st Century," 26

${ }^{55}$ European Council, Press Release, “Opening remarks by President of the European Council Herman Van Rompuy at the $15^{\text {th }}$ EU-China Summit," September 20, 2012, EUCO 171/12 (Presse 387). Accessed October 2012. http://europa.eu/rapid/press-release PRES-12-387 en.htm ;"Joint Press Communiqué, $15^{\text {th }}$ EU-China Summit," 1
} 
between them. ${ }^{56}$ In fact, Zhang has even asserted that the use of the word 'strategic' in this relationship may simply refer to the absence of any major source of conflict between the two of them. ${ }^{57}$ Others have proposed that strategic refers to the "comprehensive" nature of the relationship, which has expanded outside of purely bilateral issues. ${ }^{58}$ Both sides officially agree to work in a partnership to deal with problems of a global nature, including energy security, terrorism, sustainable development, climate change, food and water security, nuclear safety and environmental protection- all issues that can be considered strategic. ${ }^{59}$ Joint statements published after summits provide long lists of areas of joint concern or cooperation, highlighting that these were discussed and that both sides appreciate the importance of working with the other, which would allow us to recognize when this discourse is being used to support a broader narrative of the EU as a strategic actor.

4. Equality of partners: The strategic partnership discourse also suggests equality of partners. At the level of the narrative, two actors engaged in a strategic partnership are on equal-footing, and this should be operationalized in practice. In the case of EU-China relations, this means equality of actors in practice and spirit. In the event that differences in the relationship exist, "these should be discussed and handled in a spirit of mutual

\footnotetext{
${ }^{56}$ Mara Cairi, "The EU-China Relationship: From Cooperation to Strategic Partnership," in Ed. Federiga Bindi, The Foreign Policy of the European Union: Assessing Europe 's Role in the World (Washington, D.C.: Brookings Institution Press, 2010), 267

${ }^{57}$ Zhang Tiejun, " Sino-European Relations : From the Height to the Width. " In The Role of the European Union in Asia: China and India as Strategic Partners. Bart Gaens, Juha Jokela and Eija Limnell, Eds. (Surrey: Ashgate Publishing, 2009), 126

${ }^{38}$ Axel Berkofsky, "EU-China Relations- Really Towards a "Strategic Partnership"?" Sicherheit und Frieden, 4:3 (2006): 185, accessed March 2013, http://www.sicherheit-undfrieden.nomos.de/fileadmin/suf/doc/SuF 06 04.pdf

59 "Joint Press Communiqué, $15^{\text {th }}$ EU-China Summit," 1; Thomas Renard, "The EU Strategic Partnerships Review," 2
} 
respect and equality." ${ }^{60}$ This relates to the idea of reciprocity, highlighted by Van Rompuy as a key element of strategic partnerships, and specifically in the case of China. These concepts are mentioned throughout the discourse, but not expanded upon significantly. There are a variety of ways this could be actualized in practice, including through joint statements, which allow us to see when it is being utilized.

5. Interest-based: Achieving interests on both sides is viewed as an intrinsic part of the strategic partnerships. This may provide justification of why bilateral relations are organized in special partnerships: there is a great deal to gain from them, which might somehow merit a special instrument, strategy or conceptual distinction. As a tool or strategy it suggests that this is a good way- if not the best way- of achieving interests, economic or otherwise, on both sides. This is identified in the EU statements as the concept of 'complementarity' of interests, which describes a situation in which their "economies complement each other." ${ }^{, 1}$ Both actors have much to gain from the partnership, as stated in the 2006 Competition and Partnership document: "China's integration into the global trading and investment system has been beneficial for both Europe and for China." ${ }^{22}$ That the EU and China's economic relations are thought to be more complementary than competing is based on an understanding of different levels of economic development and different strengths of their economies. ${ }^{63}$ The idea of interestbased relations is found throughout $\mathrm{EU}$ press releases, which view the strategic

\footnotetext{
60 "Joint Press Communiqué, $15^{\text {th }}$ EU-China Summit," 2

61 "Peoples of yesterday, peoples of tomorrow: 35 years of EU/China relations," 3

${ }^{62}$ European Commission. Working Document Accompanying 'Closer Partners, Growing ResponsibilitiesA policy paper on EU-China trade and investment: Competition and Partnership. ' $\{\mathrm{COM}(2006) 631$ final.\} October 24, 2006. COM(2006) 632 final, 7, accessed February 8, 2013. http://trade.ec.europa.eu/doclib/docs/2006/october/tradoc 130791.pdf

${ }^{63}$ Dai Bingran,"Promoting Mutual Understanding- China perspective," in China-EU, A Common Future, Eds. Stanley Crossick and Etienne Reuter (Singapore: World Scientific Publishing Co., 2007): 253
} 
partnership as a "two-way street based on mutual interests and benefits." ${ }^{\text {"64 }}$ At the aforementioned EU-South African Summit in 2010, Van Rompuy made mention of the strategic partnerships as means for Europe to "promote its interests and values." In EUChina relations, a partnership should "meet both sides' interests." is a normative element to strategic partnerships, post-Lisbon it has been argued that their focus broadly has been much more on economic issues. ${ }^{66}$ This is acknowledged by some commentators, like Crossick, who argues that the partnership should "be based on mutual interests, but not necessarily on shared values. ${ }^{967}$ This part of the narrative would then be recognized both in the discourse and in the types of projects or initiatives begun by the two.

6. Aspirational relations and long-term view: The idea of systemic shifts is central to much of the EU's narrative. The most prominent theme in many academic works on the EU's foreign policy actorness is that, post-Cold War, new rules have been adopted by global actors. These systemic changes in the global order form a central component in the study of the EU-China relationship because the two actors discursively present the other, as well as their relationship, as having the potential to greatly impact world affairs (if it is not doing so already). In this sense, the strategic partnership is constructed as something that is aspirational in quality: long-term engagement will lead to more intensive and closer relations in the future, which will lead to both shifts in the global system and in a partnership that can help the two navigate the new system.

\footnotetext{
64 "The EU's Strategic Partnerships."; "Remarks by EU Council President."

${ }^{65}$ EU-China: Closer partners, growing responsibilities, 2

66 "The EU's Strategic Partnerships."

${ }^{67}$ Thomas Renard, Ed. EU-China: Building Upon a Dialogue Among Strategic Partners, Conference Report (Gent, Belgium: Academia Press, 2011), 6
} 
This relates to the role of 'grand strategy' present in both the EU and Chinese documents on the partnership. As Pascal Lamy said, "unlike in the United States- there is a much lesser sense of geopolitical challenge to Europe from China... we are happy to see... a greater diffusion of power, a more multi-polar world developing. ${ }^{.68}$ For some, "the relationship between China and the EU is being driven inexorably by geopolitical forces even more than economic ones. ${ }^{, 69}$ This is facilitated by the recognized lack of direct strategic conflict between the two actors in contrast to, for example, SinoAmerican relations, which are more securitized.

The strong notion of systemic vision that dominates much of the rhetoric in EUChina relations is seen on the EU side in the myriad of references to global shifts and multilateralism, especially in the ESS and the IIESS. $^{70}$ As seen, the EU and China tend to openly agree on their mutual support for multilateralism and the UN. It is also suggested that the Chinese government views the EU as an effective practitioner of multilateralism. ${ }^{71}$ Both share an appreciation for regional multilateral cooperation, along with traditional multilateralism and opposition to unilateralism. ${ }^{72}$ In many ways, its support for multilateralism may reflect the extent to which China has progressed in its acceptance of international norms, including those promoted by the EU. A strategic calculation would have been made by both sides, eager to see the other as an important

\footnotetext{
${ }^{68}$ European Union, Press Release, "Pascal Lamy EU Commissioner for Trade EU-China relations: continuity and change EU Chamber of Commerce in China Beijing," October 31 2003, Speech/03/503, accessed July 2012, http://europa.eu/rapid/press-release SPEECH-03-503 en.htm

${ }^{69}$ Ching, Frank. "Changing Dynamics in EU-China Arms Relations." China Brief, 4:5. (2004) Accessed March 2013, http://www.jamestown.org/single/?no cache $=1 \&$ tx ttnews\%5Btt news\%5D=3631

${ }^{70}$ Holslag, "The Elusive Axis," 299

${ }^{71}$ Shambaugh, David, "China eyes Europe in the world: Real convergence or cognitive dissonance?" 130

${ }^{72}$ Zhang Tiejun, «Sino-European Relations : From the Height to the Width,» 127 ; Gill and Murphy, China-Europe Relations, VIII
} 
partner in a rebalancing effort aimed at reducing American unilateralism. ${ }^{73}$ Regarding this claim, many have suggested that this reflects the aspirational element in EU-China relations, by which both see the other as important in their conceptions of world order. This is particularly true of the Chinese, who have long projected a desire for the EU to play a specific role as a pole. EU officials do not seem to have downplayed this, despite the significant problems this might raise in practice, primarily with respect to the continent's continued dependence on the US military.

The idea of an aspirational relationship is picked up in the secondary literature, with the authors suggesting that, despite some issues that need resolving, there is potential for a much stronger relationship in the future, projecting long-term engagement and possibly attempts at socialization. Zhang Tiejun, for example, supports this, writing that both sides are expecting a lot from each other, and he suggested that the best way for constructing a positive strategic partnership is to acknowledge the differences between the two parties and promote shared interests. ${ }^{74}$ Kerr and Liu see it as a major theme behind the strategic partnership. Despite asymmetries, they propose that China and the EU have enough symmetrical factors between them to develop a long-term positive relationship, and it is on this that they base much of their rhetoric. ${ }^{75}$ Gill and Murphy restate this theme, arguing that both sides have emphasized the future of this relationship. $^{76}$

\footnotetext{
${ }^{73}$ Haydon, "Human rights and the development of EU-China relations," 16

${ }^{74}$ Zhang Tiejun, « Sino-European Relations : From the Height to the Width,» 121

${ }^{75}$ David Kerr and Liu Fei, "Introduction," The International Politics of EU-China Relations, David Kerr and Liu Fei, Eds. (Oxford: Oxford University Press, 2007), 3

${ }^{76}$ Gill and Murphy, China-Europe Relations, IX
} 
The idea of China as a responsible stakeholder, more popular in Brussels than Washington, describes the process of its successful integration into the global multilateral structures, where it has proven to be more of a status quo power than a revisionist power. ${ }^{77}$ However, a constructivist process may also be at play here, in which China may be adapting the system to its own norms. As stated by Gustaaf Geeraerts, the Chinese are "becoming more influential, in the IMF, in the World Bank, in the UN, in the regional organizations, and of course, they have their own ideas and...they are more and more... conscious of their position and their willingness to adapt the system to their needs and interests... it's a kind of integration, but an integration which also has to at least be partly on their terms. ${ }^{, 78}$ Beijing has projected itself as a friendly power, viewing its role in the world as being one of holding "high the banner of peace, development and cooperation" and advocating its 'new security concept' and Five Principles of Peaceful Coexistence. ${ }^{79}$ China has promoted itself as a responsible power using multilateral/regional structures in its foreign relations. ${ }^{80}$ Beijing is very supportive of strengthening international security through the United Nations, and it is seen as the best organizations within which to practice multilateralism. ${ }^{81}$ While China could improve its payments to the UN, it actively contributes to its peacekeeping activities. ${ }^{82}$

\footnotetext{
${ }^{77}$ Renard, Thomas, Interview with Julie Pickering, May 2012, Brussels

${ }^{78}$ Geeraerts, Gustaaf, Interview with Julie Pickering, May 2012

${ }^{79}$ Zhang, Tuosheng, "On China's concept of the international security order," in US-China-EU Relations: Managing the new world order, Eds. Robert Ross, Øystein Tunsjø and Zhang Tuosheng (London: Routledge, 2010): 29

${ }^{80}$ Odgaard and Biscop, "The EU and China: Partners in Effective Multilateralism?" 67

${ }^{81}$ Zhang, Tuosheng, "On China's concept of the international security order," 35; Odgaard and Biscop, "The EU and China: Partners in Effective Multilateralism?" 72

${ }^{82}$ Bates Gill, "China's Evolving Approach to Multilateralism and Global Governance: Implications for the European Union," 144
} 
Beijing has, in many regards, accepted the rules of conduct based on a model of international relations as espoused by the EU. While the focus on state sovereignty and a Westphalian model of the nation differs tremendously from the EU's approach, China has been at the forefront of calls for democratization of international relations, by which it defends cultural pluralism and anti-hegemony ${ }^{83}$ This idea is certainly espoused by other emerging powers, particularly the so-called BRICS. It is also idea that has been promoted, albeit less aggressively, by Brussels, and in this we see a common aspirational vision shared by the two actors. A study of Beijing policy documents, in particular the 2003 paper on the EU, as well as the work of Chinese academics and statements by the Chinese leadership since the 1970s, indicates that the Chinese have often looked to Brussels as an important actor in its vision for a new world order. At the level of the narrative, the EU-China strategic partnership is presented as one that would allow for long-term engagement between these two actors, best handled in an institutionalized framework denoting its particular importance to both sides, beyond traditional bilateral relations. This feature would then be recognized in practice both in the discourse and in the types of projects engaged in by the two actors.

\subsection{Instrumentalization of the narrative}

It has been shown that the EU engages this narrative and uses discourse to support it. Key features of this narrative have been identified that would allow us to identify its key characteristics, and when it is being utilized. The question then becomes of how the EU instrumentalizes this narrative, and whether it corresponds to the reality of EU-China

\footnotetext{
${ }^{83}$ Jian Junbo, “A Clash of Civilization? Norms and Sino-EU Relations," International Review, Fourth (2008): 66,71
} 
relations. In other words, is the EU able to exercise this narrative effectively, or does it remain at the discourse level only? In analyzing this question, it is possible to distinguish ways in which the EU does instrumentalize this successfully, but also difficulties associated with any capacity to do so.

1. Legitimation exercise for the EU: The EU seems to use discursive representations of itself as a united actor in foreign affairs. The extent to which this is successfully instrumentalized is contentious, largely due to major ambiguities present within the EU. Why the EU needs to use the narrative as a legitimation exercise requires an understanding of the EU's approach to foreign/external relations. The EU's ability to operate as a single actor externally is most clearly impeded by the deeply rooted interest of its member states. A few larger members in particular are likely reticent to cede too much foreign-relations policy-making to the EU level, in particular the 'Big 3'- France, Germany, and Britain. ${ }^{84}$ As a result, external countries, it is argued, often contest the EU's actorness and its power in international relations. ${ }^{85}$ For example, one of the major problems from China's point of view is that the EU is not necessarily a cohesive and unitary actor. Beijing's willingness to play off member states against one another shows a deep understanding of the problems related to EU foreign policy. ${ }^{86}$ This reveals the competing interests of the EU's member states, many of whose national Chinese foreign policies are contradictory or competitive. France, Germany and the UK all compete on some level for China's attention, what a European Council on Foreign Relations report

\footnotetext{
${ }^{84}$ Kerr and Liu, "Introduction," 2

${ }^{85}$ Maull, « The European Union as civilian power, » 49

${ }^{86}$ Fox and Godement, A Power Audit of EU-China Relations, 3
} 
called their 'me-first strategy' towards China. ${ }^{87}$ This is complicated by the fact that France and the UK are on the UN Security Council, which may affect the EU's cohesiveness in that forum. ${ }^{88}$ In many ways, despite attempts by Brussels, there is no common European approach vis-à-vis China, which has allowed Beijing to 'divide and rule,' and play members off against each other. ${ }^{89}$

The recent economic downturn has also exacerbated the divisions within the EU, chiefly between industrialists and less industrialist countries, though this distinction is over-simplistic. The gloomy economic climate and resulting public discontent have created a sense of 'each-for-oneself' amongst the EU member states. In this climate, foreign investment is welcome, and politicians would be hard-pressed, or in any event more hard-pressed than before, to reject massive investment opportunities based on normative concerns, which can be perceived as out-of-touch with the concerns of the public and overly intellectualized. ${ }^{90}$ China has proactively sought out investment opportunities in many of the states worse affected by the crisis. The acquisition of the port in Piraeus in Greece in 2010, the purchase of BorsodChem chemicals in Hungary in 2011 and the sale of parts of Portugal's formerly state-owned energy company and state power grid in 2011 and 2012 are all examples of major Chinese investment in the member states, leading to worries of social dumping by Chinese companies and foreign ownership more generally. ${ }^{91}$ China has also been buying debt from these states, turning

\footnotetext{
${ }^{87}$ Op. cit., 28

${ }^{88}$ Federiga Bindi and Irina Angelescu, "Introduction," in Ed. Federiga Bindi, The Foreign Policy of the European Union: Assessing Europe's Role in the World. (Washington, D.C.: Brookings Institution Press, 2010): 2

${ }^{89}$ Fox and Godement, A Power Audit of EU-China Relations, 3

${ }^{90}$ Mattlin, "A Normative EU Policy Towards China," 14

${ }^{91}$ Ferry Batzoglou and Manfred Ertel, "Good Friends Are There to Help': Chinese Investors Take Advantage of Greek Crisis," Spiegel International, November 16, 2011, accessed February 10, 2013,
} 
out to often be a better choice than the IMF-ECB-EC troika. ${ }^{92}$ The situation resembles that of a classic prisoner's dilemma, in which the member states would benefit more when cooperating, but instead, each pursues unilateral action. ${ }^{93}$ Yet Beijing's actions are not purely strategic thinking on their part: it is said that China is extremely frustrated by the EU multi-governance system and institutional layout, and today has begun to invest more in the capitals. ${ }^{94}$

Many European member states have themselves turned to their national strategies in dealing with China. Given the importance of China in recent times, there is increasingly doubt in the member states that the EU is best equipped to handle these relations. ${ }^{95}$ This has been clearly witnessed in Poland's leading of the informal $16+1$ group, which is a meeting of Central and Eastern European countries with China based on economic and cultural cooperation. ${ }^{96}$ Relations between these countries with China, particularly Poland, have intensified in 2012, and China has reacted by proposing organizing a secretariat for the group, operating out of its Ministry of Foreign Affairs. ${ }^{97}$

http://www.spiegel.de/international/europe/good-friends-are-there-to-help-chinese-investors-takeadvantage-of-greek-crisis-a-797751.html; "Hungary-China sign dozen agreements during state visit," Budapest Business Journal, June 26, 2011, accessed February 10, 2013, $\mathrm{http}: / / \mathrm{www} . \mathrm{bbj} . \mathrm{hu} / \mathrm{economy/hungary}$-china-sign-dozen-agreements-during-state-visit_58566; Peter Wise and Leslie Hook, "China's State Grid to take 25\% stake in REN," Financial Times, February 2, 2012, accessed on February 25, 2012, http://www.ft.com/cms/s/0/41 a0c572-4dba-11 el -b96c00144feabdc0.html\#axzz2MVsQQcSW; Justin Vaïsse and Hans Kundnan, "European Foreign Policy Scorecard 2012," European Council on Foreign Relations, January 2012: 28, 30, accessed on January 14, 2013, http://ecfr.eu/page/-/ECFR SCORECARD 2012 WEB.pdf

${ }^{92}$ Finkielsztoyn, Micaela, "EU-China relations: lessons for the future," The New Federalist, 30 December, 2012, accessed February 10, 2013, http://www.thenewfederalist.eu/EU-China-relations-lessons-for-thefuture, 05432

${ }^{93}$ Mattlin, "A Normative EU Policy Towards China," 18

${ }^{94}$ Fox and Godement, $A$ Power Audit of EU-China Relations, 33; Men and Balducci. "EU-China Relations in the 21st Century," 27

${ }^{95}$ Fox and Godement, $A$ Power Audit of EU-China Relations, 30

96 "Enter the Dragon: A successful case study of Chinese investment in Poland" Deloitte/Invest in Poland, case study. November 15, 2012, accessed on February 82013 ,

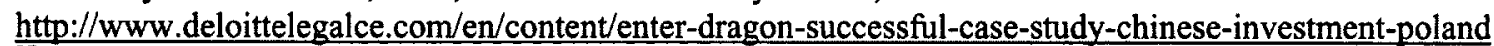
${ }^{97}$ Ibid 
While the member states have always had national China policies, some being particularly well developed (UK, France, Germany), the sovereign debt crisis has dealt a blow to Brussels' attempts at a common China policy and has clearly inspired some to seek semi-institutionalized arrangements outside of the EU's framework.

Another reason the EU needs this legitimation exercise is that the EU is a fragmented actor for whom strategic actorness is a relatively new experience. The EU is, after all, primarily an economic actor, does not have a military, is limited by the US in military issues and, as aforementioned, lacks some cohesion. For these reasons, it is argued that "the EU is not really a strategic entity" and is not always seen as such by the Chinese. ${ }^{98}$ Here one can ask whether the Chinese have a point: is the EU capable of acting strategic about anything at all, given the limits of its military and security? Put another way, China is maybe the only strategic actor in this strategic partnership. ${ }^{99}$

This relates to the ever-present problem of the EU's 'capability-expectations gap,' first proposed by Christopher Hill to describe a gap between the EU's discourse and actual capacity to implement. ${ }^{100}$ As seen previously, the Chinese have ascribed to the EU the quality of being a pole in its vision of the world structure, and of being a counterweight to the US' unilateralism. It is likely that Beijing too easily 'bought-into' the EU's rhetoric of the early 2000's on the CSDP and suggestions of EU battalion groups, thinking it was somehow on its way to becoming a more traditional power. It was around this time that the EU-China 'honeymoon' occurred, and it appears the Chinese

\footnotetext{
${ }^{98}$ Freeman, Geeraerts, Fiott and Cameron, Separate Interviews with Julie Pickering, May 2012, Brussels; Holslag, "The Elusive Axis," 310

99 Defraigne, "Pourquoi la Chine veut une Europe forte?"

${ }^{100}$ Norheim-Martinsen, Per M., "EU Strategic Culture: When the Means Becomes the End," 519
} 
believed in the idea of the EU that was promoted by Brussels. ${ }^{101}$ This naivety can perhaps be understood given China's only recent appearance as a serious international actor.

The EU has lots of strategies, creating new ones for various policy areas. The ESS may even be seen as a grand strategy. However, the EU may not yet have something akin to strategic culture, by which it can make resources at its disposal operational. Allen and Smith have proposed that the EU might be thought of as a strategic actor if it follows the conditions of being able to turn member state resources into international leverage, to establish and meet medium to long-term objectives, having the capacity to adapt to changes in the system, and being able to generate a strategic narrative. ${ }^{102}$ It would seem that the EU only meets these criteria partially, lacking in particular the capacity to extract and utilize member state strategic resources for the EU level. Certainly the strategy for strategic partnerships is not defined, as Mr. Van Rompuy acknowledged himself, saying in 2010 that "we have strategic partners, now we need a strategy."103

Even the ESS, with its supposed formative role for European strategic actorness and strategic culture, is limited by competing member states strategic cultures. ${ }^{104}$ If part of the function of this document was to convince actors within and outside of the EU of its strategic capacities, the current states of the CSDP might suggest limited success, or possibly outright failure.

The role of the US in this relationship may also prevent the flourishing of a truly strategic European actor, at least when it comes to a relationship with a power like China. China's relationship with the EU has been frequently been studied in the context of the

\footnotetext{
${ }^{101}$ Renard, Thomas, Interview with Julie Pickering, May 2012 Brussels

${ }^{102}$ Allen and Smith, "The EU, Strategic Diplomacy and the BRIC Countries," 3

${ }^{103}$ Gratius, "The EU and the "special ten"" 2

${ }^{104}$ Norheim-Martinsen, "EU Strategic Culture," 529
} 
EU-US-China 'strategic triangle,' which describes the US presence in all things EUChina. The US has been called the "elephant in the room in EU-China relations," and some have suggested the Chinese are surprised and disappointed with the EU remaining so close to Washington. ${ }^{105}$ Washington itself may have overlooked developments in the relationship, which has the potential to complicate the traditional transatlantic alliance, and potentially isolate the US from China. ${ }^{106}$ The case of the arms embargo attests to the primacy of the Americans in EU-China relations. The embargo was put in place by the Europeans and Americans in the aftermath of the 1989 Tiananmen massacre, but by the early 2000s, European leaders in a number of countries were reconsidering the embargo, mainly for economic reasons. Lured by the promise of lucrative contracts with European arms firms, particularly in France and Germany, these two countries were vocal in their support for lifting the embargo, though no arguments were put forward about whether there had been a noticeable qualitative shift in the human rights situation in China. ${ }^{107}$ The eventual decision to maintain the embargo, rather than a measure in defense of human rights principles, is said to have resulted from US pressure on Brussels. Positing it as crucial for the maintenance of the transatlantic security regime, Washington succeeded in convincing the Europeans to formally close discussions on the embargo around 2005. ${ }^{108}$ To the Chinese, this is a clear sign that the EU's CFSP is not yet a reality. ${ }^{109}$

\footnotetext{
${ }^{105}$ Cameron, Fraser, Interview with Julie Pickering, May 2012, Brussels; Men and Balducci, "EU-China Relations in the 21 st Century," 26

${ }^{106}$ Holslag, "The Elusive Axis," 294; Bates Gill and Melissa Murphy, China-Europe Relations: Implications and Policy Responses for the United States (Washington, D.C.: The Center for Strategic and International Studies Press, 2008): 30-35

${ }^{107}$ Balducci, "The Limits of Normative Power," 44

${ }^{108}$ Mattlin, "A Normative EU Policy Towards China," 13; Anton La Guardia, "US fury over EU weapons for China," The Telegraph, 15 January, 2005, accessed on January 10, 2013, http://www.telegraph.co.uk/news/1481253/US-fury-over-EU-weapons-for-China.html

${ }^{109}$ Dai, "Promoting Mutual Understanding- China perspective," 257
} 
In other ways, the $\mathrm{EU}$ is certainly a strategic actor; its capacity to initiate a vision for itself indicates a strategy for its role in global affairs. Being able to formulate and discursively justify a long-term vision for itself, the EU may be thought of as an embryonic strategic actor, particularly given that the creation of a strategic partnership framework for its relations with China indicates that this narrative is capable of being actualized and instrumentalized. The overall idea remains that this narrative is viewed as necessary for the EU to frame itself as a strategic actor, something which is rendered difficult at times because the EU is not a traditional state actor.

2. An instrument/ tool for organizing EU-China relations: The use of the strategic partnership narrative as a tool or instrument for organizing EU-China relations is also instrumentalized, seen primarily in the high-degree of institutionalization of relations in specific fora and meetings. This would relate to the narrative of strategic partnership and its insistence on the EU working with external partners on a set of strategic issues, both bilateral and global in nature. In fact, this is one of the major successes of the strategic partnership- attested to by the large number of working groups and dialogues. Some authors have noted that the increasing number of sectoral dialogues between these two actors define the two's relationship. ${ }^{110}$ However, again, concerns are raised about the substance of these meetings, and whether they actually achieve results.

3. Mutual understanding: The narrative suggests that the two actors work closely together on a wide-range of strategic issues, and have mutual understanding of world affairs and common goals to achieve. Given that there are numerous working groups and dialogues

\footnotetext{
${ }^{110}$ Robert Ash, « Europe's commercial relations with China, » in China-Europe Relations: Perceptions, policies and prospects, Shambaugh, David, Eberhard Sandschneider and Zhou Hong, Eds. (London: Routledge, 2008), 193
} 
on these issues, there is, at some level, instrumentalization of this taking place. This part of the narrative, in practice, would then be recognized through the creation of joint projects and initiatives on areas of concern to both sides. Furthermore, the amount of attention or resources placed on these areas in summits and other institutionalized fora would indicate a high degree of mutual understanding and convergence.

Kerr and Liu see this mutual understanding instrumentalized in the form of problem-solving initiatives on certain pragmatic areas. ${ }^{11}$ This part of the narrative has generated actions in areas that are to be considered strategic in the security and military sense. The Chinese participation in the EU's Galileo satellite program, for example, worrisome to the Americans, or their cooperation in anti-piracy efforts off the coast of Somalia, are examples of cooperation on sensitive military and security issues. ${ }^{112}$ This cooperation exists at the member-state level also; joint naval exercises between the Chinese and the French were conducted near Qingdao in China in 2004. ${ }^{113}$

China's 2002 introduction of its 'new security concept', based on "mutual trust, mutual benefit, equality, and cooperation," is revealing of China's new approach to military/security relations. ${ }^{114}$ This entails a great deal of cooperation with other countries, while still maintaining sovereign security as the primary block and countries as the basic actors. In fact, there are some commonalities between the European and Chinese rhetoric on security, both of which focus more on 'common security' rather than 'absolute security.' Cabestan looks at how the idea of 'common security' is based in regionalism

${ }^{111}$ Kerr and Liu, "Introduction," 3

112 Scott, "China-EU convergence 1957-2003," 229

113 "France joins China navy drills," CNN International, March 19, 2004, accessed February 1, 2013 , http://edition.cnn.com/2004/WORLD/asiapcf/03/16/china.navy/

${ }^{114}$ Zhang, Tuosheng, "On China's concept of the international security order," 30 
and deals with conflict through political, economic and cultural means. He argues that China is much more influenced by this model of 'soft power' than the USA-style 'hard power,' and sees this most clearly in the Chinese concepts of duoying or shuangying (win-win). ${ }^{115}$ It has been suggested that the Chinese see many commonalities between the CFSP and its own Five Principles of Peaceful Coexistence, by which they seek a cooperative aspect to dispute-resolution. ${ }^{116} \mathrm{Scott}$ argues that there are commonalities between China's official 'Peaceful Development' model and the EU. ${ }^{117}$ Odgaard and Biscop reiterate this theme, claiming that their approaches to security, stability and conflict prevention bear many similarities. ${ }^{118}$ Some authors have argued that there is in fact a willingness in Beijing to learn from the European model of governance and politics, particularly its institutionalization, civilian power, and multilateral institutions. ${ }^{119}$ There is, however, the very real problem of some disconnect between the EU and China's views on the international order. That the EU and China have contrasting belief and value systems should be no surprise to the casual observer. Furthermore, despite the talk of the EU's support for multilateralism and globalization, there are real limits of these trends globally, and even perhaps a return to power politics, especially given the current economic situation in the Eurozone. This is best exemplified in the reactions of the European public to economic success of Asia, which has led to calls for increased

\footnotetext{
115 Jean-Pierre Cabestan, "Learning from the EU?: China's changing outlook towards multilateralism," in China and the New International Order, Wang, Gungwu and Zheng Yongnian, Eds. (New York: Routledge, 2008): 206-209.

${ }^{116}$ Shambaugh, David, "China eyes Europe in the world: Real convergence or cognitive dissonance?" 131

${ }^{117}$ David Scott, "The EU-China 'Strategic Dialogue': Pathways in the International System," in The International Politics of EU-China Relations, David Kerr and Liu Fei, Eds. (Oxford: Oxford University Press, 2007), 22

${ }^{118}$ Odgaard and Biscop, "The EU and China: Partners in Effective Multilateralism?" 71

${ }^{119} \mathrm{Zhu}$ Liqun, "Chinese perceptions of the EU and the China-Europe relationship," in China-Europe Relations: Perceptions, policies and prospects, Eds. Shambaugh, David, Eberhard Sandschneider and Zhou Hong (London: Routledge, 2008.): 151, 155; Stanzel, "The EU and China in the global system," 255
} 
protectionist measures. Jokela sees this trend most clearly in the European actors' refusal to reform key global institutions, such as the UN, IMF and G8, to better represent the world's population today. ${ }^{120}$

The EU also views state sovereignty as something that is in decline; as Javier Solana has noted, "the principle of sovereignty...produced the basis for rivalry, not community of states; exclusion, not integration." ${ }^{121}$ Yet China's politico-normative system is very much rooted in the Westphalian tradition: its focus is on sovereignty, noninterference and traditional diplomatic engagement. These political norms have been seen in everything ranging from traditional bilateral diplomacy to Beijing's behaviour in its participation in international organization negotiations. ${ }^{122}$

China is guided by a self-perception of its global position as a duality both as a developing country and a (potential) world power, which shapes the country's external relations. ${ }^{123}$ As a result of its unique position, China is developing a new type of international relations based on principles of non-confrontation, non-alignment, and cooperation. ${ }^{124}$ Beijing has its own ideas about how the world system should operate, and the extent to which China will be willing to modify this system to meet their own policy objectives is still unclear. Rather than being a revisionist power, the Chinese have proven to be willing to integrate into the existing structures, though increasingly doing so on

\footnotetext{
120 Juha Jokela, « The European Union as an International Actor : Europeanization and Institutional Changes in the Light of the EU's Asia Policies,") in The Role of the European Union in Asia. China and India as Strategic Partners. Bart Gaens, Juha Jokela and Eija Limnell, Eds. (Surrey: Ashgate Publishing, 2009), 45

121 Javier Solana, "Securing Peace in Europe," (Speech presented at Symposium on the Political Relevance of the 1648 Peace of Westphalia, 12 November, 1998) accessed February 2013.

http://www.nato.int/docu/speech/1998/s981112a.htm

122 This paragraph was taken from an essay written for another class

${ }^{123}$ Zhang Tiejun, "Sino-European Relations : From the Height to the Width," 123

${ }^{124}$ Zhang, Tuosheng, "On China's concept of the international security order," 39
} 
their own terms. ${ }^{125}$ As a result, Pan Zhanqi has argued that there exists a "conceptual gap" between the Chinese and the EU on the meaning of sovereignty, and that different interpretations of this concept, he argues, leads to fundamental misunderstandings and challenges in their relationship. ${ }^{126}$ According to Pan, the Chinese authorities and academics hold a more Hobbesian view of sovereignty, in which the latter is either present or no state can exist; there can be no semi- or partial-sovereignty. ${ }^{127}$ China's government is known best for its pragmatism, based first and foremost on fostering domestic economic growth. This 'development mantra' has been the CCP's battle cry for decades, providing justification for the party's deep involvement in enterprise and investment, as well as curtailing citizen freedoms. Motivated both by geopolitical and economic considerations, the CCP has recently developed partnerships with third countries, investing heavily in the Asia-Pacific and increasingly in far-removed continents. This reaching-out is particularly impressive in the context of EU-China relations, where Beijing has actively sought to work closely with Brussels in a multitude of policy areas. The success story of China's economic growth is well known, and some authors project that it will become the world's first economy in the next decade. ${ }^{128}$ As a foreign policy actor, China is increasingly seeking to aid its market rebalancing efforts from export-led to consumer-led growth, and its foreign overtures are intrinsically linked to these domestic considerations. ${ }^{129}$ According to this argument, Chinese foreign policy

\footnotetext{
${ }^{125}$ Geeraerts, Gustaaf, Interview with Julie Pickering, May 2012, Brussels

${ }^{126}$ Pan Zhongqi, "Managing the conceptual gap on sovereignty in China-EU relations," Asia Europe Journal, 8 (2010): 227

${ }^{127}$ Pan, "Managing the conceptual gap on sovereignty in China-EU relations," 231; this paragraph was written in an essay for another class

${ }^{128}$ Geeraerts, Gustaaf, Interview with Julie Pickering, May 2012, Brussels

${ }^{129}$ Ibid
} 
is grounded in Chinese economic development, focused on resource accumulation and extraction, and the maintenance of markets for Chinese goods abroad.

In addition, while the Chinese do focus a great deal of energy on the ideas of a peaceful rise and adherence to multilateralism, this is still experimental. ${ }^{130}$ In fact, in its relations with the EU, the Chinese have displayed a willingness to play by the official rules of the international game, perhaps in order to achieve its aforementioned pragmatic economic interests. China has earned to talk-the-talk, but it is not yet clear that it seeks those same ends for their own sake. Many authors also provide critiques of China's 'lipservice' to multilateralism, which they see as selective and limited. China supports these efforts away from its own territory, where other powers cannot destabilize its sovereignty. ${ }^{131}$ Or perhaps, as Stumbaum argues, China confuses multilateralism and multipolarity, and therefore comprehends multilateralism differently than the EU. ${ }^{132}$ In fact, some authors hint at the fact that the pro-EU rhetoric in China is limited partly due to the fact that its support for multilateralism is simply an attempt to achieve multipolarity, and a balance to USA power, which is not an EU goal, per se. ${ }^{133}$

4. Equality of partners: The claim is made discursively of equality of partners, but to what extent is this actualized? This actualization would require the two actors to generate actions and behaviours that indicate symmetry and partnership. Certainly there is no overt asymmetry at the discourse level in EU-China relations, and this seems to be reflected officially in the EU's actions, which are arranged in such a manner as to suggest equality.

\footnotetext{
${ }^{130}$ Odgaard and Biscop, "The EU and China: Partners in Effective Multilateralism?" 77

${ }^{131}$ Cabestan, "Learning from the EU?" 213

${ }^{132}$ May-Britt U. Stumbaum, "Europe's views on China's role in international security,"

in China, Europe and International Security: Interests, Roles, and Prospects, Van der Putten, FransPaul and Chu, Shulong, Eds. (London: Routledge 2010): 14

${ }^{133}$ Cabestan, "Learning from the EU?," 211
} 
For example, in the aftermath of EU-China Summits, joint statements or press releases are issued by the two, highlighting the summarized positions of both sides and indicating the parity of their views. While the EU institutions often publish separate press releases, these in no way modify the positions provided by the joint statements. Similarly, dialogues and summits almost always alternate between a European and Chinese venue, also indicating an explicit effort at recognizing both actors equally. In many respects, the favoured dialogue formats support the claim of equality of partners by allowing for both sides to present their points of view.

However, there is also some difficulty in implementing the narrative's claim of equality of partners. Recent events, such as the Eurozone crisis, may have shifted the power balance in the relations, leading to questions about the actual equality of these two actors in negotiation settings. Today, many commentators in both the EU and China think the Chinese dictate the terms of the relationship. ${ }^{134}$ China has certainly taken many steps to aim to repair the global financial system, and questions may be raised regarding a global shift of attitudes towards China. ${ }^{135}$ There is, for example, an increasing respect for China's role in 'fixing' the Eurozone's chaotic situation, and that the EU finds itself today in a position of recipient in which it cannot 'call the shots' with Beijing.

Viewed from another perspective, the Europeans have not, perhaps until very recently, treated China as an equal partner, despite what it has said officially. Before the crisis, one could argue that "China could be seen as the dominant partner in the relationship... whereas the crisis quite clearly has changed the EU and the EU's position

\footnotetext{
${ }^{134}$ Fox and Godement, eds., A Power Audit of EU-China Relations, 37

${ }^{135}$ Op. cit., 48
} 
in the world." ${ }^{.136}$ While this idea is present at the discourse-level, it may not be effectively activated in that perceptions of the EU have changed.

5. Interest-based: The actualization of interest-based relations should, in theory, be easy to quantify in its implementation. It would require an assessment of whether the strategic partnership narrative has allowed the EU to better engage China in initiatives or projects that generate mutual interests, begging the question of whether these would have been difficult to achieve without a strategic partnership. Much like the idea of mutual understanding and common goals, an interest-based strategic partnership would be measurable to the extent that it has led to the flourishing of new projects and joint ventures that are results-oriented. From a rather narrow angle, then, the strategic partnership may appear to be a success. Mara Caira asserts that the main motivation for the 'strategy' is to materialize action-oriented, not only declaratory, policies. Caira highlights that the convergence between China and the EU is key to the process of sectoral dialogues. ${ }^{137}$ Mikael Mattlin also proposes that the sectoralization of EU-China cooperation is its most successful endeavour, as it allows for certain policy areas to be compartmentalized and therefore isolated from politically sensitive rhetoric. ${ }^{138}$ Certainly trade has flourished, which could be a consequence of joint actions taken on certain trade-related and economic issues which created better conditions for trade and its facilitation.

The actualization of interest-based relations within the strategic partnership is questionable in practice. Again, there is uncertainty as to whether the EU and China have

\footnotetext{
${ }^{136}$ Freeman, Duncan, Interview with Julie Pickering, May 2012, Brussels

${ }^{137}$ Cairi, "The EU-China Relationship: From Cooperation to Strategic Partnership," 263

${ }^{138}$ Mattlin, « Thinking Clearly on Political Strategy,» 104
} 
actually gained much outside of their trade relations, and whether they actually share the same interests. It is possible that what has been achieved is more symbolic than concrete, and there are concerns that little is actually being achieved: this seems justified by the fact that many things were expected of the partnership, but a decade on, there has been no clear major rapprochement. Simply in terms of results, the EU and China do not seem to 'achieve' very much other than cooperation in a few areas or specific projects. The general trend, rather, is one of dialogue and statements on a number of issues, and a fairly high degree of rhetorical or discursive convergence for the two actors.

Others have proposed that the lack of common threats may work to the disadvantage of the partnership, removing it of a certain strategic purpose. ${ }^{139}$ Despite some common interests, that is not the same thing as "unity of purpose," and is not necessarily equal to a strategic partnership. ${ }^{140}$ While there are the standard public pronouncements of friendship and cooperation, both parties often do not seem to move past the initial phase. Projects are initiated and ideas engendered by working groups, but concretization into real actions and the achievement of the intended goals are too rare. This no doubt is a reflection of a very real disconnect in the ways the two actors approach the issues. The more 'normative' these are, the slimmer the chances seem to be that cooperation will generate results. In fact, on a number of issues, EU-China cooperation seems limited to public pronouncements of issues being top joint priorities; little or no action is taken in implementing or operationalizing these statements. Jonathan Holslag undertakes a critical examination of the strategic partnership, looking at statements of joint action by the EU and China on several policy issues, including North Korea,

\footnotetext{
${ }^{139}$ Renard, EU-China: Building Upon a Dialogue Among Strategic Partners, 21

${ }^{140}$ Freeman, Duncan, Interview with Julie Pickering, May 2012, Brussels
} 
Myanmar, Iran, UN reform and WTO. He concludes that there is minimal coordination on these issues, and virtually no actions are taken, and that joint cooperation has remained focused on economic ventures. ${ }^{141}$ Even the summits do not seem to produce many results. ${ }^{142}$

Certainly there exists huge potential for closer cooperation between the EU and China, given shared interests and a surprisingly high degree of convergence, at least rhetorically, on a number of global issues. Even in this, however, it is unclear that the strategic partnership had a role to play, particularly given that the issues of MES and the arms embargo remain unresolved for the Chinese side. ${ }^{143}$

6. Aspirational relations and long-term view: One way that the aspirational quality of the narrative could be instrumentalized is again through the creation of projects between the two actors, particularly those aimed at achieving long-term goals. Arguably the creation of dialogues on major issues like climate change, energy and geopolitical policies, like joint cooperation on Africa, reveal this long-term projection.

Again, however, there is the problem presented by the EU's possible lack of strategic actorness, and the fact that China might have ascribed to the EU an identity which it did not have, and still does not. The realization of the EU's limits, of the existence of a serious capabilities-expectations gap, along with issues of the EU's cohesiveness and a laundry-list of problems in the relations, have all been factors leading tensions in the relations, or the 'marriage.' Jing Men has suggested that expectations in

${ }^{141}$ Holslag, "The Elusive Axis," 298, 309

${ }^{142}$ Renard, "The EU Strategic Partnerships Review," 3

${ }^{143}$ France Diplomatie, Ministère des Affaires Étrangères, « Les partenaires stratégiques de l'Union européenne, " Accessed March 2013, http://www.diplomatie.gouv.fr/fr/politique-etrangere-de-lafrance/europe-828/union-europeenne-et-monde/politique-etrangere-et-de-securite/les-realisations-de-lapesc/article/les-partenaires-strategiques-de-1\#sommaire 3 
2003, when both actors published policy papers, were far too high, and could not realistically be met. ${ }^{144}$ As a result, the Chinese today are disappointed with the EU's CFSP ${ }^{145}$ Others have argued that the political rhetoric on the EU-China relationship has yet to catch up with the political reality. ${ }^{146}$ Shambaugh referred to Chinese policy-makers and academics' 'cognitive dissonance' with regards to the EU, describing a projected view of world affairs, rather than any accurate description of such. ${ }^{147}$ This theme is brought up in much of the secondary literature. In its EU Policy Paper of 2003, Beijing refers to the EU as a pole and major force in the world; it views it in a multipolarity context, which is not necessarily an accurate representation of its current standing, nor is it intuitively how most member states might view it. The Chinese views of the EU are derivative of their beliefs and goals for the world order. Secondary literature suggests that the EU does not actually achieve or realize this Chinese viewpoint, though in many ways it portrays or markets itself that way. Cabestan argues that this is partly to do with the fact that the Chinese have a close relationship to France, and have based their understanding of the EU on French foreign policy, which is much more overtly in favour of multipolarity and opposed to unipolarity than other member states. ${ }^{148}$

It is clear that the EU has engaged in the practice of discursive representations of itself as a strategic actor and strategic partner, particularly since the publication of the ESS. These discursive moments suggest the use of a broader narrative that, among other

\footnotetext{
${ }^{144}$ Men, "Great expectations, complex reality," 6

${ }^{145}$ Men and Balducci, "EU-China Relations in the 21 st Century," 27

${ }^{146}$ Zhang Tiejun, « Sino-European Relations : From the Height to the Width,» 126

${ }^{147}$ Shambaugh, David, "China eyes Europe in the world: Real convergence or cognitive dissonance?" 127

${ }^{148}$ Cabestan, "Learning from the EU?" 210; Jean-Pierre Cabestan, "The Role of France in Sino-European Relations: Central or Marginal," in The International Politics of EU-China Relations, David Kerr and Liu Fei, Eds. (Oxford: Oxford University Press, 2007) 133
} 
functions, allows the EU to internally organize EU-China relations and provide legitimation to some of its nascent foreign policy objectives vis-à-vis the member states and external actors. Analytic features within the narrative provide a mechanism by which to gauge when the narrative is present, whether discursively or through its instrumentalization. While the narrative does seem to generate actions, major ambiguities exist within the narrative, the EU itself, and official EU-China relations that suggest it may not always be possible for the EU to act accordingly. It is not always clear, for example, that the EU and China's relations are themselves a real partnership or that they are strategic, given that this would require the effective actualization of a number of elements that have been identified above. It is possibly because of this confusion that the Chinese (naively) thought the arms embargo would be removed once the partnership was put in place: what kind of partner would impose, or maintain, a sanction against the other? ${ }^{149}$ Does this not show the ambiguity in the use of the term 'partners'? Taken this way, it is not always clear that the two's relations, despite its intensification over the past decade, is worthy of such a title.

${ }^{149}$ Dai, "Promoting Mutual Understanding- China perspective," 256 


\section{Chapter: The Narrative of Normative Actorness}

\subsection{The narrative of normative actorness}

The second narrative is that of normative actorness to China. In the following section, the discursive basis of the narrative will be presented, after which conceptualization of its instrumentalization will be provided, along with ambiguities and difficulties the EU encounters in doing so. Finally, an attempt will be made to broaden the conception of norms to include economic and market values, and to ask whether it is possible or even enviable to separate between norms and interests, to see whether this might support the normative narrative or not.

Norms do influence the EU's actorness in foreign policy, at the very least to the extent that the EU frequently engages in a constructivist exercise by which it gives itself this identity, or discursive representation. ${ }^{1}$ This identity is presented in its relations with the member states, but more importantly for this study, in its relations with external partners and actors. Part of the function of this narrative and discursive practice is identity-construction, and much like the narrative of the strategic partnership, has a legitimizing function. ${ }^{2}$ Rather than constructing itself as an important actor in the strategic sense of systemic shifts, this narrative is more about referencing the EU's aforementioned exceptionalism, based on 'othering' its violent past and also external actors, because its own trajectory truly holds the 'secret' to enviable political post-

\footnotetext{
'Thomas Diez, "Constructing the Self and Changing Others: Reconsidering "Normative Power Europe," Millennium: Journal of International Studies, 33:3 (2005): 626

${ }^{2}$ Jan Zielonka, "Europe's new civilizing missions: the EU's normative power discourse," Journal of Political Ideologies, 18:1 (2013): 36
} 
modernism. ${ }^{3}$ Because the EU has "from the start...rejected realistic determinism," acting constructively or normatively is really the only option. ${ }^{4}$

These ideals and norms form part of the EU's ontology, as they are referenced in the treaties, and international agreements such as the Charter of Fundamental Rights of the EU. The EU also references other international treaties, such as the International Declaration of Human Rights, the International Covenant on Economic, Social and Cultural Rights and the International Covenant on Civil and Political Rights. A normative narrative is very important to the EU's identity, and is found from the beginning in Robert Schuman's declarations and the original documents of the European Coal and Steel Treaty of $1951 .^{5}$ Today, references to this type of identity are found throughout the acquis communautaire and throughout contemporary publications like the ESS and the articles of the Lisbon Treaty, along with official statements and pronouncements from the major institutions.

The EU has had a successful internal experience with norms; the integration project emerged out of a period of tragedy in European history, positing itself as a means of overcoming intra-state war. This process involved recognizing certain norms, such as rule of law, respect for human rights and protection of minorities, as instrumental in developing a strong Union. It has also included the acceptance of norms about how liberal markets should operate, in order to generate the greatest possible economic benefits with the lowest negative impact on individuals. The integration project can itself

\footnotetext{
${ }^{3}$ Diez, "Constructing the Self and Changing Others," 634

"Zaki Laïdi, "Europe and World Governance Norms Over Force, " Sciences Po in China, Working Paper Series 2, (November 2007) : 6

${ }^{5}$ Ian Manners, "Normative Power Europe: A Contradiction in Terms?" Journal of Common Market Studies, 40.2 (2002): 242
} 
be considered normative in that it has successfully propagated norms which "displace the state as the centre of concern," focusing instead on the inherent rights of groups and individuals in a pan-European forum. ${ }^{6}$ There is debate about how the internal normative process has occurred, and there is no consensus by theorists of Europeanization. What is generally accepted is that the EU has been successful in establishing specific norms within its borders, and today these are considered 'benchmarks' for new members. Given the important role of norms in the EU, this forms a major part of its identity and selfunderstanding. As it increasingly engages other countries through its nascent foreign policy capacities, it seems poised to promote and project these into the global system. It sees itself as a global leader, not in military terms, but in global governance: a global governance model based on norms rather than force. ${ }^{7}$ In its official discourse on foreign policy, it also utilizes this logic of constructivism to suggest socialization of external actors through engagement with it. Romano Prodi said that "it is not imperialism to want to spread these principles and share our model of society with the peoples of Southern and Eastern Europe who aspire to peace, justice and freedom. Indeed, Europe must go further. We must aim to become a global civil power at the service of sustainable global development. ${ }^{38}$ Robert Cooper, former Director General of the office of the High Representative for CFSP, wrote in a 1996 piece that the EU's task is "to preserve and extend the EU's normative order..." Javier Solana echoed this in 2005, saying the EU

\footnotetext{
${ }^{6}$ Manners, "Normative Power Europe," 236

'Zaki Laïdi, "European preferences and their reception," in EU Foreign Policy in a Globalised World: Normative Power and Social Preferences, Ed. Zaki Laïdi (New York: Routledge, 2008): 4

${ }^{8}$ Laïdi, « Europe and World Governance Norms Over Force, » 7

${ }^{9}$ Diez, "Constructing the Self and Changing Others," 624
} 
has a responsibility to work for the "global common good."10 The ESS reveals this focus on norms and the perception that the EU should aim to improve the world, support "development of a stronger international society, well-functioning international institutions and a rule-based international order" and to "share our goals and values, and are prepared to act in their support" and contribute to "better governance." followed that "we are recognized as an important contributor to a better world."12 Catherine Ashton echoed this in saying that "human rights, democracy and the rule of law are the basic values on which EU foreign policy is built. They are a silver thread running through all that we do." ${ }^{\prime 13}$ Article 11(1) of the Treaty on the European Union states that in defining the CFSP, the objectives should be "to safeguard the common values, fundamental interests, independence and integrity of the Union in conformity with the principles of the United Nations Charter... to develop and consolidate democracy and the rule of law, and respect for human rights and fundamental freedoms." ${ }^{14}$ Most recently, the Lisbon Treaty promoted associating the acquis with foreign relations and promoting

\footnotetext{
${ }^{10}$ Javier Solana, "Shaping an Effective EU Foreign Policy," (Speech presented at at the Konrad Adenauer Foundation, Brussels. January 24, 2005), accessed May 2012. http://www.eu-un.europa.eu/articles/fr/article 4251 fr.htm

"Uwe Wissenbach, "The EU's response to China's Africa safari: Can triangulation match needs?" European Journal of Development Research, 21(2009): 664; A Secure Europe in a Better World: European Security Strategy, 8, 10

${ }^{12}$ Report on the Implementation of the European Security Strategy, 2

${ }^{13}$ Council of the European Union, "EU adopts Strategic Framework on Human Rights and Democracy Luxembourg," Press Release, 25 June 2012. 11737/12 (Presse 285), accessed 16 February 2013, http://www.consilium.europa.eu/uedocs/cms data/docs/pressdata/EN/foraff/131173.pdf; Council of the European Union, Press Release. "Human rights and democracy in the world." 10 May 2010. 9598/10 (Presse 110), accessed January 2013 http://www.consilium.europa.eu/uedocs/cms data/docs/pressdata/EN/foraff/114330.pdf ${ }_{14}$ Algieri, Franco. "It's the system that matters: institutionalization and making of EU policy towards China," 74; Balme,"From Hard to Soft Power, and Return," 1
} 
UN values through its own policies. ${ }^{15}$ The Treaty confirmed that human rights, as stipulated by the Universal Declaration of Human Rights, were central to all of its external policies, including trade and development agreements. ${ }^{16}$ Even in its publications on China, the EU references norms and values and their roles in foreign policy. In the 2006 Commission paper it was argued that "Europe needs to respond effectively to China's renewed strength... we need to leverage the potential of a dynamic relationship with China based on our values."17

The EU's own discourse is closely related to academic works which refer to a disctintiveness about the EU in global affairs. The narrative of the EU's normative actorness, as it is organized in this paper, is an amalgam of ideas and theories, in many ways initiated by the publication of Ian Manners' work in 2002, that reference the EU's actorness as being soft, normative, embedded with values, and/or non-traditional. While there is much debate about what can be called norms or normative, for the purposes of this work the distinction will be made between ethico-political norms, which would relate closely to Manners' definition and are more idealistic and ideational, and economic and market norms, which are still normative but are rooted in interest and material capacity.

It is widely accepted today that the EU is a different kind of actor, Kantian and venusian in its juxtaposition to Hobbesian and martian America. ${ }^{18}$ Francois Duchêne is identified by many as the first to write on the EU's distinct kind of foreign policy power

\footnotetext{
${ }^{15}$ Ian Manners, "The EU's Normative Power in Changing World Politics," in Normative Power Europe in a Changing World: A Discussion. Clingendael European Papers 5. Ed. André Gerrits (December 2009) accessed May 2012, http://www.clingendael.n//publications/2009/20091200 cesp paper gerrits.pdf: 17 16 "Human Rights Dialogue," Delegation of the European Union to China, accessed January 2013 http://eeas.europa.eu/delegations/china/eu china/political relations/humain rights_dialogue/index en.htm ${ }_{17}^{17}$ EU-China: Closer partners, growing responsibilities, 2 18 "'Americans are from Mars, Europeans from Venus."” The Telegraph, March 2, 2003, accessed February 2013. http://www.telegraph.co.uk/news/worldnews/northamerica/usa/1423535/Americans-arefrom-Mars-Europeans-from-Venus.html
} 
with his 1973 text on the EU's 'civilian power. ${ }^{19}$ Since then, Whitman (1998) and Smith (2005) have argued for the EU's actorness as a civilian power, rather than a traditional military power. Börzel and Risse (2009) have proposed that the EU acts as a transformative power in promoting the diffusion of ideas internally and externally. ${ }^{20}$ Orbie (2006) discussed the EU's civilian power and Aggestam (2008) its ethical power. Diez (2005), Adler and Crawford (2004), Sjursen (2006) and Therborn (1997) have all touched on this idea of the EU being a non-conventional actor due to its lack of military force or centrality of ideas and values. ${ }^{21}$

For example, Maull argues that a power is civilian when "its foreign policy role and behavior is bound to particular aims, values, principles, as well as forms of influence and instruments of power in the name of a civilization of international relations," and that the EU fits this description. ${ }^{22}$ Jokela has proposed a conception of the EU as a 'global model-power,' by which it draws on its own external experience (and successes) to act internationally, rather than acting as a superpower, according to which it seeks to make long-term systemic changes to third countries through stronger activism on the world stage. $^{23}$

Many observers accept that the EU's ability to act globally is based on soft tools, such as "trade policy instruments, cooperation agreements, social and environmental policies, humanitarian assistance... civilian and military crisis management capabilities,

\footnotetext{
${ }^{19}$ Manners, "Normative Power Europe," 236

${ }^{20}$ Börzel, Tanja A. and Thomas Risse. "The Transformative Power of Europe: The European Union and the Diffusion of Ideas." KFG Working Paper Series, 1 (May 2009): 3. Accessed March 2013. http://userpage.fu-berlin.de/kfgeu/kfgwp/wpseries/WorkingPaperKFG 1.pdf

${ }^{21}$ Robert Falker, "The political economy of 'normative power' Europe: EU environmental leadership in international biotechnology regulation," Journal of European Public Policy, 14: 4 (2007): 507

${ }^{22}$ Diez, "Constructing the Self and Changing Others," 617

${ }^{23}$ Jokela, Juha, « The European Union as an International Actor : Europeanization and Institutional Changes in the Light of the EU's Asia Policies,» 38-39
} 
diplomatic instruments and cooperation in the area of Justice and Home Affairs," rather than military or hard power. ${ }^{24} \mathrm{The} \mathrm{EU}$ is a credible and important actor in international affairs, particularly in trade, and is not recognized as a military power. ${ }^{25}$ This, it is argued, is a distinct point of difference between the Europeans and American's conceptions and capabilities of foreign policy. ${ }^{26}$ Laildi refers to this as the EU's 'preference for norms': perhaps instinctually, it is argued, the EU supports the diffusion of norms abroad because of its particular 'actorness' in global politics. The EU would show this preference in part because it has no real other options, in that it cannot act like a traditional state because of limits on its military power and its atypical multilevel construct. Given that the EU is not a traditional state actor, has little military capacity, and uses soft tools and instruments on a number of policy issues, there is reason to believe that the EU is a distinct type of entity. It also provides a strong foundation on which to build a normative narrative.

Perceiving themselves to be normative, the EU has a mission, which involves, among other things, the provision of GPGs in certain areas, such as environmental diplomacy or sustainable development. ${ }^{27}$ The provision of GPGs are central to the EU's normative leadership role, and are related to the context of the post-Cold War, in which the EU saw an opportunity to promote a world of norms and regulations on many levels, in order to create complex interdependence. ${ }^{28}$ Furthermore, the European integration

\footnotetext{
${ }^{24}$ Rosemary Foot, "Strategy, politics, and world order perspective: comparing the EU and US approaches to China's resurgence," in US-China-EU Relations: Managing the new world order, Eds. Robert Ross, Øystein Tunsjø and Zhang Tuosheng (London: Routledge, 2010): 213

${ }^{25}$ Zaki Laïdi, "Les conséquences inattendues de la puissance européenne," Garnet Policy Brief, Centre D'études Européennes (December 2007): 2

${ }^{26}$ Diez, "Constructing the Self and Changing Others," 614

${ }^{27}$ Falker, "The political economy of 'normative power' Europe," 510

${ }^{28}$ Laïdi, "Les conséquences inattendues de la puissance européenne," 5
} 
project is in many respects a normative one by its very nature, and it has therefore become very apt at using this kind of power- it is only natural that it projects this in its relations with external actors in the form of a narrative. ${ }^{29}$ Diez proposes that through this discourse the EU engages in the practice of 'othering,' by which the EU represents the other as 'different' or not yet achieving universal principles, and so it needs to show others how things are done. ${ }^{30}$

It was within a broader context of academic works on the EU's distinct actorness that the literature on Normative Power Europe (NPE) emerged with the publication of Manners' seminal work in 2002, which focuses on the EU's actorness in global politics being based on norms and values. His work has aroused the biggest response by both critics and supporters. ${ }^{31}$ Manners' argument is that the EU's power is, at its heart, ideational, rather than material or physical, because the EU is a sui generis actor that challenges traditional forms of state actorness, and therefore also the relations between states. ${ }^{32}$ This non-materialist and idealist nature of Mannersian normative power is grounded in the claim of the universality of certain norms, which derive their legitimacy today from international conventions and treaties, acting (according to some) as a distinguishing factor to the US' normative power, which it establishes and exercises more

\footnotetext{
${ }^{29}$ Laïdi, "Les conséquences inattendues de la puissance européenne," 4

${ }^{30}$ Diez, "Constructing the Self and Changing Others," 628-629

${ }^{31}$ Richard G. Whitman, "Normative Power Europe: A New Agenda for Study of the EU and International Relations," in Normative Power Europe: Empirical and Theoretical Perspectives, Ed. Richard G. Whitman (Hampshire, UK: Palgrave Macmillan, 2011): 1; André Gerrits, "Normative Power Europe: Introductory Observations on a Controversial Nortion," in Normative Power Europe in a Changing World: A Discussion. Clingendael European Papers 5, Ed. André Gerrits (December 2009): 2, accessed May 2012. http://www.clingendael.nl/publications/2009/20091200 cesp paper gerrits.pdf

${ }^{32}$ Manners, "The EU's Normative Power in Changing World Politics," 11
} 
unilaterally. ${ }^{33} \mathrm{He}$ specifically outlines five core norms at the heart of the EU's acquis: peace, democracy, human rights, rule of law and liberty. Four minor norms are also proposed: social solidarity, anti-discrimination, sustainable development and good governance. ${ }^{34}$ These documents, it is claimed, reflect norms that are global in nature and have been agreed upon by a diverse set of countries. ${ }^{35}$

To Manners and many other theorists of normative power, norms are rooted in the EU's ontological experience. Although many critics of the EU view its adherence to norms and values to be half-hearted or inherently reflective of strategic motives, one cannot deny the centrality of values in the treaty system and in official documents. The EU is a community of values, at least rhetorically, and this was most recently enshrined in the Lisbon Treaty. ${ }^{36}$ Manners' NPE referred to the ability of the EU to define what the 'normal' is in international relations because of what it is. ${ }^{37}$ The EU is ontologically normative, whether by design or by default. ${ }^{38}$

A number of authors write of normative power owing its existence to a particular time and space in world history. For Kagan, the EU's normative actorness owes exclusively to the lack of alternatives- it simply cannot be a world power in the traditional sense of the word. ${ }^{39}$ Gerrits argues that it survives due to 'Zeitgeist', and posits

\footnotetext{
${ }^{33}$ Manners, "The EU's Normative Power in Changing World Politics," 12; Diez, "Constructing the Self and Changing Others," 622

${ }^{34}$ Manners, "Normative Power Europe," 242

${ }^{35}$ Lisbeth Aggestam,"The World in Our Mind: Normative Power in a Multi-Polar World," in Normative Power Europe in a Changing World: A Discussion. Clingendael European Papers 5, Ed. André, accessed May 2012, http://www.clingendael.nl/publications/2009/20091200_cesp_paper_gerrits.pdf, (December 2009): 28

${ }^{36}$ Asle Toje, "Normative Power in Europe after the Post-Cold War," in Normative Power Europe in a Changing World: A Discussion. Clingendael European Papers 5, Ed. André Gerrits (December 2009), 40, accessed May 2012, http://www.clingendael.nl/publications/2009/20091200 cesp paper gerrits.pdf

${ }^{37}$ Manners, "Normative Power Europe," 231

${ }^{38}$ Gerrits, "Normative Power Europe," 4

${ }^{39}$ Diez, "Constructing the Self and Changing Others," 620
} 
that structural factors played the vital role in the emergence of this type of actorness, rather than any steps taken by the EU itself. ${ }^{40}$ Hyde-Price views the application of Manner's theory as limited by the clear bipolar origins of the EU's normative power, and emphasizes the spatial-temporal factors in the rise of the EU itself and its particular actorness on the global stage. A soft power can dominate in Europe only because of an explicit guarantee of hard power from Washington. ${ }^{41}$ The situation has been described as one in which "the US makes the dinner, and the EU does the dishes."

Separate from the question of whether the EU instrumentalizes successfully the normative narrative, creating leverage or power, one can see that there is an explicit attempt to present itself as such, and widespread support in academia that the EU is somehow normative, whether because of structural limitations or preference. On some level, then, there is no denying either the existence of normative elements in the EU's identity, which fuel academic writings on the particular nature of the EU construct, or the fact that the EU discursively presents itself as normative, thus creating a narrative around this identity-projection.

\subsection{Instrumentalization of the narrative}

Does the EU instrumentalize this normative narrative? Manners provides the example of the death penalty as a way in which one could test the EU's instrumentalization of this normative power. As mentioned, the EU might actualize this power at the global level because it sees an opportunity for it to project, and hopefully

\footnotetext{
${ }^{40}$ Gerrits, "Normative Power Europe," 4

${ }^{41}$ Adrian Hyde-Price, "Normative' power Europe: a realist critique," Journal of European Public Policy, $13: 2(2006)$ :

${ }^{42}$ Diez, "Constructing the Self and Changing Others," 623
} 
have codified in some manner, a code of accepted norms that will shape international affairs through interactions with itself and multilateral institutions. Implicit here is the idea that there is limited space for norms in multilateral fora; the UN, WTO and International Labour Organization (ILO) will only institutionalize one interpretation of a norm, despite the diverging views of all member countries. The EU likely views international negotiations as opportunities to 'upload' norms or 'enmesh' other countries, particularly emerging markets in arrangements, often legal ones, that it supports. This has been analyzed under the framework of GPGs by Odgaard and Biscop, whose politiconormative approach is heavily influenced by the belief that the EU's goal is to 'enmesh' China in a system of effective multilateralism through the promotion of GPGs. ${ }^{43}$ In the globalized world, each state has a stake in having the norms that are internationally recognized be as close as possible to its own. ${ }^{44}$

In practice, the EU instrumentalizes this type of actorness through the use of a variety of traditional diplomacy tools, including declarations, high-level discussions, special envoys and diplomatic sanctions, including through the framework of the CFSP. It can also use accession negotiations, conditionality through trade arrangements, and undertakings through its membership in multilateral organizations. Manners identifies specific mechanisms through which the EU has a special ability to shape international norms: contagion, cultural filter, informational diffusion, procedural diffusion, overt diffusion, and transference, which are more or less direct forms. ${ }^{45}$ Maull has argued that the language in the EU's foreign policy documents hints at the EU's 'transformationist'

\footnotetext{
${ }^{43}$ Odgaard and Biscop, "The EU and China: Partners in Effective Multilateralism?" 55

${ }^{44}$ Laïdi, "Les conséquences inattendues de la puissance européenne," 7

${ }^{45}$ Manners, "Normative Power Europe," 245
} 
powers, undertaken through its soft power, which include powers of persuasion, enticement, negotiations, and various tools for applying pressure ${ }^{46}$ Checkel has identified mechanisms for norm-exporting, such as shaming, pressuring, learning, socialization and internationalization, which include passive and active modes. ${ }^{47}$

With regards to China, the EU views norms as forming an integral part of its policies, and one major way it generates actions in its relations with China is arguably through 'constructive engagement,' by which the EU would be able, over time, to socialize other actors and to create political or normative spillover. ${ }^{48}$ This corresponds somewhat to Manners' idea of norm diffusion through informational diffusion, by which the EU purposefully embeds official policies with norms. The EU frequently issues statements and declarations on China, and the European Parliament issues resolutions critical of Beijing, which also indicate informational diffusion. The EEAS position is that the EU's norms have never been sidelined in relations with China, but rather that they have been mainstreamed in all of its policies, which would suggest something like transference, in which norms are diffused through the EU's market exchanges, and therefore form part broadly of all elements of its foreign policies. Possibly the EU is also engaged in cultural filter and contagion mechanisms through its interaction with Chinese citizens via people-to-people exchanges, the parliamentary exchange and more generally when Chinese and European officials come together in a working group or dialogue setting. There is also the possibility of the EU engaging in overt diffusion through the

\footnotetext{
${ }^{46}$ Hanns W. Maull, «The European Union as civilian power : aspirations, potential, achievements, » in USChina-EU Relations: Managing the new world order, Eds. Robert Ross, Øystein Tunsjø and Zhang Tuosheng, (London: Routledge, 2010): 50

${ }^{47}$ Checkel, "International Norms," 474-475

${ }^{48}$ Mattlin, "A Normative EU Policy Towards China," 11
} 
undertakings of its delegation and offices in China, where it works with Chinese ministries on a variety of initiatives, including rule of law and environmental projects.

However, there are numerous problems and ambiguities associated with this narrative and its instrumentalization, which relate both the EU's inability and unwillingness to exercise this normative narrative. The EU, for example, often ignores its norms in favour of self-interest and motives that may, in fact, jeopardize normative pursuits. A key problem here is the lack of EU cohesion, with member states often continuing to be motivated by pragmatic considerations, which would prevent them in some instances from acting in accordance with the normative principles in question. ${ }^{49}$ Member states jeopardize the EU's normative commitments by modifying or dropping more sensitive issues in order to gain economically from its relationship with China. The use of common positions and joint actions published by various EU institutions are today, for example, almost never targeted to the 'great powers': the US, Russia, China or India. ${ }^{50}$ The Chinese have demonstrated that there are consequences for member states criticizing Beijing: as mentioned, the Chinese leadership cancelled visits to Germany in 2007 in response to Angela Merkel's meeting with the Dalai Lama in Berlin. ${ }^{51}$

In fact, some argue that normative policies are pursued by the EU only in the absence of a lack of defined interests. ${ }^{52}$ Zielonka looks at the EU's norm-projection

\footnotetext{
${ }^{49}$ Mattlin, "A Normative EU Policy Towards China," 6

${ }^{50}$ Op. cit., 7

${ }^{51}$ Op. cit., 17; "La rencontre entre le dalaï-lama et Merkel provoque l'ire de la Chine," Le Figaro, September 26, 2007, accessed April 1, 2013, http:/www.lefigaro.fr/international/2007/09/26/0100320070926AR TFIG91526-la rencontre entre le dalai lama et merkel provoque 1 ire de la chine.php 52 Tatiana Romanova, "Normative Power Europe: A Russian View," in Normative Power Europe in a Changing World: A Discussion. Clingendael European Papers 5, Ed. André Gerrits (December 2009): 60, accessed May 2012, http://www.clingendael.nl/publications/2009/20091200_cesp_paper_gerrits.pdf
} 
exercise as a device to protect European interests abroad. ${ }^{53}$ To Hyde-Price, if, and only if, "core national interests" are not at stake, then EU-led ideational ethico-normative policies can play a role. ${ }^{54}$ There is possibly something to this: while the EU publicly supports a normative narrative, profitable deals from Beijing may convince them to drop more controversial positions, given the increased Chinese foreign investment in the European Union member state (recent measures indicate a tenfold increase in Chinese FDI to EU countries between 2004 and 2011, with current figures estimated at $€ 7$ Billion.) $)^{55}$

Another major problem for the instrumentalization of the normative narrative is that it is only with great difficulty translated into any kind of normative power in the case of China because the EU has so little leverage in promoting compliance with these norms. Bertrand Russell's definition of power is that it is "the production of intended effects," and according to Toje, the EU's normative power often fails this Russellian test. ${ }^{56}$ Toje's claim rests on the idea that the ability to 'back up' non-coercive measures with coercive ones is what makes the former's implementation successful. Without the possibility of coercion (however implicit), non-coercive power is hard to have. ${ }^{57}$ The EU may only be able to focus, or exercise this kind of power, when it has the material capacity to do so. In other words, normative power would be "a reflection of your material capabilities and your economic wellbeing." 58 The EU is increasingly unable to do this given the dire economic situation and an opposite trend in China.

\footnotetext{
${ }^{53}$ Haydon, "Human rights and the development of EU-China relations," 5

${ }^{54}$ Hyde-Price, “"Normative' power Europe," 223

${ }^{55}$ Philip Ebels, "EU sees dramatic surge in investment from China," EUObserver.com, July 6, 2010, accessed on February 15, 2013, http://euobserver.com/china/116537

${ }^{56}$ Toje, "Normative Power in Europe after the Post-Cold War," 47

${ }^{57}$ Op. cit., 48

${ }^{58}$ Geeraerts, Gustaaf, Interview with Julie Pickering, May 2012, Brussels
} 
Certainly it is commonly accepted that the EU is unable to use the same leverage with China as it is with a smaller state, or one for which membership is a possibility. Even Peter Mandelson recognized that the EU could not dictate the solutions to China's problems. ${ }^{59}$ Due in part to its government, level of development and distinct cultural system, China has been called the ultimate 'Gordian knot' for the EU's normative agenda in foreign affairs and the EU's upholding of a normative foreign policy towards China has been questioned extensively ${ }^{60}$ Many argue that when faced with substantive issues, particularly trade-related, the EU tends to set aside this normative foreign policy. Mattlin views the EU's actual China policy as based on a record of its past actions, as being much closer to realist interpretations. He suggests giving NPE a "realist tweak", by which he means it should use a 'defensive' approach to exporting its values, rather than an 'offensive' one. ${ }^{61}$ Jonathan Holslag has referred to the EU's "defective soft power," and argued that EU-China relations "beg" for more realism. ${ }^{62}$ Gustaaf Geeraerts sees a normative EU policy towards China as fairly naïve, even potentially dangerous. ${ }^{63}$

In its relations with countries like the US and Japan, the EU is assured that there are shared value and normative systems, as well as comparable living standards. ${ }^{64}$ Rather, it is in its relationship with developing economies that a clash of norms is most visible. These highly competitive emerging markets challenge the EU's adherence to its specific

\footnotetext{
59 "Official: EU cannot "dictate" solutions to China's problems." People's Daily Online, April 16, 2008, http://english.people.com.cn/90001/90776/90883/6393222.html

${ }^{60}$ Balducci, "The Limits of Normative Power," 37; Chan, "Images, visibility and the prospects," 140; Mattlin, "A Normative EU Policy Towards China," 5; Hyde-Price, "“Normative' power Europe," 223; Hubert Zimmerman, "Realist Power Europe? The EU in the Negotiations about China's and Russia's WTO Accession," Journal of Common Market Studies, 45:4 (November 2007): 820

${ }^{61}$ Mattlin, "A Normative EU Policy Towards China," 6

${ }^{62}$ Holslag, "The Elusive Axis," 294

${ }^{63}$ Geeraerts, Gustaaf, Interview with Julie Pickering, May 2012, Brussels

${ }^{64}$ Laïdi, "European preferences and their reception," 2
} 
set of socio-economic norms, namely by defending the common goal of protecting state sovereignty and fighting those Western ideals seen to be subverting it. ${ }^{65}$ It is questionable why these countries would recognize the EU's "noble, normative self-image." ${ }^{.66}$ In fact, effective multilateralism might suggest the opposite trend, as a decentralization of power naturally leads to decentralization of ideas, which even the EU acknowledges "is accelerating...differences in values. ${ }^{, 67}$

Another ambiguity in the implementation of normative actorness is that, again, this narrative is not coherent because the EU does not itself act coherently in its application of this narrative. There are fissures within the EU that make this actor's adherence to a cohesive set of norms precarious. This is largely rooted in the different economic situations in the member states, as well as differing political traditions regarding certain norms. As it is with the strategic partnership narrative, there is much evidence to suggest that the EU does not act cohesively on the normative front. While the EU-level promotes a normative actorness, the member states are very often acting in accordance with a realpolitik logic. ${ }^{68}$ For this reasons and others, it is not clear to the Chinese that the EU member states are completely prepared to pool their sovereignty in foreign policy. ${ }^{69}$ Even when some member states do have high normative standards, there is the possibility of the EU's 'normative trap,' as proposed by Balducci, according to which the institutional set-up of the EU leads to a 'watering-down' effect of the EU's

\footnotetext{
${ }^{65}$ Zaki Laïdi, "BRICS: Sovereignty power and weakness," International Politics, 49:4 (2012): 614

${ }^{66}$ Zielonka, "Europe's new civilizing missions: the EU's normative power discourse," 35

${ }^{67}$ Report on the Implementation of the European Security Strategy, 1

${ }^{68}$ Holslag, "The Elusive Axis," 294

${ }^{69}$ Mattlin, "A Normative EU Policy Towards China," 18
} 
normative policy in which member states with traditional focuses on political norms might reduce their importance in order to create a common EU position. ${ }^{70}$

The example proposed by Balducci is that of the arms embargo on China, in which divergence of member states' policies towards China became clear. Another example of fissures within the EU is the actor's joint position on China in resolutions brought to the UN Commission for Human Rights. Starting from 1996, France and Germany began to distance themselves from the joint EU positions that were critical of the Chinese government's handling of human rights, in an attempt to develop stronger economic relations with China. ${ }^{71}$ In the individual member state policies towards China, particularly those of the Directoire countries, these contentious areas are no longer the most important elements of their policies towards China. It has also been argued that there has been a member state delegation of responsibilities for these issues to the European level. ${ }^{72}$ The French government, for example, indicated in a policy paper on China that the EU was the best level at which to engage the Chinese on human rights. ${ }^{73}$ Schroeder's government in Germany stressed a "business-oriented approach," according to which human rights would, implicitly, be dealt with at the EU level. ${ }^{74}$ This occurred seemingly despite the indication that the EU-level institutions, in particular the Commission, were unwilling themselves to risk upsetting the Chinese. ${ }^{75}$

\footnotetext{
${ }^{70}$ Balducci, "The Limits of Normative Power," 37-43

${ }^{71}$ Giuseppe Balducci, "Inside Normative Power Europe: Actors and Processes in the European Promotion of Human Rights in China," EU Diplomacy Papers, College of Europe, 8 (2008): 12; This paragraph was taken from another class

${ }^{72}$ Balducci, "The Limits of Normative Power," 52

${ }^{73}$ Op. cit., 50

${ }^{74}$ Ibid

${ }^{75}$ Balducci, "The Limits of Normative Power," 49; This paragraph was taken from another class
} 
There are also instances when the EU goes out of its way to accommodate the Chinese. In 2007 and 2008, for example, when Beijing showed its displeasure with Paris and Berlin over their respective meetings with the Dalai Lama, it has been argued that rather than support each other's positions, Germany and France sought to "capitalise on each other's misfortune" to gain Beijing's favour. ${ }^{76}$ In another case, Javier Solana issued statements criticizing the Taiwanese referendum of 2004, calling it an unnecessary provocation towards China. ${ }^{77}$ Even if such a critique is warranted, it is unclear why no such criticism was aimed at Beijing despite successive attempts to destabilize crossStraits relations. ${ }^{78}$ This position is particularly confusing given France's aforementioned participation in naval drills and war games in 2004 with China, just ahead of the Taiwanese referendum. ${ }^{79}$ The EU showed no indication of gearing similar criticism towards China of its behavior towards Taiwan, for fear of damaging relations. ${ }^{80}$

The question of whether the EU is exercising double standards in its instrumentalization of a normative narrative in another important critique made of the EU's normative narrative. ${ }^{81}$ For example, concerns have been raised regarding certain actions by the EU and its member states, including the questionable treatment of migrants, including Chinese migrants, despite its talk of human rights. ${ }^{82}$ Much like it does with the US, China criticized the participation of member states in Iraq, which it views as aggressive and based on tenuous justification, or in Kosovo, when EU member states

\footnotetext{
${ }^{76}$ Fox and Godement, $A$ Power Audit of EU-China Relations, 7

${ }^{77}$ Mattlin, "A Normative EU Policy Towards China," 11

${ }^{78}$ Ibid

79 "France joins China navy drills"

${ }^{80}$ Mattlin, "A Normative EU Policy Towards China," 11

${ }^{81}$ Diez, "Constructing the Self and Changing Others," 614

${ }^{82}$ Op. cit., 624; Part of this paragraph was taken from an essay written for a different class
} 
operated outside of the UN structure. ${ }^{83}$ The violations of civil and political rights taking place in Europe, and the West more broadly, have not passed unnoticed by the world. In a post-9/11 world of surveillance, arbitrary detentions and the securitization of civilian life, the 'Western model' may have lost part of its appeal. ${ }^{84}$ China is keen to point out these hypocrisies and inconsistencies, particularly in formalized settings like the human rights dialogue, though this is also certainly defensive posturing on its part. ${ }^{85}$

The normative narrative, unlike that of the strategic partnership, suggests a certain asymmetry, in that the EU holds 'lessons' for others. It is not open to being itself a normtaker and self-reflexivity of the EU (and an understanding of the limits of its power) seems to be lacking at the EU level. Looking specifically at China, it can be argued that this is a clear moment when the EU's normative external agenda, with its implied homogeneity, is challenged by its simultaneous promotion of global political heterogeneity. Many scholars have critically analyzed the applicability of normative power in the face of rising global multi-polarity. Wang argues that while the EU encourages diversity and plurality within its borders (this forms an important part of its identity), it seeks something altogether different, much more standardized and homogenous for external actors. ${ }^{86}$ Whilst effective multilateralism is voiced at the official level, normative actorness, as described in a myriad of official documents, suggests that external actors should adapt to and adopt EU norms in one particular form, across-theboard. There is an undeniable tension between the acceptance of a world of 'particuliaristic' norms and the EU's supposedly 'universal' norms. Broadly, this raises

\footnotetext{
${ }^{83}$ Karen E. Smith, "Beyond the civilian power debate," Politique Europeénne. (2005): 80

${ }^{84}$ Mattlin, "A Normative EU Policy Towards China," 16

${ }^{85}$ Fox and Godement, $A$ Power Audit of EU-China Relations, 35

${ }^{86}$ Op. cit., 69
} 
questions about the future applicability of a normative narrative in a multipolar world rooted in traditional notions of sovereign states. ${ }^{87}$ The political and economic rise of China, Russia, India and Brazil, amongst others, has and will continue to challenge conceptions of global norms. The EU's ability, and that of the West more broadly, to be a guiding or dominant actor is undoubtedly confronted by a plethora of competing political and normative narratives. ${ }^{88}$ The EU is sometimes outwardly convinced by the universalistic quality of its norms and values, rather than appreciating the existence of "alternative value communities." ${ }^{89}$ Fiott argues that one result of the emergence of new powers will be the desire by these actors to challenge the status-quo moral leadership by the Western powers. ${ }^{90}$ These states will now be in a position to push their own agendas, possibly normative ones, in the international arena. Practically speaking, China's notion of democratization of international affairs involves reforms of major international organizations, principally the UN and IMF. This is not purely a matter of dividing material power; writing from a Chinese perspective, it has been argued that global multipolarity requires "not only a redistribution, a plurality of powers, but also a decentralization of ideas." ${ }^{.91}$

More cynical interpretations are that the EU projects European norms and portrays them as universal, when it is nothing more than the "internationalization of

\footnotetext{
${ }^{87}$ Aggestam, "The World in Our Mind," 36; Fiott, "The European Union's Normative Power in a Multipolar World," 1; this paragraph is from an essay written for a different class

${ }^{88}$ Part of this paragraph is based on an essay written for another class

${ }^{89}$ Mattlin, "A Normative EU Policy Towards China," 21

${ }^{90}$ Fiott, "The European Union's Normative Power in a Multipolar World," 4

${ }^{91}$ Wang Yiwei, "The Identity Dilemmas of EU Normative Power: Observations from Chinese Traditional Culture," in Normative Power Europe in a Changing World: A Discussion. Clingendael European Papers 5, André Gerrits, Eds. (December 2009): 70, accessed May 2012, http://www.clingendael.nl/publications/2009/20091200_cesp_paper_gerrits.pdf
} 
European policies." ${ }^{92}$ This reading would jeopardize the assertion that the norms are either intrinsically universal in quality or that they are detached from power. Chinese scholar Yiwei Wang put forward three Chinese-perspective critiques of the EU's normative actorness. The first, the "dilemma of representativeness," refers to the fact that the EU is a very unique region in the world, and does not represent most cultures or political models, despite calling its values universal. ${ }^{93}$ The second is the "dilemma of integration," by which he describes the contradiction of the EU advocating diversity within its own borders, but "uniformity (on the basis of its own norms) outside." Finally, Wang proposes the "dilemma of words and deeds," which describes the difficulty for the EU in that when it actively projects norms, it is held to a high-standard: it opens itself up to accusations of hypocrisy and of being coercive in its normative power. ${ }^{94}$

As with other larger powers, China challenges the EU's normative power and has shown itself unwilling to accept indiscriminately European norms and values. Critics have mocked the idea that constructive engagement with China would lead to liberalization and reform domestically. ${ }^{95}$ An important factor hampering the EU's ability to apply a normative narrative towards China is that, not only does China resists these norms, but the narrative may come into direct conflict with domestic Chinese norms. Beijing has used the idea of "democratization of international relations" as an umbrella term for its vision of multipolarity, and has been able to exploit the tension in the EU's competing ideas of world affairs by referencing concepts of cultural relativism and

\footnotetext{
${ }^{92}$ Falker, "The political economy of 'normative power' Europe," 511

${ }^{93}$ Wang, "The Identity Dilemmas of EU Normative Power," 70

${ }^{94} \mathrm{Ibid}$

${ }^{95}$ Fox and Godement, A Power Audit of EU-China Relations, 1
} 
cultural plurality in its foreign affairs. ${ }^{96}$ From a cultural perspective also, China is too proud and increasingly nationalistic: China's colonial past is an important factor in their current relationship to Western/European states, and Chinese commentators are all too keen to reference Europe's experience with colonialism in the event that Beijing is criticized for their actions. ${ }^{97}$ To Wang Yiwei, though 'Europe' was once a global/universal concept, today it is again regional, particularly because of the 'shifteastwards. ${ }^{98}$ While China seeks a partnership with the EU, and possibly to learn from it in certain ways, it has been unwilling to place itself in a position of recipient. ${ }^{99} \mathrm{~A}$ normative conception of EU power also underestimates the ability of Chinese values to shape international norms, particularly ironic in light of the EU's strong constructivist roots. Normative power theories seem to profoundly underestimate the possible constitutive role of norms exercised by emerging powers, especially given their appeal in other parts of the world..$^{100}$

Along with Chinese norms rooted in their exceedingly rich cultural traditions, containing, among others, elements of Confucian, Taoist and Buddhist traditions, there is also a model promoted by China of the relationship between state and citizen, as well as the layout of the world system. Sometimes informally referred to as the Beijing Consensus, this can be said to include norms of economic empowerment, sovereignty, non-interference, strong central government and state control in economic planning and economic operations. The system can be seen as a defence of countries with similar

\footnotetext{
${ }^{96}$ Mattlin, “A Normative EU Policy Towards China," 17; Laïdi, "BRICS," 617

${ }^{97}$ Fiott, Daniel, Interview with Julie Pickering, May 2012, Brussels

${ }^{98}$ Wang, "The Identity Dilemmas of EU Normative Power," 70

${ }^{99}$ Gustaaf Geeraerts, "China, the EU, and the New Multipolarity," European Review, 19:1 (2011): 57

${ }^{100}$ Part of this paragraph is based on an essay written for another class
} 
approaches to regional issues, such as defence and internal security. The $\mathrm{CCP}$ rhetorically promotes this system of values, norms and interests that legitimates its own ruling system, as seen most clearly in the Shanghai Cooperation Organization (SCO) and China's foray in Africa. It is also seen in the UN, as was the case in 2007, when China and Russia vetoed a UNSC resolution on Burma, which they qualified by claiming the country was not a threat to international stability, in direct challenge to Western traditions of civilian protection. ${ }^{101}$

However, it is important to not overestimate the idea that China is acting primarily as a normative power. Unlike the ideologically driven days of Mao, today China's foreign policy is deeply pragmatic. This includes its approach to the cooperation with the BRICS, which is based on China's perceptions of benefits to be gained from association which these countries, and not, per se, on wanting to go out of its way to benefit them. ${ }^{102}$ Rather, China participates in order to be able to defend its positions by referencing other large powers who hold those same positions, but it is not clear that they converge on many political issues and are in fact deeply heterogeneous. ${ }^{103}$ There are also questions about whether anything like the Beijing Consensus model actually exists. ${ }^{104}$ As well, despite calls for more representation in international institutions, China's contribution is still minimal, though it is increasing.

So, it is clear that the EU does, in fact, instrumentalize the normative narrative in certain ways, such as overt diffusion, cultural filter, contagion and informational diffusion through the use of a variety of institutions and instruments. It forms an

\footnotetext{
${ }^{101}$ Fox and Godement, $A$ Power Audit of EU-China Relations, 38

${ }^{102}$ Laïdi, "BRICS," 621

${ }^{103}$ Op. cit., 615, 621

${ }^{104}$ Renard, Thomas, Interview with Julie Pickering, May 2012, Brussels
} 
important part of its foreign policy identity, as seen through the creation of a broader narrative. However, there are serious problems with this, emanating from both a desire to gain economically from relations from China, and also from a certain impotence brought on by the EU's specific actorness or its lack of concentrated power.

\subsection{How do we distinguish norms from interests?}

How do we know when to distinguish norms from interests? Must they even be held as separate categories? According to many authors, normative power can go alongside other forms of power, like economic or military power. According to Laïdi, norms can include economic values, like free-market norms and regulatory norms, and there is no need to distinguish completely between "normes de marché" and "normes politiques."105

Because the EU itself seems to treat many economic values normatively, it can be problematic to keep the two separate in academic discussions. In fact, economic norms are often difficult to separate from ethical and socio-political norms, given that many socio-political norms are derivate of market/economic norms. In addition, there is always the risk of using normative justification for simple self-interest or strategic gains. So, in order to distinguish between the two as best one can, we can hold these values to be normative if they pass the basic test of firstly, being referenced normatively in the discourse, secondly, having this normative discourse generate actions and thirdly, being applied equally by the EU to its own member states and to foreign actors.

\footnotetext{
${ }^{105}$ Laïdi, "Les conséquences inattendues de la puissance européenne." Garnet Policy Brief, Centre D'études Européennes (December 2007): 3-4,6
} 
A case is made here that the EU's norms do not need to be purely ideational, but may also be consistent with norms of liberal economics and market regulation, such as accounting standards, banking regulations and competition standards. ${ }^{106}$

The values associated with liberal market economies are truly at the center of the EU single market project. They date back to the Treaty of Rome and have been used as measures of readiness in pre-accession negotiations. While these reflect very pragmatic beliefs based on self-interest, they can be said to fulfill the requisites to be considered norms, in that they are international in outlook and reference recognized codes of conduct, and are applied evenly. Many of these economic norms overwhelmingly reflect the logic of neoliberalist economic theory and free-market economics. Other norms reflect the necessity for social intervention in the market, such as core labour standards (CLS) or environmental protection, which ensure an economic system based on the rule of law and acting in accordance with other universal societal norms. Both reflect the EU's "embedded liberal focus." 107 These economic and market norms are no doubt imbued with some of the 'valueness' of traditional ideational norms, such as rule of law, human rights, and democracy. One can reference these in international covenants and treaties all the same, and their tenability is thought to be intrinsically universal and indivisible. They are viewed as legitimate, justifiable and their longevity is widely accepted. Yet they are also rooted much more in a material foundation, in that they are often inseparable from the EU's economic interests. The EU does have a well-organized and principled formulation of the best way a society should organize its economy, and the

\footnotetext{
${ }^{106}$ Laïdi, "Les conséquences inattendues de la puissance européenne," 3, 10

${ }^{107}$ Evert Faber Van Der Meulen, "Gas Supply and EU-Russia Relations." Europe-Asia Studies, $61: 5$ (July 2009): 841
} 
founding economic tenets of the integration project are held in high esteem. These norms can be said to represent the Union's raison d' être; they are at the core of the EU, both the very reason for its existence and the logic behind its maintenance. The consolidation of economic norms in the EU acquis was undertaken in 1992, which saw the legislating of over 300 acts, including technical product standards, competition policy and environmental legislation, among others. ${ }^{108}$

What does this do to the more idealist conception of Mannersian NPE? Manners clearly separates the norms he discusses, which are ideational in nature, from material roots. Aggestam sees this as a distinguishing factor between Manners' NPE and earlier works, notably Duchêne and Maull's civilian power, the latter linking ideational power to material incentives. ${ }^{109}$ Is it true that the EU espouses these norms with no claim to immediate self-interest? Laiidi claims that the EU does project these types of economic norms and values for their own sake. However, Youngs argues the norms embody strategic and economic interests, and Diez acknowledges the great difficulty in treating norms and interests as separate categories. ${ }^{110}$

The EU itself certainly uses a type of normative discourse in describing its economic and market values; there also exists, then, a narrative about the EU as a normative actor in the global economy and market-related regulation. This relates to the EU's discursive references to the important role it can play in the international arena as the establisher of international norms, standards and values related to economics and

\footnotetext{
${ }^{108}$ Gergana Nouchetva and Michael Emerson, "Economic Regimes for Exports: Extending the EU's Norms of Economic Governance into the Neighbourhood." Centre for European Policy Studies, Working Document, 233 (December 2005): 3

${ }^{109}$ Aggestam, “The World in Our Mind," 29

${ }^{110}$ Diez, "Constructing the Self and Changing Others," 622
} 
markets. A 2006 Commission publication, Global Europe-Competing in the World, argued that the EU "must play a leading role in sharing best practice and developing global rules and standards. To do so effectively we must also take account of the external dimension in making our regulatory and other standards" and support a "strong multilateral trading system." $"$ In a Commission document from 2007, A Single Market for $21^{s t}$ Century Europe, it explained part of its strategy as that of "expanding the regulatory space of the single market, by projecting our norms and values abroad, and further enabling European regulations to benefit from best practices everywhere, thus making European norms the reference for global standards." 112 The Commission states that it supports "pushing for the adoption of high quality standards....(such as on IFRS international accounting standards)." ${ }^{113}$ A Commission Staff Working Document, The External Dimension of the Single Market Review, further proposes that "the EU is emerging as a global rule maker" and that the single market is "a tool to foster high quality rules and standards." 114

If we accept that the EU can have economic and strategic norms, the question remains of how and whether this generates actions, or how the EU is trying to exercise normative power. Of course, the picture is less clear than it is with traditional ideational norms, since the EU is also often acting also in its own interest. Chad Damro proposed

\footnotetext{
${ }^{111}$ European Commission, Communication from the Commission, Global Europe: Competing in the WorldA Contribution to the EU's Growth and Jobs Strategy. \{SEC(2006) 1228\}\{SEC(2006) 1229\}\{SEC(2006) 1230\}, April 10, 2006, COM(2006) 567 final, 7-8, accessed February 2013, http://eurlex.europa.eu/LexUriServ/LexUriServ.do?uri=COM:2006:0567:FIN:EN:PDF

${ }_{112}$ European Commission, A Single Market for $21^{\text {st }}$ Century Europe, November 20, 2007, COM(2007) 724,3 , accessed January 2013 , http://eurlex.europa.eu/LexUriServ/site/en/com/2007/com2007_0724en01.pdf ${ }^{113}$ Op. cit., 11

${ }^{114}$ Chad Damro, "Market power Europe," Mercury, E-Paper, 5 (October 2010): 13, accessed January 2013, http://mercury.uni-koeln.de/fileadmin/user_upload/E-paper_no5_r2010.pdf
} 
the concept of Market Power Europe in 2010 to describe that the market and marketregulating serves as the EU's main identity, imbuing it with tools for projecting abroad and externalizing its policies, and how the EU both externalizes liberal economic norms and market intervention. ${ }^{115}$ They all contribute to the EU's efforts at 'managing globalization' by projecting norms that both suit its own interests and promotes the 'bestpractice' normative system.

In many ways the EU does instrumentalize these types of norms, such as through some of the economic tenets of the Copenhagen criteria and the Maastricht criteria on convergence to the European Monetary System. With the use of these systems, the EU has provided templates for accession countries or new members as to its economic requisites. These included the installation of a market economy, the ability to deal with competitive pressures and sound regulatory and enforcement systems. ${ }^{116}$ Accession negotiations are also an important way in which the EU establishes what its core standards are, and how a country ought to operate, and enforceable through a carrot-andstick approach to compliance. These economic norms are further evident in some of the EU's agreements and arrangements, such as the Cotonou, Euro-Med, 'GSP plus' system, Association Agreements and the Stabilization and Association Process (SAP) of the Western Balkans.

This is also seen in the EU's trade policies, and the way it instrumentalizes this power through its participation in global financial and international trade institutions, where it engages in both passive norm-exporting, through the sheer attraction of its

\footnotetext{
${ }^{115}$ Op. cit., 3-4

${ }^{116}$ Nouchetva and Emerson, "Economic Regimes for Exports," 8
} 
market-system, and more active forms of norm-exporting. ${ }^{117}$ The EU has historically been very active in these institutions, and where it bases its actions in these international platforms largely on its own experience as a single market. This experience is based on something between liberal market economics and a tradition in market-intervention; the EU's 'management of globalization' then becomes about shaping the system similar to its own, as seen in the EU's aggressive push for global regulatory convergence. ${ }^{118}$ Meunier and Nicolaïdis correctly identify that the EU is both an actor in trade- the structural power based on its sheer size and market power- and an actor through trade- which is derived from the fact that non-member states are eager to trade with the $\mathrm{EU}$, which gives Brussels bargaining power and the ability to often dictate the terms of the relationship to include, among other things, non-trade policy objectives. ${ }^{119}$ In its power through trade, however, Brussels reveals its willingness to play the part, and aggressively push for increasing amounts of liberalization, market access and social norms through its trade policy. ${ }^{120}$ Nicolaïdis and Howse go as far as claiming that the WTO is viewed as a possible forum for the "negative external spillover of many of the EU's internal policies, from agriculture to standardization, competition of the movement of people." ${ }^{121}$ This may also be occuring in bilateral FTA negotiations, which the EU views as an opportunity to gain leverage over smaller economies and bind in legal arrangements preferable to itself, in anticipation of the reigniting of WTO negotiations.

\footnotetext{
${ }^{117}$ Laïdi, "European preferences and their reception," 8

${ }^{118}$ Wade Jacoby and Sophie Meunier, "Europe and the management of globalization," 299 ; Laïdi, "Les conséquences inattendues de la puissance européenne," 8

${ }^{119}$ Sophie Meunier and Kalypso Nicolaïdis, "The European Union as a conflicted trade power," in The European Union and the New Trade Politics, Eds. John Peterson and Alasdair R. Young (London: Routledge, 2007) 112-131

${ }^{120}$ Alasdair R. Young, "Trade Politics Ain't What It Used to Be: The European Union in the Doha Round," Journal of Common Market Studies. 45:4 (2007): 798

${ }^{121}$ Diez, "Constructing the Self and Changing Others," 626
} 
Connecting the EU's ontological roots and its participation in multilateral institutions, the EU has emerged as a leader in global trade governance since the Uruguay Round, with one of the main effects being that it has agenda-setting powers. ${ }^{122}$ That round of negotiations was marked by the deepening of the trade agenda in a manner that was favourable to the EU, joining the US as the standard-bearer on economic norms. ${ }^{123}$ This kind of leadership also means it has a platform for promoting its economic norms in multilateral fora, such as the WTO, which it views as a space for this norm-projection. ${ }^{124}$ Countries like Denmark, Germany and Sweden have even at times treated the WTO as a forum for human rights promotion. ${ }^{125}$ At the WTO, the EU presses for a 'deep trade agenda' which combine commercial and social policies, including environmental, labour and consumer standards, all issues more typically associated with the EU's normative actorness. ${ }^{126}$ Some of the EU's economic norms are about economic regulation, seen in its support of the 'Singapore issues'- competition, investment, trade facilitation and government procurement. ${ }^{127}$ Despite much of Europe's protectionist history, particularly in the Southern countries, there is "growing acceptance of the benefits of free trade" throughout the EU. ${ }^{128}$ Other economic norms relate to the need to address market failures, which deal with the social side of regulation and market-intervention, such as environmental regulation and core labour standards, which resonate strongly with a European public who views them as integral considerations of trade-related policy. The

\footnotetext{
${ }^{122}$ Alasdair R. Young and John Peterson, "The EU and the new trade politics," in The European Union and the New Trade Politics, Eds. John Peterson and Alasdair R. Young (London: Routledge, 2007), 2

${ }^{123}$ Meunier and Nicolaïdis, "The European Union as a conflicted trade power," 117

${ }^{124}$ Op. cit., 121

${ }^{125}$ Op. cit., 803

${ }^{126}$ Young, "Trade Politics Ain't What It Used to Be," 799

${ }^{127}$ Op. cit., 789

${ }^{128}$ Op. cit., 791, 799
} 
calls for stricter environmental and labour codes at Uruguay compelled the participation of developing economies, many of whom perceived these items as discriminatory, given the relative low levels of development in their respective countries. ${ }^{129}$

Difficulty arises when the EU projects these market-oriented norms in the multilateral arena, because it can do so both out of consideration for social preferences and commitment to certain economic principles in EU member states, which have some of the highest standards in the world, and also out of self-interest. If EU member states retain these norms while third countries do not, the EU is at a competitive disadvantage, fuelling fears of a 'race to the bottom,' a fear that has led to calls for investor responsibility and common investment rules. ${ }^{130}$ The EU is particularly sensitive to this given the relative inflexibility of its market, in labour especially, in contrast to that of the US economy. Part of its motivation in instrumentalizing these norms is therefore possibly protectionist, since European firms cannot compete with lower standards in emerging markets. ${ }^{131}$ Likewise, some projects traditionally associated with ethico-normative, ideational motivations, such as good governance and rule of law projects currently underway in China, no doubt also have the interest of European economic actors in mind. Foreign companies cooperating in China have struggled with arbitrary rulings, politicized judiciaries, weak enforcement of already sometimes ill-defined property rights. A major problem is to distinguish whether the EU uses norms in its external trade policy, or is perceived to use them, because of their normative value and perceived universality in mitigating the negative impacts of globalization (i.e. to level the playing field, by moving

\footnotetext{
${ }^{129}$ Young and Peterson, "The EU and the new trade politics," 9

${ }^{130}$ Laïdi, "European preferences and their reception," 1; Young and Peterson, "The EU and the new trade politics," 7

${ }^{131}$ Laïdi, "European preferences and their reception," 7
} 
up, not down), or whether they are used as non-tariff barriers to trade, making demands on developing economies that they are in no way able to meet.

Nevertheless, the fact that they may be utilized in the name of self-interest does not necessarily disconnect these economic values from their normative roots if they are used as an end in themselves. As stated, because the EU is not a traditional actor in the military sense, it must rely on another kind of actorness, and one way it does this is by promoting its type of economic system abroad.

This relates to the EU's strategic norms, or rather, of norms being used strategically by the EU. Reacting to the rise of the BRIC countries and a potential existential crisis brought on by this, the EU is attempting to actively 'manage globalization' in a manner that benefits it and allows it to write the rules of the game. ${ }^{132}$ Seen in this light, the EU's normative power broadly is an attempt at asserting a narrative that keeps it relevant and in power, or in keeping with Manners, of literally establishing what normal is in the global economic system. ${ }^{133}$ By pushing for a highly-legalized variant of multilateralism rooted in international law and multilateral institutions, the EU is guaranteeing its role in the system, with an emphasis on areas in which it has some leverage: trade and economic policy. The EU can showcase its clout in forums like the WTO ${ }^{134}$ It is, then, also acting normatively in the sense that it is actively shaping or constructing the system rather than shaping itself to it. ${ }^{135}$ The EU's desire to shape what normal is then might be equally as much about strategic considerations by Brussels,

\footnotetext{
${ }^{132}$ Fiott, "The European Union's Normative Power in a Multipolar World," 10

${ }^{133}$ Manners, "Normative Power Europe," 236

${ }^{134}$ Zaki Laïdi, "Europe Bets on Norms Rather Than on Force," World Chinese Cross Currents, 4 :3 (2007): 30

${ }^{135}$ Fiott, "The European Union's Normative Power in a Multipolar World," 2
} 
based on both its ontological experience and its interests. The EU's preference for norms would include, along with a most genuine commitment to norms, the application of strategic thinking of its comparative advantage in world affairs. ${ }^{136}$

Of course, other ambiguities remain: while championing the cause of multilateral opening of markets, the EU maintains a double standard in a multitude of areas, notably the Common Agricultural Policy (CAP). The EU claims to be consistent in its internal and external trade actions, of leading par excellence, by example. ${ }^{137}$ Yet the colonial pasts of some member states contribute to the reticence to abandon the GSP systems, notably with the ACP countries, which renders it difficult for external actors to always view the EU as a sincere actor, and all contribute to making the EU a "conflicted trade power." 138

Another criticism put forward more recently is that the EU's recent economic downturn has led to questions of the lack of appeal of the EU model for third countries, and its 'loss of moral high-ground. ${ }^{139}$ The increasing irrelevance of Europe, and the West more generally, begs the question of why emerging powers would want to emulate the models. This is particularly true of the economic models, which proved to be so deeply flawed in the recent economic downturn, and has "challenged the view that the EU has a model for China." ${ }^{140}$ In light of this, commentators in China and even in Europe

\footnotetext{
${ }^{136}$ Mattlin, "A Normative EU Policy Towards China," 16

${ }^{137}$ Meunier and Nicolaïdis, "The European Union as a conflicted trade power," 125

${ }^{138}$ Op. cit., 113

${ }^{139}$ Mattlin, "A Normative EU Policy Towards China," 16

${ }^{140}$ Freeman, Duncan, Interview with Julie Pickering, May 2012, Brussels
} 
asked whether market-capitalism was the way to go, or whether there was merit to borrowing tenets of centralized economies from countries like China. ${ }^{141}$

The EU does have a normative narrative, which itself generates actions and instrumentalizations, but the question still remains whether it has much in the way of normative power. It passes a minimalist interpretation of discursively referencing norms, and having these norms generate actions. However, theories like that of Manners may overestimate the EU's ability to effectively shape and construct the ideas of others, especially if we use only ideational conceptions of norms. The EU may not actually have much normative power, especially if we use only ideational norms. However, the EU does seem to have some normative power to shape the behavior and actions of others- to 'produce intended effects'- if we look at its capacity to export norms and define standards about how economic systems ought to operate. The normative identity is then sometimes still maintained, despite widespread disbelief amongst many commentators that the EU could exercise anything normative towards China.

${ }^{141}$ Fiott, Daniel, Interview with Julie Pickering, May 2012, Brussels 


\section{Chapter: Case studies in EU-China Relations}

Three case studies have been selected- the human rights dialogue, Market Economy Status, and cooperation on Africa. These have been selected for two reasons. Firstly, they are areas covered directly by the EU and China in their official relations, found in either the political (human rights, African cooperation) or economic pillars (MES). As a result, these cases should allow for the examination of narratives in areas that have been explicitly selected by the two actors as areas of mutual interest and joint cooperation. Secondly, the three case studies provide examination of EU-China relations on very distinct policy areas. The first case study, that of the human rights dialogue, is an attempt to examine a sensitive bilateral policy area, explicitly normative, dealt with in the political/strategic first pillar of official EU-China relations, which the Europeans have historically made substantial reference to in their relations with China. This case allows for a deeper understanding of the EU's leverage in traditional normative policy areas. The second, the Market-Economy Status, allows for the examination of a policy area which is dealt with in the second pillar of the sectoral dialogues and has been a major irritant for the Chinese. Here we have a chance to investigate a policy area which is more technical and rooted in the EU's adherence to the multilateral trade regulation and its own internal economic norms. The third, EU-China cooperation in Africa, allows us to investigate the EU's adherence to the narratives in a policy area, also dealt with within EU-China relations, that is explicitly about international relations and global governance, rather than simply bilateral issues. 


\subsection{Human rights dialogue}

As shown earlier, human rights form an important component of the EU's narrative, its foreign policy discourse and specifically its policy towards China. Respect for human rights goes to the core of the EU project. In 1992, the EU formally integrated a variety of norms into its legal base through the Maastricht Treaty. ${ }^{1}$ Article 181 of the Treaty of Nice of 2001 stipulated that the objectives of improving human rights and developing democracy and rule of law should be sought through the union's economic and financial relations with third countries. ${ }^{2}$ This has been reiterated in the Amsterdam, Nice and Lisbon Treaties. The EU's Charter of Fundamental Rights, reinforced by Lisbon, outlines the principles that are indivisible and comprehensive for the citizens of the union.

In 2011, the document Human rights and democracy at the heart of EU external action-towards a more effective approach was adopted in an effort to improve the 'mainstreaming' approach to human rights. ${ }^{3}$ Again in 2012, High Representative Ashton announced the creation of a Strategic Framework on Human Rights and Democracy, which would work in close cooperation with the Special Representative on Human Rights, a new office opened in September 2012. A central part of his task is to work to promote human rights abroad and specifically to help this 'mainstreaming' of "human rights in all EU external policies."4

\footnotetext{
${ }^{1}$ Ibid

${ }^{2}$ Richard Balme, "The EU, China and human rights," in EU Foreign Policy in a Globalized World: Normative power and social preferences, Ed. Zaki Laïdi (London: Routledge, 2008): 144; Haydon, "Human rights and the development of EU-China relations," 10

${ }^{3}$ European Commission, Joint Communication, Human Rights and Democracy at the heart of EU External Action-towards a more effective approach, December 12, 2011, COM(2011) 886 final, 10-12, accessed May 2012, http://eur-lex.europa.eu/LexUriServ/LexUriServ.do?uri=COM:2011:0886:FIN:EN:PDF

4 "EU adopts Strategic Framework on Human Rights and Democracy Luxembourg."
} 
In 1989 the EC states responded swiftly to the brutal crackdown on protesters at Tiananmen. Sanctions were applied, diplomatic relations severed and the Commission published a statement condemning the massacre. Relations were reinstated in 1995, at which point the human rights dialogue emerged as the mechanism for dealing with the issue. ${ }^{5}$ Rather than direct confrontation, the EU selected the approach of 'mainstreaming' of human rights in all EU policies, including external relations, which is a fairly unique provision in international affairs. ${ }^{6}$ The dialogue was taken on as the forum in which these issues would be discussed, with the implicit understanding that the issues would not be dealt with elsewhere (like at the UNCHR). However, in analyzing the case of human rights in EU-China relations, and the human rights dialogue specifically, it becomes clear that it is not an entirely effective tool.

This normative policy has been officially instrumentalized in some shape or another in many of the EU's external relations. Since 1995, most cooperation agreements have included human rights clauses. ${ }^{7}$ In its relations with China, the Commission's 1995 policy paper affirmed the role of human rights in the relationship, explaining that "a commitment to human rights and fundamental freedoms is at the heart of EU policy worldwide. ${ }^{\prime 8}$ Again in the 2003 document, $A$ maturing partnership, a contrast is made between successful economic and strategic engagement and the human rights situation in China, which posed great cause for concern and over which "serious EU concerns remain." Today, the dialogue is viewed by the EEAS as "the Union's preferred channel

\footnotetext{
${ }^{5}$ Balme,"From Hard to Soft Power, and Return," 1

${ }^{6}$ Op. cit., 3

${ }^{7}$ Haydon, "Human rights and the development of EU-China relations," 10

${ }^{8}$ A Long Term Policy for China-Europe Relations

${ }^{9}$ A maturing partnership, 12
} 
for working to improve the human rights situation in China." ${ }^{10}$ In the 2006 communication, reference is made to the EU "supporting China's transition towards a more open and plural society."11

By the time the Commission began publishing communications specifically on China, the EU had taken on a different approach to China regarding human rights. Already in 1995, only 6 years after Tiananmen and the ensuing imposition of an arms embargo, the Commission communication stated that: "there is a danger that relying solely on frequent and strident declarations will dilute the message or lead to knee-jerk reactions from the Chinese government. To make progress, all the EU institutions should pursue human rights through a combination of carefully timed public statements, formal private discussions and practical cooperation," revealing the beginning of the 'constructive engagement' approach. ${ }^{12}$ By 1998 this change in tone was reinforced, with the Commission explicitly supporting 'dialogue' instead of confrontation. This is related in part to the shift away from using the United Nations Commission on Human Rights (UNCHR, today the Human Rights Council) to condemn Chinese violations, which began around 1996. Before this, the member states often had united positions towards China. ${ }^{13}$ France and Germany first began to favour not criticizing the Chinese in this forum, possibly in hope of gaining lucrative commercial deals, while the Nordic countries stood by their traditionally more hardline positions. ${ }^{14}$ For example, in 1997 Denmark put forward a bill co-sponsored by others against China at the UNCHR, which China reacted

\footnotetext{
10 "Human Rights Dialogue," Delegation of the European Union to China, accessed January 2013 http://eeas.europa.eu/delegations/china/eu china/political relations/humain rights dialogue/index en.htm ${ }^{11}$ EU-China: Closer partners, growing responsibilities, 4

${ }^{12}$ Haydon, "Human rights and the development of EU-China relations," 3

${ }^{13}$ Balducci, "The Limits of Normative Power," 42

${ }^{14}$ Ibid
} 
to by retaliating economically against Denmark and Sweden. ${ }^{15}$ At the 1998 General Affairs Council, it was stated that "in view of the first encouraging results of the EUChina human rights dialogue, the Council agreed that neither the Presidency nor member states should table or co-sponsor a draft resolution at the next UN Commission on Human Rights." ${ }^{16}$ This change of position was finally confirmed in 2000 when the Council instructed members states to stay neutral regarding a US-sponsored bill critical of China. $^{17}$

Human rights promotion have been a cornerstone (from the EU point of view) of its relationship with China, ever since the Tiananmen crackdown. ${ }^{18}$ The promotion of human rights is viewed as being a central part of the work done by the Commission and the delegation to China, yet from another perspective, human rights are the "perennial nuisance" in EU-China relations. ${ }^{19}$ This issue poses the biggest challenge to their relations, and has been rejected by many Chinese as the attempted imposition of Western 'hegemonic' ideas- it is really an area over which there is no clear value consensus. ${ }^{20}$ Chinese authorities assert that they have a different view of human rights, and that economic and social well-being, as well as collective rights, are as important as individual freedoms, which for them means something fundamentally different than the EU's position. ${ }^{21}$

\footnotetext{
${ }^{15}$ Mattlin, “A Normative EU Policy Towards China," 11

16 "The EU's Strategic Partnerships."

${ }^{17}$ Kenety, "Rights: EUUnlikely To Endorse U.S. Proposal To Censure China"

${ }^{18}$ Balme, "The EU, China and human rights," 146

${ }^{19}$ Mattlin, "A Normative EU Policy Towards China," 12

${ }^{20}$ Mattlin, "Thinking Clearly on Political Strategy," 97, 103

${ }^{21}$ Balme, "The EU, China and human rights," 151; Haydon, "Human rights and the development of EUChina relations," 2
} 
Despite the EU's official policy of 'mainstreaming' human rights into all its external policies and making this area a major component of the EU's relations with China, one very clearly sees that China is unwilling to blindly adopt externally-pushed norms. Though in 2003 the Commission wrote "human rights concerns have been given priority at the different levels within the political dialogue," in fact the trend was of increasingly confining these discussions to the forum of the human rights dialogue. ${ }^{22}$ The use of a human rights dialogue has been dubbed the EU's "sectoralization and containment" of human rights policy towards China. ${ }^{23}$ The idea behind this is best summarized by Jim Moran, Director of Asia at DG RELEX, who claimed that the EU and China's differences on human rights "should of course be respected, but given above all the strategic need that each side has of the other they should not be allowed to undermine the overall direction of the relationship." ${ }^{24}$ This approach suggests that the preferred method is not to risk strategic and economic interests over purely ideational motives. ${ }^{25}$ The downside to this strategy has been brought up by participants of the EUChina human rights seminar. A participant shared that the problem with the seminar was that it "is not sufficiently politically supported at the higher level of the EU ... so it's really a dialogue that is pursued in a small box that is isolated from the rest of EU-China relations. ${ }^{.26}$ Some authors have suggested that this is the realization by the EU that it must sideline and moderate its criticism of China if it wishes to benefit from a strong

\footnotetext{
${ }^{22}$ A maturing partnership, 7-9

${ }^{23}$ Balme,"From Hard to Soft Power, and Return," 31

${ }^{24}$ Renard, EU-China: Building Upon a Dialogue Among Strategic Partners, 11

${ }^{25}$ Balducci, "The Limits of Normative Power," 45

${ }^{26}$ "The EU-China Human Rights Dialogue: Perspectives from NGO Representatives," 10
} 
economic relationship, which has only been strengthened by the global recession and the Eurozone crisis, in which China is being called upon for financial help. ${ }^{27}$

The sectoralization and possible sidelining of this issue is revealed by a brief analysis of the EU policy papers, indicating a significant deterioration in mentions of human rights-related terms over the last decade. Mattlin notes that while around 50 such terms are found in the 2003 policy paper, down to nine in $2006 .{ }^{28}$ This deterioration has nothing to do with a qualitative improvement in the situation on human rights in China. For example, in 2008 the EU "voiced graved concern regarding the human rights and humanitarian situation in Tibet following recent events. China reiterated in detail its customary position on the situation... while noting that the door to further talks remained open." ${ }^{29}$ As recently as December 2012, High Representative Ashton urged the Chinese government to allow the free movement of journalists to Tibet and urged Beijing to respect the cultural, political and social rights of Tibetans in a declaration regarding recent self-immolations in Tibet. ${ }^{30}$ There has also been a failure on the part of the Chinese to ratify the International Covenant on Civil and Political Rights, which has been one of the EU's biggest requests. ${ }^{31}$

\footnotetext{
${ }^{27}$ Mattlin, “A Normative EU Policy Towards China," 6; The last two sentences are based on an essay written for a separate class

${ }^{28}$ Mattlin, "A Normative EU Policy Towards China," 13

${ }^{29}$ Council of the European Union. EU Annual Report on Human Rights 2008. November 27, 2008. 14146/2/08, REV 2, COHOM 105 : 30, accessed December 2012, http://www.consilium.europa.eu/uedocs/cmsUpload/st14146-re02.en08.pdf

${ }^{30}$ Council of the European Union. Declaration by the High Representative, Catherine Ashton, on behalf of the European Union on Tibetan self-immolations. 14 December 2012. 17831/1/12 REV 1, PRESSE 535, accessed February 2013, http://www.consilium.europa.eu/uedocs/cms data/docs/pressdata/en/cfsp/134378.pdf

${ }^{31}$ "Le dialogue sur les droits de l'homme." France Diplomatie, Ministère des Affaires étrangères. 20 Septembre 2012, accessed January 2013, http://www.ambafrance-cn.org/Le-dialogue-sur-les-droits-de-lhomme.html ; this sentence was taken for an essay written for a different class
} 
China and the EU now hold semiannual human rights dialogue meetings, during which various parties meet to discuss concerns, alternating between an EU capital and Beijing. ${ }^{32}$ These meetings are institutionalized, regular and uniquely devoted to human rights, unlike most of the EU's human rights dialogues, which are either ad hoc or brought up within broader dialogues. ${ }^{33}$ The dialogue has two components. In the first, Chinese and European officials meet in private. In addition, there is a more inclusive seminar that involves legal experts, academics and NGOs from both sides. ${ }^{34}$

Nevertheless, both are fairly closed affairs and information on the inner-workings is hard to come by.

The human rights dialogue between the EU and China has received mixed reviews. The EU position is that it is a dialogue in which both sides review the human rights situations in the other, present best practices, and discuss ways to learn from each other. To the EU, the human rights dialogue is successful because it provides them access to higher-levels of the Chinese government.

In practical terms, the EU seeks to make the human rights dialogue resultsoriented and measurable in concrete terms. ${ }^{35}$ The EU has been able to identify some major 'wins' in China's human rights regime, though it is not clear whether pressure on China from other actors, chiefly the US, had a bigger role to play. These include China's signing of the second covenant of the UN Convention on Civil and Political Rights and

\footnotetext{
32 "The EU-China Human Rights Dialogue: Perspectives from NGO Representatives," Human Rights In China (HRIC) China Rights Forum, Engaging Engagement: Conversations and Reflections, 3 (2010), accessed in October 2012, http://www.hrichina.org/content/3263, 1

33 "Les réalisations des PESC: L'action de l'Union européenne en faveur des droits de l'homme et de la démocratie." France Diplomatie, Ministère des Affaires Etrangères, accessed February 2013. http://www.diplomatie.gouv.fr/fr/europe-828/union-europeenne-et-monde/politique-etrangere-et-desecurite/les-realisations-de-la-pesc/

34 "The EU-China Human Rights Dialogue: Perspectives from NGO Representatives," 2

${ }^{35}$ EU-China: Closer partners, growing responsibilities, 4
} 
the UN Covenant on Social, Economic and Cultural Rights. ${ }^{36}$ As well, in the last two years the Chinese have reduced the number of crimes that can lead to the death penalty, which has been a reoccurring request from the Europeans. ${ }^{37}$

The ideas promoted by the EU through the human rights dialogue are often applied and enforced through the Commission's work, including through the EU delegation in Beijing, albeit in different forms. Projects run by the delegation involve a Village Governance Program and the EU-China Legal and Judicial Co-operation Programme, through which training exercises are provided for judges. ${ }^{38}$ These projects are perhaps viewed as roundabout ways of working for the amelioration of human rights in China, operating in forms that are acceptable to the CCP, though these have also been given very mixed reviews. ${ }^{39}$

Critics see the EU-China human rights dialogue as a failure. Representatives from major NGOs, including Amnesty International and Human Rights Watch as well as the European Parliament, have raised concerns with the dialogue. ${ }^{40}$ A 2007 European Parliament report noted many of the problems with the dialogue, including that there has been a qualitative deterioration in the human rights situation since the Chinese have been engaged with Europe on these issues. ${ }^{41}$ The European Parliament has been very active on

\footnotetext{
${ }^{36}$ Men and Balducci, "EU-China Relations in the 21st Century," 26

${ }^{37}$ Vaïsse and Kundnan, "European Foreign Policy Scorecard 2012," 35

${ }^{38}$ Balme, "From Hard to Soft Power, and Return," 5; "Human Rights Dialogue," Delegation of the European Union to China, accessed January 2013 http://eeas.europa.eu/delegations/china/eu china/political relations/humain rights dialogue/index en.htm ${ }^{39}$ Freeman, Duncan, Interview with Julie Pickering, May 2012, Brussels; "The Limits of Normative Power Europe in Asia," 47-48.

${ }^{40}$ Haydon, "Human rights and the development of EU-China relations," 14

${ }^{41}$ European Parliament, The Human Rights Dialogue Between the EU and China, Briefing Paper, October 2007: 12, accessed May 2012, http://www.europarl.europa.eu/committees/en/droi/studiesdownload.html?languageDocument=EN\&file=18 550; Haydon, "Human rights and the development of EU-China relations," 3
} 
human rights abuses in China, and passed a resolution after the 2007 dialogue that it "regrets the fact that once again the Council and Commission have failed to raise in a firm manner human rights issues at the EU-China Summit in order to give more political weight to human rights concerns. ${ }^{, 42}$ The European Parliament has raised these concerns during the biannual interparliamentary meetings (IPMs) between the parliament's China delegation and the National People's Congress of China. ${ }^{43}$ Member of Parliament Van de Camp, member of the parliament's Chinese delegation, conveyed that he is not sure of the intentions of the Chinese partners when they come to the table to discuss these issues and has not noticed any change in position in the three years he has been in Brussels. ${ }^{44}$

The European side is frustrated with their Chinese counterparts, and problems with the dialogue have been acknowledged by the $\mathrm{EU} .^{45}$ The 2006 Commission paper concludes that "the EU's expectations...are increasingly not being met" and called for the human rights dialogue to be "more focused and results-oriented. ${ }^{, 46}$ There is doubt about whether this kind of dialogue will actually achieve anything. ${ }^{47}$ The content itself is watered down to accommodate the Chinese side. At the seminar portion of the dialogue, criticism has been made of the ability and willingness of Chinese NGO representatives and academics to exchange basic information. ${ }^{48}$ Sophie Richardson of Human Rights Watch, who participated in the expert seminar, commented that she "can't say that it has

\footnotetext{
${ }^{42}$ European Parliament. European Parliament resolution of 13 December 2007 on the EU-China Summit and the EU/China human rights dialogue. 2007/2678(RSP), accessed March 2013, $\mathrm{http}: / / \mathrm{www}$.europarl.europa.eu/sides/getDoc.do?type=TA\&reference=P6-TA-2007-0622\&language=EN

${ }^{43}$ European Parliament, "Delegation for Relations with the People's Republic of China," Accessed February 2013. http://www.europarl.europa.eu/meetdocs/2009 2014/documents/d$\mathrm{cn} / \mathrm{dv} / 789 / 789139 / 789139 \mathrm{en} . \mathrm{pdf}$

${ }^{44}$ Van de Camp, Wim, Interview with Julie Pickering, May 2012, Brussels

${ }^{45}$ Men and Balducci, "EU-China Relations in the 21st Century," 26

${ }^{46}$ EU-China: Closer partners, growing responsibilities, 4-5

${ }^{47}$ Freeman, Duncan, Interview with Julie Pickering, May 2012, Brussels

48 "The EU-China Human Rights Dialogue: Perspectives from NGO Representatives," 5
} 
really led to groundbreaking change with any of those communities (Chinese NGOs and academics) in terms of progress on any of these issues."

The Chinese are willing to continue to meet in this form possibly as a concession in return for an implicit understanding that the EU shall no longer raise Chinese human rights violations at the United Nations Commission for Human Rights. ${ }^{50}$ This was tested, as aforementioned, in 1997, when the Chinese halted the dialogue in response to a tabling of a critical resolution. ${ }^{51}$

A fairly major normative disconnect on this policy area also prevents very effective dialogue: there is the view from Beijing, held by many Chinese citizens, that the promotion of Chinese human and minority rights by an external actor is an intrusion into China's internal affairs, and by default, on its sovereignty. The Chinese leadership has vocally showcased a conception of human rights based on economic and social wellbeing, rather than political and civil rights. ${ }^{52}$ This is justified as necessary for China's internal development and to make the country's rise peaceful and stable. ${ }^{53}$ While Brussels often links the ethos of multilateralism and supranationalization to principles corresponding to basic human liberties and universal freedoms, Beijing accepts a much more constrained definition. As previously shown, the norm of sovereignty figures prominently in Chinese foreign policies, such as the "new security concept" and "democratization of international relations," and China has shown itself willing to strictly

\footnotetext{
${ }^{49}$ Op. cit., 7

${ }^{50}$ Mattlin, "A Normative EU Policy Towards China," 12

${ }^{51}$ Jian, "A Clash of Civilization?" 73

${ }^{52}$ Balme, "From Hard to Soft Power, and Return," 6

${ }^{53}$ Part of this paragraph is based on an essay written for another class
} 
enforce its norms. ${ }^{54}$ This is noticeable in its resolute upholding of the One-China principle and recognition of China's rights to Xinjiang and Tibet, which are 'nonnegotiables' for relations with the country. Premier Jiang Zemin reiterated that "to maintain national independence and safeguard sovereignty will be the supreme interests of each government and people." He further proposed an alternative approach to human rights, arguing that "without sovereignty there will be no human rights to speak of." 55

The defence of China's sovereignty is clearly demonstrated in the case of the EU. Angela Merkel's meeting with the Dalai Lama in 2007 resulted in Beijing cutting off all contacts. ${ }^{56}$ Nicolas Sarkozy's meeting with the Dalai Lama led to threats from Beijing and eventually, the last minute cancelling of the annual EU-China summit of 2008 during the French presidency. ${ }^{57}$ Again when Sarkozy refused to commit to attending the Beijing Olympics of 2008, there was a state-permitted boycotting of French supermarket giant Carrefour stores in China, as well as those of other French retailers in $2008-2009 .^{58}$ In these cases, the Chinese authorities defend their norms of sovereignty, internal and external, and resist any attempt to challenge them, which is both viewed as an insult and a 'deal-breaker'. 59

\footnotetext{
${ }^{54}$ Pan, "Managing the conceptual gap on sovereignty in China-EU relations," 232

${ }^{55}$ Bates Gill, Rising Star: China's New Security Diplomacy (Washington D.C.: The Brookings Institute, 2007): 110 ; This paragraph is based on an essay written for a different class

${ }^{56}$ Fox and Godement, $A$ Power Audit of EU-China Relations, 35

57 "Rencontre historique entre Sarkozy et le dalaï-lama," Le Figaro, December 6, 2008, accessed February 18, 2013, http://www.lefigaro.fr/international/2008/12/06/01003-20081206ARTFIG00696-premiererencontre-entre-sarkozy-et-le-dalai-lama-php; Chan, "Images, visibility and the prospects," 142; "Barroso annonce un sommet UE-Chine pour "bientôt"," Le Monde, January 30, 2009, accessed March 2013, http://www.lemonde.fr/europe/article/2009/01/30/barroso-annonce-un-sommet-ue-chine-pourbientot 1148502 3214.html

${ }^{58}$ Pan, "Managing the conceptual gap on sovereignty in China-EU relations," 239; Fox and Godement, $A$ Power Audit of EU-China Relations, 35

${ }^{59}$ Part of this paragraph is based on an essay written for another class
} 
Unfortunately, the human rights dialogue is looking increasingly like an empty shell. A participant of the EU-China seminars called them a "waste of time and money.",60 When the EU does instrumentalize the norms into its relations with China, it is restricted to a forum that is contained and fairly restrictive from the public. On the Chinese side, presently its participation seems to be solely about assuaging international criticism. ${ }^{61}$ Narratives:

Is it possible to recognize the narratives here? A variety of logics of the strategic partnership do seem to apply somewhat in this case, and certainly we can see that the EU uses both discourses and discursively defends the narratives. Through the 'sectoralization' of human rights within EU-China relations, the EU essentially has worked to contain this sensitive issue and not let it negatively impact other areas, possibly considered more important. After the $9^{\text {th }}$ EU-China Summit in 2006, a media release by the EU stated that "the two sides... reaffirmed their commitment to further enhance cooperation and exchanges in this field on the basis of equality and mutual respect. ${ }^{, 62}$ There was an intentional shift away from an earlier policy of confrontation, best seen in the imposition of the arm's embargo and the member states' resolutions in the UNCHR. The pattern of 'sectoralizing' falls in line with the interest-based and multisectored nature of the strategic partnership. This may also explain the fact that discursive references to human rights have declined somewhat in official policy papers to China. This is clearly also the use of the strategic partnership as a tool for discussing human rights- by providing a narrative around relations that are broad and encompassing of

\footnotetext{
60 "The EU-China Human Rights Dialogue: Perspectives from NGO Representatives," 8

${ }^{61}$ Haydon, "Human rights and the development of EU-China relations," 31

62 "Ninth EU-China Summit," 3
} 
many policy areas, the EU is possibly better able to justify broaching this issue. It also corresponds to the strategic partnership's impetus of legitimizing the EU, in that the EU portrays itself as an important actor in human rights promotion and the international human rights regime.

The ability to sectoralize is of particular importance to Beijing, who without a doubt views the dialogue as a political concession to the Europeans and a way of avoiding spillover of this sensitive issue.$^{63}$ Also referred to as compartmentalizing, this allows the two sides to reference the principle of human rights and norm-promotion while also undertaking more fruitful projects separately. ${ }^{64}$ However, more cynical interpretations view the EU as being able to maintain and defend its normative identity without having this issue becoming a major part of its relations with China, given that these issues are very contained by the dialogue format. ${ }^{65}$

The EU-China human rights dialogue also follows the logic of the strategic partnership narrative in that it officially endorses equality of partners and equality of their positions. The Chinese are as prepared as the Europeans to criticize perceived human rights violations taking place in Europe, and this type of reciprocity is understood as being a part of the process. ${ }^{66}$ The dialogue model, by promoting discussion on both sides in a non-confrontational manner, may in fact prove to be a form of recognition of the existence of competing normative systems. ${ }^{67}$

\footnotetext{
${ }^{63}$ Fox and Godement, A Power Audit of EU-China Relations, 34

${ }^{64}$ Mattlin, "A Normative EU Policy Towards China," 14; Haydon, "Human rights and the development of EU-China relations," 3

${ }^{65}$ Haydon, "Human rights and the development of EU-China relations," 3

${ }^{66}$ Freeman, Duncan, Interview with Julie Pickering, May 2012, Brussels

${ }^{67}$ Balme,"From Hard to Soft Power, and Return," 4
} 
It has also been widely suggested that the EU recognized the lack of effectiveness of a sanctions-based human rights policy towards China, demonstrated by the arms embargo placed post-Tiananmen. ${ }^{68}$ As a result, the EU is ascribing more to the strategic partnership narrative in engaging China constructively rather than through confrontation. It has opted for a soft power approach involving a dialogue of equal partners in the truest sense of the word, which can be contrasted to a hard power normative policy, which was exemplified by the arm's embargo of 1989 as a response to Tiananmen. ${ }^{69}$

However, this narrative is also problematic. For example, there is minimal mutual understanding between the two actors on this issue, and little to believe that the Chinese are coming to the table out of their own volition. At least officially, there is no real convergence or mutual understanding in this case.

The extent to which it has borne results is also very questionable. As mentioned, some have argued there has been a qualitative deterioration of the human rights situation in China since the early 2000 s, despite being engaged in a variety of dialogues. ${ }^{70}$ Antoine Madelin of the International Federation for Human Rights (FIDH) wrote of his experience in the seminar portion of the dialogue: "the chief impediment is that the EU is blocked by the Chinese (...) from adopting these (European NGO) recommendations. And this has progressively inhibited EU initiatives to improve the seminars for the sake of ensuring 'successful discussions."

In addition, the dialogue yet again reveals the lack of cohesiveness of the EU policy towards China, revealing the limitations of the EU's legitimation exercise. The

\footnotetext{
${ }^{68}$ Ibid

${ }^{69}$ Ibid

${ }^{70}$ Haydon, "Human rights and the development of EU-China relations," 13

71 "The EU-China Human Rights Dialogue: Perspectives from NGO Representatives," 5
} 
member states view the dialogue as a useful mechanism for maintaining these more controversial discussions at the EU-level, thereby keeping the potential controversy out of strictly bilateral relations, which Mattlin argues is visible in the actions of French, German and British politicians supporting the dialogue when it was first created. ${ }^{72}$ For example, the position of the French government, explained in Beijing by former President Chirac, is that the dialogue is best held at the European level because of common EU values. ${ }^{73}$ This criticism is not comprehensive, however, given that Germany and the UK both have their own human rights dialogues with China that complement the EU's. ${ }^{74}$

The strategic partnership narrative then seems to be generated to a certain extent in this case. The dialogue format suggests actualization of the idea of equality of partners, as well as of the focus on an interest-based EU-China partnership in which sensitive issues ought to not interfere with broader interests, as seen in the compartmentalization or sectoralization of human rights in these relations. However, this policy area is clearly of more importance to the EU than the Chinese, putting into question the idea of mutual understanding between the two partners. This lack of mutual understanding is intensified by the problem of apparent absence of cohesiveness amongst the member states and the question of the extent to which cooperation on this issue has actually born results, illustrating ambiguities and difficulties with the implementation of this narrative.

When applying the narrative of normative actorness, the picture is also mixed. Discursively there is a strong attachment to the normative narrative. In some ways it may signal a success on the part of the EU, in that the EU has succeeded in initiating and

\footnotetext{
${ }^{72}$ Mattlin, "A Normative EU Policy Towards China," 14; Balducci, "The Limits of Normative Power Europe," 51

${ }^{73}$ " Le dialogue sur les droits de l'homme."

${ }^{74}$ Balducci, "The Limits of Normative Power Europe," 49-50
} 
maintaining a dialogue of this nature- of actually instrumentalizing- with an autocratic country very defensive about its internal affairs. Despite calls by the Chinese for cultural relativism, there is international consensus that the Chinese government violates the rights, understood very broadly, of its own citizens, and so the existence of a dialogue on the subject confirms that this area is being dealt with on some level, however restricted its results or impacts may be. Another way of looking at the policy of constructive engagement through compartmentalization is that confrontation will only worsen relations between the two, and so this is the only type of engagement that is really acceptable, particularly given the EU's lack of leverage in forcing Beijing to adopt anything else. ${ }^{75}$

In support of the normative narrative in human rights, a strong case can be made that long-term socialization can occur through these kinds of iterative discursive practices, particularly through the meeting of Chinese academics and NGO representatives in one of the forums.

In the case of the human rights dialogue, it has been shown that the EU really does not have any leverage (or is not perceived to), given the low saliency of the issue for Beijing and more importantly that the EU has shown through its sectoralization and constructive engagement that it is not willing to risk having this sensitive issue 'spillover' into others. The EU's trade leverage or leverage in international negotiations is not utilized here or made conditional on compliance of the international human rights regime, which creates conditions in which the Chinese do not need to agree to anything. In instances when the EU might have used leverage, such as WTO accession negotiations, it

\footnotetext{
${ }^{75}$ Haydon, "Human rights and the development of EU-China relations," 29
} 
consciously chose to not engage China on its human rights. In fact, Trade Commissioner at the time Leon Brittan endorsed a less confrontational approach to human rights, which gave the Commission a 'carte-blanche' to separate human rights from trade negotiations. $^{76}$

In practice, sectoralization can also be seen as the opposite of the EU's stated mainstreaming approach because it isolates human rights from almost every single other policy area. Rather than allow access to the European market conditional on improvement of human rights conditions, fruitful trade and economic relations are allowed to flourish despite no shift in the latter. Still, this tactic may allow for some engagement of this issue while the two actors continue to build up other areas. The EU also has no real leverage on China in this policy area because it desperately wants to gain economically from the relations, and its member states have shown in the recent economic downturn no desire to upset their partners, who are seen as crucial to the continent's economic recovery. ${ }^{77}$

The fact that the EU's discursive narrative of human rights towards China seems to have declined somewhat begs the question of whether the broader normative narrative has weakened, and whether the EU is choosing to defend economic interests and stop pushing normative issues that are sensitive to the third country. However, the existence of the human right dialogue, and the references to human rights violations by the various EU officials and the parliament demonstrate the existence of normative actorness. Still, this does not translate into normative power in this precise case with China. Furthermore,

\footnotetext{
${ }^{76}$ Balducci, "The Limits of Normative Power Europe," 46

${ }^{77}$ Vaïsse and Kundnan, "European Foreign Policy Scorecard 2012," 35
} 
this is a clear case where norms can be thought of as distinct from interests, since even the EU is not willing to jeopardize its interests by inserting conditionalities.

Some have argued that the 'civilizational limits' of the EU's normative narrative are what prevent the dialogue from being effective ${ }^{78}$ The official Chinese stance is that human rights are fundamentally about internal sovereignty, and that criticism of its conduct is tantamount to a violation of its sovereignty ${ }^{79}$ Even using a broad definition of fundamental rights as expressed in the UN Universal Declaration of Human Rights, the Chinese government cannot use a relativist defense; it is widely accepted that Beijing continues to violate the rights of its citizens. The official reception by the Chinese also highlights the problems of normative disconnect/normative gaps, though it is difficult to ascertain given the nature of the Chinese regime.

The case study of the human rights dialogue reveals the ambiguity between the two narratives in their implementation. The normative narrative is strongly present at the discourse level, and as well it is seen to generate actions. Nevertheless, the case allows us to see the difficulty associated with achieving any type of normative power towards China. As well, the discourse itself may have been watered-down, leading to a weakening of the narrative itself independent of its instrumentalization. As for the strategic partnership narrative, there is reason to believe that the case of the human rights dialogue indicates some of this logic as well, specifically when taking into consideration the factors that led to its adoption.

\subsection{Market Economy Status}

\footnotetext{
${ }^{78}$ Wang, "The Identity Dilemmas of EU Normative Power," 73

${ }^{79}$ Freeman, Duncan, Interview with Julie Pickering, May 2012, Brussels
} 
On the trade front, the EU is a well-experienced and strong actor, and it has been a fervent advocate of the global trade system. In its actions within the WTO, the EU has continuously pushed for a deepening of the trade agenda, and acts like the 'globalizer' in international trade ${ }^{80}$ For the Chinese, the EU's support in its accession to the WTO was symbolically important, and their trading relationship has since flourished tremendously. ${ }^{81}$ Still, the EU is keenly aware of problems facing their economic and trade relations with China. There are a number of areas in the trade relations that are contentious, in particular the trade deficit, which many in the EU perceive to be related to unfair competition. China is also the number one country affected by the EU's antidumping measures. ${ }^{82}$ The issues of weak protection of intellectual property rights and heavy state interference in industry capital allocation and pricing restrictions are also problematic. ${ }^{83}$ They have been particularly antagonistic because the EU argues it restricts access for European businesses in the Chinese market as well as trade in its goods and services, which contributes to the trade deficit. ${ }^{84}$ In particular, the EU would like to see Beijing keep its obligations in order to protect EU businesses operating in China and exports to China, saying that while Chinese tariffs have gone down since its accession to

\footnotetext{
${ }^{80}$ Meunier and Nicolaïdis, "The European Union as a conflicted trade power," 121

${ }^{81}$ Représentation permanente de la France après de l'Union Européenne. "Les Relations UE-Chine." Accessed on March 30 2013. http://www.rpfrance.eu/Les-relations-UE-Chine.html

${ }^{82}$ European Commission. Commission staff working document, Accompanying the document, 'Report from the Commission to the European Parliament - 29th Annual Report from the Commission to the European Parliament on the EU's Anti-dumping, Anti-subsidy and Safeguard activities (2010) \{COM(2012) 59 final\}'. February 16, 2012. SWD(2012) 9 final, 22, accessed February 8, 2012. http://trade.ec.europa.eu/doclib/docs/2012/may/tradoc 149395.pdf

${ }^{83}$ Pierre Defraigne, "The World Trade Organization," in China-EU, A Common Future, Eds. Stanley Crossick and Etienne Reuter (Singapore: World Scientific Publishing Co., 2007): 164

84 "Fact sheet on trade relations."
} 
the WTO, "EU exports still face a number of tariff and non-tariff barriers to trade and restrictions on investment" in China. ${ }^{85}$

According to the EU, part of the problem is that China is not fulfilling all of its obligations under its WTO agreement, and has not put the measures in place to be considered a fully operational market economy. ${ }^{86}$ As a result of these concerns over China's trading practices, the EU continues to deny granting Market-Economy Status (MES) to China. ${ }^{87}$ Trade Commissioner Karel De Gucht is considering initiating trade defence measures against Chinese telecommunications giant Huawei on behalf of the Commission, though EU practice is that opening investigations should be the prerogative of member states or community-wide industries. ${ }^{88}$ Though the EU's granting of MES is not explicitly a WTO matter, the issue is closely related more broadly to China's recent inclusion in that organization. ${ }^{89}$ The Uruguay Round of WTO negotiations established the Anti-Dumping Agreement (ADA), which set out the definition and criteria of dumping, as well as procedure for investigation and actions, currently used by its members. ${ }^{90}$ China's major trading partners have also not granted MES, including the US, Canada and Japan, though as of September 2011, China has been granted MES by 81 countries,

\footnotetext{
${ }^{85}$ Zhang Jiao, "The EU-China Relationship Arriving at a Bottleneck," 5; Document Accompanying $\operatorname{COM}(2006) 631$ final, 7

${ }^{86}$ Document Accompanying COM(2006) 631 final, 8-10

${ }^{87}$ Wu Liming. "Commentary: Time for EU to recognize China's market economy status," Xinhua net, September 14, 2011, accessed February 82012 , http://news.xinhuanet.com/english2010/indepth/2011-09/14/c 131138759.htm

${ }_{88}$ Joshua Chaffin, "EU berates China on steel subsidies," Financial Times, January 14, 2013, accessed February 27 2013, http://www.ft.com/intl/cms/s/0/6d4e6408-5e68-1/e2-b3cb00144feab49a.html\#axzz2KLqwLF00

${ }^{89}$ Li Jinshan, "Market Economy Status," in China-EU, A Common Future, Eds. Stanley Crossick and Etienne Reuter (Singapore: World Scientific Publishing Co., 2007): 171

${ }^{90}$ World Trade Organization, "Uruguay Round Agreement: Agreement on Implementation of Article VI of the General Agreement on Tariffs and Trade 1994," accessed March 2013, http://www.wto.org/english/docs e/legal e/19-adp 01 e.html
} 
including New Zealand (the first, in 2004), Singapore, Malaysia, Australia, Russia and Switzerland. ${ }^{91}$

For the Chinese, this is a major irritant and it has taken center stage in many highlevel meetings. ${ }^{92}$ It is a point considered unfair by the Chinese public, and makes frequent appearances in Chinese online newspapers, and for Beijing, it is considered a political issue more than a technical one. ${ }^{93}$ It is a concern primarily because it widens the definition of the dumping margin, according to which trading partners could apply antidumping measures. These measures, in the form of duties, are applied in cases where it has been proven by the EU, according to WTO-approved standards, that dumping has occurred, i.e., external firms are exporting goods into a country at prices below market prices and/or below the average cost of production. ${ }^{94}$ In practical terms, MES only has a real impact in matters of anti-dumping. If a country is not considered a market economy, the importing country, under WTO law, is able to define the normal value of exports emanating from that country. It bases this normal value on an 'analogue country', which is a market economy with an industry that is thought to be analogous with the industry operating in the economy in question. This depends on the industry in question, though India is often used as an analogue market. ${ }^{95}$ To the Chinese, this is frustrating given that

\footnotetext{
91 "No need to nitpick over China's market economy status," People's Daily, September 28, 2011, accessed in October 2012, http://english.peopledaily.com.cn/90780/7606975.html; Wolfgang Klenner, "Economic Relations between the EU and China: Evolution of an Exclusive Partnership." China: An International Journal, 3:2 (September 2005): 343

${ }^{92}$ Berkofsky, "EU-China Relations."

${ }^{93}$ Ding Yifan,"The World Trade Organization- China perspective," in China-EU, A Common Future, Eds. Stanley Crossick and Etienne Reuter. (Singapore: World Scientific Publishing Co., 2007): 169; "China pledges unconditional support to EU in debt crisis," Xinhua English News, September 20, 2011, accessed October 2012, http://news.xinhuanet.com/english2010/china/2011-09/20/c 131149164.htm; Freeman, Duncan, Interview with Julie Pickering, May 2012, Brussels

${ }_{94}^{94}$ Klenner, "Economic Relations between the EU and China," 342

${ }^{95}$ Op. cit, 343
} 
the prices in analogous economies are often higher than the actual Chinese value of production of goods. This inflated value, from a Chinese perspective, is then compared to the export price of the good, after which an assessment can be made of whether dumping has taken place.

Within DG Trade there is a working group on MES, created in 2004 to monitor China's progress towards the realization of a market economy, organized under the EUChina Strategic Partnership's Pillar II, the Economic and Sectoral Dialogue. The group meets regularly in Brussels and in Beijing, where it consults with its Chinese counterparts. ${ }^{96}$ To the EU, not granting the Chinese MES is officially a purely technical matter, and it is not conceived of as a political bargaining chip. ${ }^{97}$ The EU uses five criteria to judge the readiness to grant MES, as set out in the antidumping regulation. ${ }^{98}$ Their criteria are closely related to those currently used to establish whether accession countries can be considered to be market-economies under the Copenhagen economic criteria. ${ }^{99}$ These are: absence of barter trade and absence of state-induced distortions in the operations of enterprises linked to privatization; degree of government influence, including through tax discrimination; adequate corporate governance, especially regarding accounting standards; transparent rule of law to ensure property rights and operation of a bankruptcy regime; and a financial sector that operates independently of the state. ${ }^{100}$

\footnotetext{
${ }^{96}$ Progress by the People's Republic of China towards graduation to market economy status, 4

97 "Fact sheet on trade relations."

${ }^{98}$ Working document, Accompanying $29^{\text {th }}$ Report from the Commission, 16

${ }^{99}$ European Commission. "Progress towards meeting the economic criteria for accession: the assessments of the 2011 Progress Reports and the Opinion (Serbia)." Directorate-General for Economic and Financial Affairs, European Economy, Occasional Papers, 85 (December 2011): 2

100 "Fact sheet on trade relations."
} 
DG Trade argues that according to these criteria, the Chinese do not fulfill the minimum conditions. A Preliminary Assessment on granting MES to China was conducted in 2004 by the Commission after an official request made in 2003 by the Chinese authorities to review the status. ${ }^{101}$ The Commission concluded that it was not possible to grant this status to China, given shortcomings in the following areas: state influence, corporate governance, property and bankruptcy law and the financial sector. ${ }^{102}$ Again in 2006, it was judged that "the conditions... are not fulfilled." ${ }^{103}$ In an official Commission report of 2008, it was noted that China had worked hard to fulfill certain criteria, namely implementing new intellectual property, bankruptcy and anti-monopoly laws, as well as the new accounting standards. Nevertheless, the report concluded that the economy was still deeply distorted by significant state intervention in industry and the financial sector. ${ }^{104}$ Also in 2008, a Commission working document on progress made by China in attaining the MES criteria stated that while great progress had been made in putting laws in place, implementation and enforcement was lacking. Only one of the EU's criteria, that of absence of state intervention in privatized firms and absence of barter trade, was sufficiently fulfilled. ${ }^{105}$ Again in 2010, the MES working group met with Chinese officials to discuss working on access by European consultants to the accounting information of Chinese firms. ${ }^{106}$ The Commission says it will "press China

\footnotetext{
${ }^{101}$ Li Jinshan, "Market Economy Status," 175; Freeman, Duncan, Interview with Julie Pickering, May 2012, Brussels 102،"China- Market economy status in trade defence investigations."

${ }^{103}$ Document Accompanying COM(2006) 631 final, 12

${ }^{104}$ Progress by the People's Republic of China towards graduation to market economy status, 4 ${ }^{105}$ Ibid

${ }^{106}$ Working document, Accompanying $29^{\text {th }}$ Report from the Commission, 17
} 
for improved transparency in its subsidy regimes and will insist that China abide by its WTO commitment to end the granting of prohibited subsidies."107

Many Europeans agree that while the Chinese economy is becoming more and more marketized, it is still not to be considered a full-fledged market economy. ${ }^{108}$ Others argue that the Chinese government's involvement in the economy has even increased since its accession to the WTO. ${ }^{109}$ Article 15 of China's WTO Accession Protocol states that the granting of such status is to be decided by the importing WTO country, which allows the EU to determine by which course of action it will investigate allegations of dumping and follow suit. ${ }^{110}$ This article will automatically expire in 2016 , though the legal situation after that remains somewhat unclear. ${ }^{111}$

The lack of internationally recognized accounting standards is another area recognized as a weakness in the Chinese economy. ${ }^{112}$ Due to perceived inadequate accounting standards, the EU does not think it can trust the accounts of Chinese firms, were they to be handed over for an investigation into allegations of dumping. ${ }^{113}$ The amount of government influence in the economy is perhaps the most widespread concern, which includes export credits and export financing provided by the Chinese government,

\footnotetext{
${ }^{107}$ Document Accompanying COM(2006) 631 final, 11

${ }^{108}$ Plasschaert, Sylvain. "Is China Already a Market Economy?" Presentation at the Fondation Madariaga Conference, Is China Already a Market Economy? What Implications for the EU's Trade Defence Policy? 22 June 2012, accessed on February 8 2013, http://www.madariaga.org/events/past-events-2012/713-ischina-already-a-marketeconomy-what-implications-for-the-eu-trade-defence-policy

${ }^{109}$ Fox and Godement, A Power Audit of EU-China Relations, 11

${ }^{110}$ Protocol on the Accession of the People's Republic of China, accessed on February 82013 , http:/unpan1.un.org/intradoc/groups/public/documents/APCITY/UNPAN002123.pdf

III Inès Van Lierde, "China: MES? The concerns of the EU Industry," presentation at the Fondation Madariaga Conference, Is China Already a Market Economy? What Implications for the EU's Trade Defence Policy? 22 June 2012, accessed on February 8 2013. http://www.madariaga.org/events/pastevents-2012/713-is-china-already-a-marketeconomy-what-implications-for-the-eu-trade-defence-policy

112 European Union, "China- Market economy status in trade defence investigations," 28 June 2004, Memo/04/163. Accessed on February 8, 2013, http://europa.eu/rapid/press-release MEMO-04163 en.htm?locale $=$ en

${ }^{113}$ Klenner, "Economic Relations between the EU and China," 344
} 
and of course, the high degree of state-owned enterprises and favoured industries, which have access to cheap credit on a non-commercial basis, as well as tax discrimination. ${ }^{114}$ The Chinese government also continues price-setting in certain sectors, namely the energy sector, which is thought to have a profound impact on the cost of secondary goods. ${ }^{115}$ Due to these perceived problems in the Chinese economy, the thinking is that European firms cannot adequately compete with cheap Chinese imports sold below-cost. European firms or member states (on behalf of its firms) affected can apply for an antidumping investigation, which is conducted by DG Trade of the Commission. ${ }^{116}$

Although the EU has outlined a set of problems still existing within the Chinese economy, China's accession to the WTO signaled its tacit approval and adoption of certain international market norms. Throughout the fifteen years of formal negotiation for WTO accession, the Chinese increasingly adapted to the system of international trade, and have in fact proven to be willing to 'play by the rules.' The EU strongly supported China's accession to the WTO, and along with the US, played a significant role in showing China 'the ropes' during the accession process. ${ }^{117}$ The European Commission even led China through a tough negotiation process prior to signing the EU's agreement on Chinese accession, which included receiving input from lobby groups and key sectors that might be affected, including automobiles and telecommunications. ${ }^{118}$ Some

\footnotetext{
114 "Fact sheet on trade relations."

${ }^{115}$ Progress by the People's Republic of China towards graduation to market economy status, 4

${ }^{116}$ If the results of the investigation determine that dumping has taken place, material injury has been caused and that there is a causal link between the dumping and the injury, the Directorate of Trade Defence makes recommendations to the Anti-Dumping Advisory Committee, which votes according to qualified majority. This last process will determine the course of action, which may involve a five-year imposition of export duties or an agreement by the exporting industry to begin selling at an acceptable price indicating it is no longer dumping.

${ }^{117}$ Klenner, "Economic Relations between the EU and China," 341; Holslag, "The Elusive Axis," 307

${ }^{118}$ Defraigne, "The World Trade Organization," 159
} 
commentators have expressed their surprise at the fact that despite appearing more proChinese (in the WTO) than the US ever was, the Commission was more stringent in the negotiation process. ${ }^{119}$

China's agreement with the WTO, outlined in the Protocol of Accession, is rather unique, containing both the standard rules of accession as well as additional obligations specific to China, called 'WTO-plus'. These impact China's ability to seek Special and Differential Treatment as most developing member states can, and are quite stringent as to the defence measures other states can use. ${ }^{120}$ The measures put in place for Chinese accession during the negotiation process have been called particularly stringent, in which 700 binding commitments were made. ${ }^{121}$

The Chinese criticize the EU's position on MES, notably by claiming that it is done for protectionist reasons. ${ }^{122}$ Beijing perceives it as a great injustice and as discriminatory, despite the fact that it agreed to be considered an economy in transition, as well as to Article 15 of its accession protocol (which allows WTO members states to determine how they judge its economy for trade defence cases), in 2001 when it signed this agreement. ${ }^{123}$ Beijing also makes frequent references to the latter's granting of MES to Russia, which the Chinese view as having less of a market economy. ${ }^{124}$ However, DG

\footnotetext{
${ }^{119}$ Klenner, "Economic Relations between the EU and China," 342

${ }^{120}$ For example, they can use 'WTO-minus' measures, which broaden the scope for using trade defence measures than what would typically be allowed under the WTO. Julia Ya Qin, "“'WTO-Plus" Obligations and Their Implications for the World Trade Organization Legal System: An Appraisal of the China Accession Protocol," Journal of World Trade, 37:3 (2003): 483-484; European Parliament. EU-China Trade Relations. Study. July 2011. EXPO/B/INTA/ FWC 2009-01/Lot7-14, 8. Accessed January 2013. http://www.europarl.europa.eu/committees/en/studiesdownload.html?languageDocument=EN\&file $=48592$ ${ }^{121}$ Defraigne, "The World Trade Organization," 159

122 "Commentary: Time for EU to recognize China's market economy status," Xinhua English News, accessed February 8 2012, http://news.xinhuanet.com/english2010/indepth/2011-09/14/c_131138759.htm; Li Jinshan, "Market Economy Status," 172

${ }^{123}$ Klenner, "Economic Relations between the EU and China," 343

${ }^{124}$ Li Jinshan, "Market Economy Status," 176
} 
Trade has been transparent in justifying its decision, based on the five criteria it imposes. The five criteria were applied to Russia before it was granted MES in 2002; the EU's position then was that "Russia has made great progress since the last review which was conducted in 2000. This progress justifies an adjustment of the current system." 125 For China, this is symbolic politics, given that the status actually has little bearing on EU-China trade. Only about $1 \%$ of the bilateral trade is affected by trade defence measures, and within those measures taken, some industries would be considered to be operating under market conditions. ${ }^{126}$ As well, conditions have been put in place by the Commission to deal with specific cases that may not be found in violation. Chinese companies found to be working according to market conditions will be granted MarketEconomy Treatment (MET), despite being based in a non-MES country. ${ }^{127}$ China is identified by DG Trade's Trade Defence Directorate as belonging to the group of countries to which these exceptions apply, which may nullify the capacity of the EU to systematically reference the status of the entire Chinese economy to block imports. Just as importantly, the Chinese have also increased their use of anti-dumping against the EU, and have even been found by the WTO to be violating WTO commitments through its imposition of illegal trade defence measures against X-ray scanners exported by the EU,

\footnotetext{
${ }^{125}$ European Commission, Press Release, "EU announces formal recognition of Russia as "Market Economy" in major milestone on road to WTO membership," IP/02/775, May 29, 2002, accessed 16 February 2013, http://europa.eu/rapid/press-release IP-02-775 en.htm 126 "Commentary: Time for EU to recognize China's market economy status." ${ }^{127}$ DG Trade's website explains to community industries that "exporters from economies in transition may also receive specific claim forms which they can fill in to show that they are operating under market economy principles or to claim their own individual duty rate. "Anti-dumping: Investigations," European Commission, Trade, accessed February 9, 2013, http://ec.europa.eu/trade/tackling-unfair-trade/tradedefence/anti-dumping/investigations/\#footnote-1; Van Lierde, "China: MES? The concerns of the EU Industry,"
} 
revealing China's willingness to engage in the same behavior they criticize the EU for and that the status is more symbolic than substantive. ${ }^{128}$

The claim of protectionism, beyond its use to simply protect from dumping, may have some truth to it. Some commentators have argued that the EU engages in trade defence measures to protect 'old' manufacturing industries that are, in any event, no longer that important to the EU's economy given the fragmentation of the global production of goods. ${ }^{129}$ It is possible that some actors within the EU are acting primarily to protect their own industries, and they are using the cover of trade technicalities to oppose a policy shift that could potential harm European industries by reducing margins for trade defence measures. Certain industries, such as steel, operate along market lines in Europe, and believe that they cannot compete with a Chinese steel industry, the world's top exporter, is heavily subsidized by the government, evidence for some that China is still in economic transition, rather than already a market economy. ${ }^{130}$ Recent investigations into coated steel from China, which the Commission concluded in January 2013 is a case of state-supported and deliberate dumping by the Chinese government, were initiated by Eurofer, a Brussels-based steel industry association. ${ }^{131}$ It is possible that this is a protectionist measure for large European steel manufacturers such as ArcetorMittal and ThyssenKnupp, firms with a strong lobbying presence in Brussels,

\footnotetext{
${ }^{128}$ European Commission, Press Release, "WTO confirms China illegally imposed anti-dumping duties on scanners from the EU," IP/13/164, February 26, 2013, accessed March 1, 2013, http://europa.eu/rapid/press-release IP-13-164 en.htm; Klenner, "Economic Relations between the EU and China," 344

${ }^{129}$ Fredrik Erixon, Patrick Messerlin and Razeen Sally, "China's Trade Policy Post-WTO Accession: Focus on China-EU," European Center for International Political Economy (ECIPE), http://www.ecipe.org/media/external publication pdfs/CHINAS\%20TRADE\%20POLICY\%20POSTWTO $\% 20$ ACCESSION.\%20FOCUS\%200N\%20CHINA-EU\%20RELATIONS.pdf

${ }^{130}$ Fox and Godement, $A$ Power Audit of EU-China Relations, 50

${ }^{131}$ Chaffin, "EU berates China on steel subsidies."
} 
who have seen massive layoffs and poor performance due to the economic crisis and cannot keep up with low Chinese costs. However, this industry, and others, view the use of trade defence tools as necessary for its protection against a country which even the Commission now agrees is actively working to manipulate costs of exports, and there is no direct evidence that it is acting outside of WTO-permissible laws. Rather, antidumping is for the EU a tool to "ensure fair conditions of trade between China and the EU."132 Furthermore, EU institutions do adhere to strict legal standards in line with the WTO. For example, in cases where EU and WTO laws contradict, the Commission's position is that the EU "must, so far as possible, be interpreted in a manner that is consistent with international law, in particular where provisions concerned are intended to give effect to an international agreement concluded by the union."133

There is also possibly room for bias in the process of establishing whether China can be considered a full-fledged market economy, given that DG Trade, in making its initial investigation, is able to select which country it wants to use as an 'analogue market.' This is difficult largely because China is known for the particularly cheap costs of production and labour, as well as government subsidies or other trade-distorting practices. ${ }^{134}$ This is not found to the same extent in other markets that are being used instead, which would naturally make the cost of production seem higher, and presents an opportunity to choose a country with higher costs. ${ }^{135}$ Still, this does not change the fact that the matter is technical, and the EU has acted fairly transparently in sharing with its Chinese counterparts the areas that need improving in order to satisfy the requirements.

\footnotetext{
${ }^{132}$ Document Accompanying $\operatorname{COM}(2006) 631$ final, 12

${ }^{133}$ Op. cit., 34

${ }^{134}$ Fox and Godement, $A$ Power Audit of EU-China Relations, 34

${ }^{135}$ Li Jinshan, "Market Economy Status," 176
} 
The selection of the analogue market must, according to the EU, "be explained in detail in the regulation" and "enable the parties to exercise effectively their rights."

Narratives:

What does this do to the EU's narrative of the strategic partnership? The official EU policy is also one of increasingly wanting to use the WTO structure to advance global trade. ${ }^{137}$ The EU would like to see a China fully brought into WTO system, which essentially locks in into a specific economic system and economic path.

For the EU, the non-granting of MES to China is first and foremost a technical matter, in that many of the criteria leave relatively little space for subjectivity and are discussed in detail in conjunction with Chinese officials in working group formats, (though some analysts have argued that they are far too broad). ${ }^{138}$ The criterion of equality in the strategic partnership seems to apply here, as the EU is treating China the same as other actors, despite possibility for some protectionism by European economic actors. The Chinese are aware of the limited impact MES would have on its trade with the EU in real terms, and place a great deal of importance on this status for symbolic reasons instead, as shown prior, but rather the status is about being recognized as an equal partner, and as a responsible stakeholder in global trade. Beijing explains that the appeal "for the EU to recognize China's market economy status is only being done to remind the bloc to treat China fairly." 139 Wen Jiabao said in 2011 that "based on the WTO rules, China's full market economy status will be recognized by 2016. If EU

\footnotetext{
${ }^{136}$ Working document, Accompanying $29^{\text {th }}$ Report from the Commission, 21

${ }^{137}$ Klenner, "Economic Relations between the EU and China," 341

${ }^{138}$ Erixon, Messerlin and Razeen, "China's Trade Policy."

139 "EU urged to grant China market economy status," China Daily, June 18, 2011, accessed February 8, 2013, http://www.chinadaily.com.cn/bizchina/2011-06/18/content 12729508.htm.
} 
nations can demonstrate their sincerity several years earlier, it would reflect our friendship." 140 On the EU side, the use of anti-dumping may not be symbolic at all for the EU, but rather it is a tool used against any trading partner, strategic partner or not. The EU simply does not see the use of anti-dumping measures, or most trade defence measures used correctly against Chinese companies as incongruent with the general trend of global trade liberalization. Some have argued that the EU should grant MES status in exchange for certain commitments by the Chinese to reform their economy further along the lines of its WTO commitment or market access for European firms, though this action would, however, seriously problematize the apolitical nature of the criteria. ${ }^{141}$

In terms of convergence and complementarity of interests, the EU clearly sees this as beneficial to China, though this is not clear to the latter. The criteria of mutual understanding and common vision is also lost, as one side understands the issue in a very technical, legal fashion, while for the other, it is symbolic and an injury to the claim of a friendship or partnership. This last point is really the cause of the Chinese grievances on this policy issue. The case illuminates the ways in which the strategic partnership is viewed by both actors.

Possibly the EU is also revealing the limits of its strategic actorness; it may have not granted MES to China because of global trends on this matter, particularly because it

\footnotetext{
140 "Premier Wen says China willing to help debt-ridden Europe," Xinhua English News, September 14, 2011, accessed February 10, 2013, http://news.xinhuanet.com/english2010/china/201109/14/c 131138103.htm

${ }^{141}$ Antoine Sautenet, "L'Europe et la Chine: une coopération aux dimensions juridiques complexes," Asie Visions, 3 (February 2008): 40, accessed in February 2013, http://www.ifri.org/files/centre asie/AsieVisions3 Sautenet mars08.pdf
} 
may face pressure from the US. ${ }^{142}$ Yet it is unclear why the EU would be acting simply to follow Washington's lead on this issue, which would not have any profound effect on trade with the United States.

What does this do to the EU's narrative of normative actorness? A strong case can be made that on this policy issue, the $\mathrm{EU}$ is willing to stand its normative ground despite possible backlash from Beijing and possible economic costs, given the view by some in Brussels that status would be exchanged for loans during the crisis. ${ }^{143}$ The use of codified criteria make it somewhat normative: the EU uses them as preconditions for membership, and certainly expects them of the member states. This idea has floated around and was suggested indirectly by Wen Jiabao during the 2011 World Economic Forum in Dalian, China. After stating his support for Europe's recovery, he stated that "China is willing to invest more in European countries," but implored EU leaders to "take bold steps and view relations with China with strategic vision" by recognizing China as a market economy. ${ }^{144}$

While many commentators criticize the EU's willingness and ability to act normatively in its relations with China, in this case, one can see the EU acting normatively about economic values. This may be seen as the normative narrative about the EU as an economic normative actor being actualized. The criteria set out by Brussels, despite being so technical, can qualify as norms because they are universalistic, and the EU applies them to its own members, potential members, and foreign countries alike.

\footnotetext{
142 "Is China Already a Market Economy? What Implications for the EU's Trade Defence Policy?" Conference Report, Fondation Madariaga Conference, June 22 2012, accessed on February 82013. http://www.madariaga.org/images/madariagareports/2012-jun-22\%20$\% 20$ china $\% 20$ market $\% 20$ economy\%20status.pdf

${ }_{143}$ Anonymous, Interview with Julie Pickering, May 2012, Brussels

${ }^{144}$ World Economic Forum, "Premier Wen."
} 
For the EU, bankruptcy protection and international accounting standards are benchmarks of an economic model which is advanced, and there can be no manipulations for political gains. If we accept that the criteria set forth operate as economic norms, does this, by extension, mean the EU is acting normatively on the non-granting of MES to China? Not necessarily, since there are possibly other reasons, aforementioned, why the $\mathrm{EU}$ is withholding this. Yet there is something normative about the EU's actions here, related to the EU's deep interconnectedness with the WTO system. It adheres to the values it views as being central to the very existence and operation of the WTO. While many in China, including the public, view the actions of the Europeans on this issue to be politically-motivated, the EU stands by its position that the matter is a purely technical one, which suggests something more akin to adherence to certain norms about how the global trading structure and market systems should operate. ${ }^{145}$ The EU is trying to get China, as a WTO member, to adhere to its own market rules and norms, and therefore acting normatively in defense of the technical criteria. For the EU, there is a deeply held belief in the centrality of the WTO in global trade affairs, despite the recent proliferation of bilateral arrangements. China is a relative latecomer to the WTO, and though it has benefited substantially in the last decade, it still has much to learn and implement to become a fully compliant member. In a 2010 Commission document on trade defence measures, it was explained that "during the last GATT round (the Uruguay Round), which led to the creation of the WTO and the detailed Anti-dumping and Anti-Subsidy Agreements, much of the attention was focused on the procedural and material conditions to be fulfilled before measures can be adopted. The EU played an active role in the

\footnotetext{
${ }^{145}$ Li Jinshan, "Market Economy Status," 175
} 
negotiation of these relevant criteria which are reflected in its own legislation." "146 The EU not only views its own criteria as similar to and in the spirit of the WTO, it actually played an active role in shaping them. As a result, it is possible to argue that the EU's decision on MES with China is about more than simply bilateral relations; it is about defending the WTO system. While the EU's projection of norms at the WTO is seen in its support for 'Singapore issues' and calls for a deep trade agenda, increasingly, as is the trend worldwide, the EU has had to press these issues bilaterally. ${ }^{147}$ The case of MES can be seen as a way for the EU to project and protect its market norms in direct bilateral relations with China, given their strategic partnership arrangement and the fact that multilateral trade negotiations are stalled.

In the case of the MES, this is a clear moment where it is not exactly possible to distinguish between norms and interests, although the case has been made that the EU treats granting of MES partly as a normative issue. In this case, one sees that the EU both discursively promotes the normative narrative and also has some normative actorness, and actions are generated based on this narrative, in the sense that the EU is actively reviewing China's case according to specific norms. It even looks as though this is effectively leading to changes in China, i.e. the EU has some normative power. This is because the EU has leverage in the form of the threat of antidumping measures. It is also a symbolic issue for Beijing, meaning that it may work harder to implement internationally accepted changes.

However, the EU's application of a normative narrative is again somewhat limited by its own deep trade-distorting behavior, seen notably in the CAP. Yet this does not by

\footnotetext{
${ }^{146}$ Working document, Accompanying $29^{\text {th }}$ Report from the Commission, 6

${ }^{147}$ Laïdi, "Les conséquences inattendues de la puissance européenne," 9
} 
itself nullify the EU's viewing these criteria as necessary to move international trade in a direction it wants. There is also no present evidence indicating that the EU has granted MES status for political reasons, including to Russia.

\subsection{Cooperation on Africa}

China is increasingly playing an important role in Africa, investing in a variety of sectors and investing opportunities for the exploitation of natural resources, particularly oil, natural gas and commodities (copper, uranium, zinc, platinum). ${ }^{148}$ African states are obliging the Chinese, opening their markets to them in exchange for non-conditional loans or infrastructure. The Europeans, on the other hand, have traditionally viewed Africa as an area in which they play a leading role. ${ }^{149}$ This is the case largely for historical reasons, relative geographical proximity and the fact that the EU is the largest single donor of official development assistance (ODA) to Africa, with over half of its ODA going to Africa, much of it to former European colonies. ${ }^{150}$ The EU has used political conditionality as part of its development assistance, as reaffirmed by the 2000 Cotonou Agreement, which connected trade to specific norms such as good governance and human rights. ${ }^{151}$ An unofficial competition has emerged between the two actors in

\footnotetext{
${ }^{148}$ James Kynge, “Africa, EU perspective," in China-EU, A Common Future, Eds. Stanley Crossick and Etienne Reuter. (Singapore: World Scientific Publishing Co., 2007): 145; Tanguy Struye de Swiedelande, "Offensive chinoise en Afrique," Note d'Analyse 3, Programme "Union européenne - Chine, " Chaire InBev Baillet-Latour (Avril 2009): 15, accessed February 2013, http://www.uclouvain.be/cps/ucl/doc/pols/documents/NA3-INBEV-FULL.pdf

${ }^{149}$ Liu Lirong, "The EU and China's engagement in Africa: the dilemma of socialization," Institute for Security Studies Occasional Paper, 93 (July 2011): 6, accessed February 2013, .http://www.iss.europa.eu/uploads/media/The EU and Chinas engagement in Africa.pdf ${ }^{150}$ Hayley Herman and Martyn Davies, "The EU and China: Prospects for Partnerships in Democracy Building in Africa," International Institute for Democracy and Electoral Assistance (2009): 4; Wissenbach, "The EU's response to China's Africa safari," 663-664

${ }^{151}$ Haydon, "Human rights and the development of EU-China relations," 10
} 
Africa, attributable to a number of 'hard' factors, such as geopolitical and economic interests, but also political norms and ideas. ${ }^{152}$ It has been argued that this area in EUChina relations illustrates better than any other "the clash between Chinese and European foreign policy." 153

The EU has an official 'continental' strategy with Africa and has held EU-Africa Summits in 2000 and 2007. The 2007 Lisbon Summit played a role in solidifying the EUAfrica partnership, identifying common goals and multi-level engagement and highlighting cooperation on human rights, trade, climate change, migration, and peace and security. ${ }^{154}$ Along with the EU, many of the member states have extensive relationships with African states and are experienced actors with regards to their work on the continent, where they often have well-developed networks in civil society, government and business. Partly as a result of its perceived privileged and experienced role in Africa, the Western world and the EU more specifically have reacted quite strongly to China's presence in Africa and grown alarmed by Beijing's offensive and 'conquest. ${ }^{155}$ Europeans accuse the Chinese of exploitation and of harming Africa's security by, among other things, selling arms to violent regimes and maintaining relationships with certain African dictatorships, including Zimbabwe, the Democratic Republic of the Congo, Sudan and Angola. ${ }^{156}$ In 2008, the European Parliament published a report on China's Policy and its effects on Africa, in which it criticized the

\footnotetext{
${ }^{152}$ Anna Katharina Stahl, "Trilateral Development Cooperation between the European Union, China and Africa: What Prospects for South Africa?" Stellenbosch Discussion Paper 4 (August 2012): 10

${ }^{153}$ Fox and Godement, A Power Audit of EU-China Relations, 9

${ }^{154}$ Herman and Davies, "The EU and China," 5

${ }^{155}$ Daniel Fiott, "The European Union and China in Africa: The Case of Kenya," Madariaga Paper, 3:5 (Jul 2010): 1; Struye de Swiedelande, "Offensive chinoise en Afrique," 15

${ }^{156}$ Richard Aidoo, "China's 'Image' Problem in Africa," The Diplomat, October 25, 2012, accessed January 2013. http://thediplomat.com/2012/10/25/non-interference-a-double-edged-sword-for-china-inafrica/2/; Chan, "Images, visibility and the prospects," 142
} 
effects of Chinese policies on security, aid effectiveness, human rights and good governance, and the environment, among other things, which it viewed as harmful to the efforts of European actors. ${ }^{157}$ Criticism has been voiced in the member states also: both the British and German Ministers of International Development warned of the negative effects of Chinese unconditional aid. ${ }^{158}$

Despite some criticism of China's presence in Africa, the EU, within the context of its growing strategic partnership with China, has responded by proposing cooperation, engagement and joint efforts on Africa. Former DG of Development Louis Michel, as well as Javier Solana, expressed respectively in 2006 and 2007 that engaging China constructively would be much more fruitful than voicing criticism. ${ }^{159}$ At the $2006 \mathrm{EU}$ China Summit, the leaders from both sides "stressed the importance of their relations with Africa, and stated their commitment to work together on behalf of Africa's peace, stability and sustainable development... the leaders agreed to pursue a dialogue about Africa and explore avenues for practical cooperation on the ground..."160 Specifically, the EU has initiated a framework for a dialogue between itself, China and Africa, formalized in 2008 when the European Commission proposed the creation of a trilateral dialogue and cooperation mechanism to the Chinese and African partners, expounded in a policy document entitled The EU, Africa and China: Towards a trilateral dialogue and

\footnotetext{
${ }^{157}$ European Parliament. European Parliament resolution of 23 April 2008 on China's policy and its effects on Africa. 2007/2255(INI). Accessed February 2013.

http://www.europarl.europa.eu/meetdocs/2004_2009/documents/dv/d-cn20080602_09/DCN20080602_09en.pdf

${ }_{158}$ Veronika Tywuschik, "L'UE, la Chine et l'Afrique: Un partenariat triangulaire en théorie, à deux en pratique?" European Centre for Development Policy Management (ECDPM), Editorial, EU-Africa E-Alert No. 9. (2007) accessed March 2013.

http://www.ecdpm.org/Web_ECDPM/Web/Content/Download.nsf/0/4144DD25BC450BD6C12573320044 93B9/SFILE/L\%E2\%80\%99UE,\%201a\%20Chine $\% 20$ et\%201\%E2\%80\%99Afrique.pdf

${ }^{159} \mathrm{Ibid}$

160 "Ninth EU-China Summit," 4
} 
cooperation on Africa's peace, stability and sustainability. ${ }^{161}$ The document laid out the strategy as one addressing "common challenges, common interests and concrete sectorbased partnerships" through which "synergies and mutual benefits can be maximized."162 Pragmatically, a dialogue would be created to help maintain peace and security in the continent, as well as assist in achieving the Millennium Development Goals, and work towards promoting human rights and democratic governance. ${ }^{163}$ Today, it falls within first pillar, the political pillar, of the EU-China strategic partnership. The strategy also promoted country-level meetings between Chinese ambassadors and EU delegations, as well as making Africa a "regular item on the agenda for EU-China consultations." 164 The document proposed a "shared approach" between the EU and China activities in Africa, specifically focused on "effective aid." 165 Also in 2008, a General Affairs meeting by the Council reiterated the need to engage China on its presence on the continent, concluding a number of points, including using this dialogue to "support the efforts undertaken by Africa and by the international community to promote democratisation, political and economic integration, good governance and respect for human rights." ${ }^{166}$ Both the Council and Commission recommended joint EU-China action on the following

\footnotetext{
${ }^{161}$ European Commission. The EU, Africa and China: Towards trilateral dialogue and cooperation, 17 October 2008. COM (2008)654, accessed January 2013, http://ec.europa.eu/development/icenter/repository/COMM_PDF COM_2008 0654 F COMMUNICATI ON en.pdf

${ }_{162}^{162}$ The EU, Africa and China: Towards trilateral dialogue and cooperation, 3-4

${ }^{163}$ Council of the European Union. Council Conclusions on trilateral dialogue and cooperation between the European Union, China and Africa, 2902 ${ }^{\text {nd }}$ General Affairs Council Meeting, November 10 2008: 1, accessed February 2013, http://www.consilium.europa.eu/uedocs/cmsUpload/Eu-Africa103901.pdf

${ }^{164}$ The EU, Africa and China: Towards trilateral dialogue and cooperation, 17

${ }^{165} \mathrm{Op}$. cit., 5

${ }^{166}$ Council Conclusions on trilateral dialogue and cooperation, 1
} 
initiatives: peace and security in Africa, African Infrastructure, sustainable development and natural resources, agriculture and food security. ${ }^{167}$

By most accounts, the official EU-China dialogue on Africa has not achieved anything concrete, and has possibly failed. ${ }^{168}$ There is external resistance to it by the Chinese, which Anna Katherina Stahl has said is related to two concerns voiced by the Chinese side: firstly, that African participation and support was too minimal and secondly, that Chinese participants felt there was not a genuine reciprocal dialogue, but rather a one-sided lesson by the Europeans. ${ }^{169}$ Others have argued more broadly that the Chinese are reticent to get involved in any institutionalized framework arrangement with the Europeans. ${ }^{170}$ As evidence, Stahl describes the inability of EU Commissioner Louis Michel of meeting with a Chinese counterpart in Beijing and general Chinese "indifference." ${ }^{171}$ There also seems to be a sense amongst Chinese policymakers that the normative disconnect between itself and the EU is simply too wide to have an effective dialogue. ${ }^{172}$ Furthermore, China does not seem view the EU as a serious actor in Africa. ${ }^{173}$ The Chinese are concerned about the EU's normative role in Africa, as it is explicitly highlighted in the Commission and Council documents, and are quick to accuse (along with many Africans) the EU and the West of hypocrisy and of being tainted by their

\footnotetext{
${ }^{167}$ Op. cit., 2

${ }^{168}$ Stahl, "Trilateral Development Cooperation," 16

${ }^{169}$ Op. cit., 18

${ }^{170}$ Fiott, Daniel, Interview with Julie Pickering, May 2012, Brussels

${ }^{171}$ Stahl, "Trilateral Development Cooperation," 18

${ }^{172}$ Ibid

${ }^{173}$ Holslag, "The Elusive Axis,"301; Jonathan Holslag and Sara Van Hoeymissen, Eds., "The Limits of Socialization: The search for EU-China cooperation towards security challenges in Africa,"

Brussels Institute of Contemporary China Studies, Policy Report. (May 2010): 11. Accessed March 2013. http://www.vub.ac.be/biccs/site/assets/files/apapers/Policy\%20papers/EU-China-Africa\%20(fin).pdf
} 
colonial past. ${ }^{174}$ The Chinese want to be active in Africa, but they do not necessarily agree with the EU's approach. ${ }^{175}$

China's reticence to engage the $\mathrm{EU}$ in this dialogue points to a broader clash over Chinese and European actions and norms in Africa, particularly over aid and security. ${ }^{176}$ The EU faces a situation in which its own norms, exercised in Africa for decades, come up against the norms of emerging powers like China. This disconnect is even noticeable in high-level discourse: at the 2006 EU-China Summit, the leaders shared with the press that at the summit, "the EU affirmed its attachment to the principles of good governance and human rights, as embodied in its Africa Strategy. The Chinese side emphasized the upholding of the Five Principles of Peaceful Coexistence, in particular the norms of noninterference into others' international affairs."

Beijing has demonstrated these differences in norms through its actions in Africa. In peacekeeping, for example, they have stood stalwartly by their conviction of respect for the principles of state sovereignty and non-interference, claiming that "no UN peacekeeping operations should be launched without the prior consent of the countries concerned." ${ }^{178}$ This stands in contrast to the EU, many of whose member states do not rule out interference on humanitarian grounds. ${ }^{179}$ Rather, the EU's discourse on African security revolves around the R2P and civilian security, and security has focused on the individual rather than the nation. ${ }^{180}$

\footnotetext{
${ }^{174}$ Kynge, “Africa: EU perspective," 147

${ }^{175}$ Liu, "The EU and China's engagement in Africa," 5

${ }^{176}$ Ibid

177 "Ninth EU-China Summit," 4

${ }^{178}$ Rising Star: China's New Security Diplomacy, 117

${ }^{179}$ Part of this paragraph comes from an essay written for another class

${ }^{180}$ Diez, "Constructing the Self and Changing Others," 623
} 
Africa's development is another area of contention between the two: the 'Western' approach, preferred for a long time by the EU, was one of asymmetricallyapplied conditionality in which there are rewards for good behavior, aid is usually linked to conditions and based also on 'fundamental principles. ${ }^{181}$ This approach stresses good governance, sustainable development, rule of law and a variety of other traditional norms, though in recent years the EU has moved to a more incentives-based approach. This was seen in the Lisbon Declaration of 2007, which highlighted the need for "overcoming the traditional donor-recipient relationship." 182 In contrast, the Chinese' general approach to Africa has been publicly one of strict adherence to, again, the norms of sovereignty and non-interference, in which aid and investment are given with 'no-strings-attached,' and without recognition of the official definition of Official Development Aid (ODA) used by the Organisation for Economic Co-operation and Development (OECD). ${ }^{183}$ In fact, the only conditionality for the Chinese is that African states do not recognize Taiwan diplomatically ${ }^{184}$ China sees that it could benefit significantly from having African partners on its side for support in multilateral institutions, as it acknowledged in its policy paper, saying "China will strengthen cooperation with Africa in the UN and other multilateral systems by supporting each others' just demand(s) and reasonable propositions."

\footnotetext{
${ }^{181}$ Wissenbach, "The EU's response to China's Africa safari," 666; Liu, "The EU and China's engagement in Africa," 5; Francois Bougon and Sébastien Hervieu, "Chine-Afrique: la fin de la lune de miel." Le Monde, March 23, 2013, accessed April 1, 2013, $\mathrm{http}: / / \mathrm{www}$. lemonde.fr/international/article/2013/03/22/chine-afrique-la-fin-de-la-lune-demiel_1852804_3210.html

${ }^{182}$ Herman and Davies, "The EU and China," 5

${ }^{183}$ Stahl, "Trilateral Development Cooperation," 8, 18; Herman and Davies, "The EU and China," 4

${ }^{184}$ Zhang, "Africa-China perspective," 153

${ }^{185}$ Zhang, "Africa-China perspective," 155 ; "China's African Policy."
} 
There are also increasingly questions of competition and rivalry between EU and Chinese economic actors, particularly over natural resources. In fact, part of the ESS was dedicated to the proposal of a joint EU raw materials strategy, given the dependence of the EU on imports, with China dominating the global supply. Much as the Chinese have, Europeans are increasingly looking to Africa's resource potential. Calls for a joint policy at the EU level on raw materials were answered in 2008, with the creation of a Raw Materials Initiative, which was reinforced by a policy document in 2011 . This stressed the need for market development in Africa, what Stahl has called the EU's "raw materials diplomacy," which, it is argued, was put on the EU-Africa agenda as a reaction to perceived Chinese dominance in this field. ${ }^{186}$

The presence of Chinese in Africa today, motivated by the official 'going-out policies' of the 1990s, is divided amongst economic actors with few links to the state, economic actors working for state-owned enterprises and political actors. ${ }^{187}$ Due to desires to make their presence last, and given some backlash in recent years by some African leaders, citizens and NGOs, Beijing has been, of late, on a 'charm offensive. ${ }^{188}$ Although its main imperative is economic, China depicts its involvement in Africa in political terms and discourses, and the country continues to promote its split identity as both a developing nation and a global power- as the largest developing country in the world. ${ }^{189}$ The latter is how the Chinese depict themselves in their relations with Africa,

\footnotetext{
${ }^{186}$ Stahl, Anna Katharina. "The EU Policy response to China's Resource Diplomacy in Africa." EU-China Observer, 4 (2011): 20, accessed May 2012, http://www.coleurope.eu/sites/default/files/researchpaper/eu china observer 3 2009.pdf

${ }^{87}$ Stahl, "Trilateral Development Cooperation," 8

${ }^{188}$ Holslag, "The Elusive Axis," 299

${ }^{189}$ Wissenbach, "The EU's response to China's Africa safari," 663; Geeraerts, "China, the EU, and the New Multipolarity," 61; Zhang Tiejun, "Africa- China perspective," in China-EU, A Common Future, Eds. Stanley Crossick and Etienne Reuter (Singapore: World Scientific Publishing Co., 2007): 150
} 
promoting the concept of increased 'south-south' relations, which has in fact been around since the 1960s, and win-win arrangements. ${ }^{190}$ In 2003, Wen Jiabao summarized his country's policy for Africa, saying "we do offer our assistance... without any political conditions...we will never forget the invaluable support China has received from African countries... to safeguard China's sovereignty and territorial integrity."191 A White Paper on Africa was published by Beijing in 2006, stating that "sharing similar historical experience, China and Africa have all along sympathized with and supported each other in the struggle for national liberation." ${ }^{, 192}$ China, itself until very recently recipient of aid, today provides increasing flows of aid to Africa, though it is still far behind the EU and the US. ${ }^{193}$ The country has also begun participating in security operations on the continent, and they have been working with their African partners on these issues through the framework provided by the Forum on China-Africa Cooperation (FOCAC), implemented in 2000 as the mechanism for dialogue between the two sides and a ChinaAfrica summit held in Beijing in 2006. ${ }^{194}$

Within Africa, there has been some good reception to their presence, given what many leaders perceive to be more immediate benefits from Chinese aid, including material deliverables, such as the recent US\$200m African Union building in Addis

\footnotetext{
${ }^{190}$ Balme, "From Hard to Soft Power, and Return," 32, Zhang, "Africa-China perspective," 153; Tywuschik,"L'UE, la Chine et l'Afrique."

${ }^{191}$ Zhang, "Africa-China perspective," 152

${ }^{192}$ Stahl, "Trilateral Development Cooperation," 8; "China's African Policy," January 2006, Ministry of Foreign Affairs of the People's Republic of China, accessed June 2012. http://www.fmprc.gov.cn/eng/zxxx/t230615.htm

${ }^{193}$ In July 2012, Beijing pledged US\$20b in aid to African states for infrastructure and agriculture over the next three years. Stahl, "Trilateral Development Cooperation," 8; Jane Perlez, "With \$20 Billion Loan Pledge, China Strengthens Its Ties to African Nations," New York Times, July 19, 2012, accessed October 2013. http://www.nytimes.com/2012/07/20/world/asia/china-pledges-20-billion-in-loans-to-africannations.html? $r=0$

194 "China's African Policy."; Tywuschik,"L'UE, la Chine et l'Afrique."
} 
Ababa. ${ }^{195}$ Benefits are gained quickly through the Chinese' goods-for-resources or loansfor-resources approach, an approach which openly derides the language of donor/recipient so synonymous with the Western aid model. ${ }^{196}$ Chad, for example, is a case in which the leadership has enjoyed the benefits of a close partnership with China, having invested heavily in oil, opening up refining on-site, and providing infrastructure, such as a rail line, a hospital and an international airport. The World Bank, on the other hand, invested in Chad with the condition that oil revenues would be used on human development projects, something President Déby did not want to have dictated to him. ${ }^{197}$ This was also demonstrated in the case of Zimbabwe, where the Chinese stepped in to offer aid and weapons-transfers to President Mugabe after the EU broke off aid in 2002 for human rights violations. ${ }^{198}$ Yet there has also been some backlash by civil society and certain leaders, concerned with environmental impacts and the Chinese use of its own workers rather than the local workers, in countries like Zambia, Sudan and Angola. ${ }^{199}$ In the case of Zambia, the presence of Chinese workers in its copper belt region was a predominant theme in the 2011 election. ${ }^{200}$

However, China's actions in Africa also reveal two emerging trends of partial adaptation to Western norms, as well as deep-rooted pragmatism in their foreign policy. In terms of adaptation, China's actions represent some adoption of 'Western' norms, and the EU is seen as possibly having played a part in this. The Chinese are slowly revealing

\footnotetext{
195 "Afican Union opens Chinese-fumded HQ in Ethiopia," BBC News, January 28, 2012, accessed February 10, 2013. http://www.bbc.co.uk/news/world-africa-16770932

${ }^{196}$ Zhang, "Africa-China perspective," 155

${ }^{197}$ John Schellhase, "China's Chad Courtship," The Diplomat, June 26, 2012, accessed November 2012. http://thediplomat.com/china-power/chinas-chad-courtship/

${ }^{198}$ Tywuschik,"L'UE, la Chine et l'Afrique."

${ }^{199}$ Zhang, "Africa- China perspective," 154; Aidoo, "China's 'Image' Problem in Africa."

${ }^{200}$ Palitza, Kristin, "Why Zambia's Elections Will Be All About China," Time, September 19, 2011, accessed February 20, 2013, http:/www.time.com/time/world/article/0,8599,2093381,00.html
} 
some willingness to alter, for example, their norm of non-interference in relations with African states. ${ }^{201}$ In the case of Libya, for example, China's abstention in the vote on resolution 1973 for intervention was seen as a "green light" by Western powers, and meeting of Chinese diplomats with Libyan opposition in Qatar before Gaddafi's death are seen as modifications or creative re-workings of non-interference. ${ }^{202}$ In Sudan, as well, China may have 'compromised' its principle of non-interference by working closely behind the scenes with Sudanese partners in both the North and South to establish a deal in the summer of 2012, thus 'intervening' in their internal political affairs because they were facing extensive losses with the shutting down of oil production in South Sudan. ${ }^{203}$ Again in March 2012, China voted in favour of a United Nation Security Council (UNSC) resolution allowing for the intervention of troops in Côte d'Ivoire. ${ }^{204}$ Beijing also showcases increasingly some soft power projection in Africa, where it has gone on a 'charm offensive,' which is revealing of its desire to be seen as a responsible stakeholder, able to play the game as well as any other power, though all the while balancing its presence with respect for non-interference. ${ }^{205}$ These efforts have included granting thousands of African students scholarships to study in China and opening up Africafocused English-language edition of the China Daily in certain African countries. ${ }^{206}$

\footnotetext{
${ }^{201}$ Holslag, "The Elusive Axis," 300; This sentence was taken from an essay written for another class ${ }^{202}$ Aidoo, "China's 'Image' Problem in Africa"

${ }^{203}$ David H. Shinn, “China's Deft Sudan Diplomacy,” The Diplomat, September 19, 2012, accessed February 27, 2013, http:/thediplomat.com/china-power/chinas-deft-sudan-diplomacy/

${ }^{204}$ Vaïsse and Kundnan, "European Foreign Policy Scorecard 2012," 39; Laure Beaulieu, "En Afrique, "les groupes chinois profitent du retrait des Occidentaux," Le Monde Internationale, July 19, 2012, accessed January 2013. http://www.lemonde.fr/international/article/2012/07/19/en-afrique-les-groupes-chinoisprofitent-du-retrait-des-occidentaux 1735802 3210.html; Fiott, Daniel, Interview with Julie Pickering, May 2012, Brussels

${ }^{205}$ Holslag, "The Elusive Axis," 299, 300

${ }^{206}$ Kynge, "Africa- EU perspective," 146; Colin Shek, "Chinese media expands Africa presence," AWazeera, January 24, 2013, accessed January 24, 2013. http://www.aljazeera.com/indepth/features/2013/01/201312071929822435.html
} 
Beijing realizes it may not be able to play the non-interference and sovereignty card forever, particularly given the malleability of the concept of sovereignty in certain parts of Africa and its own desire to maintain good relations with African states. ${ }^{207}$ It is possible that the precarious security situation of some African states, which has led to the kidnapping and murder of Chinese workers in instances in Nigeria, Ethiopia and recently Sudan, may require China, at some point, to intervene, as it had to do in 2008 in Chad after rebels took the capital city and threatened Chinese nationals. ${ }^{208}$ As a result, the Chinese may be increasingly careful about falling into a 'narrative trap.'

Narratives:

The fact that the EU and China are having a dialogue about these issues suggests, officially, the logic of the strategic partnership narrative. The EU has reached out to the Chinese on the ground in Africa, seeking joint partnership on projects. ${ }^{209}$ Certainly both actors have strong complementary interests on the continent, political and economic, as is best seen in the cooperation on anti-piracy projects in the Gulf of Aden, where the EU has played a leading role. The discourse also suggests they can agree on a cooperative approach that is long-term oriented. However, any convergence between the EU and China on this policy area may be the result of other forces, and not of any intentional congruence of positions or rapprochement. ${ }^{210}$ Chief among these is China's realization of the limits of its own system, although perhaps public 'shaming' or general international scrutiny has led to changes, rather than the EU's role necessarily. Cooperation between

\footnotetext{
${ }^{207}$ Fiott, Daniel, Interview with Julie Pickering, May 2012, Brussels; Wissenbach, “The EU's response to China's Africa safari," 667-668

${ }^{208}$ Schellhase, "China's Chad Courtship,"

${ }^{209}$ Fiott, Daniel, Interview with Julie Pickering, May 2012, Brussels

${ }^{210}$ Holslag, "The Elusive Axis," 301
} 
the two is limited, as seen in the unsuccessful attempts at coordinating projects and meetings between the EU delegations and Chinese embassies in certain African countries, which puts into question the idea of a partnership of any sort. ${ }^{211}$

Another problem related to the strategic partnership narrative is that the Chinese do not seem to view the EU as an actor with any leverage on the African continent. ${ }^{212}$ Its cohesiveness as an actor is likely called into question by the divide between the EU discourse on development, and the actions by certain European economic actors and the member states, which sometimes trump the EU's talk of human rights and good governance. ${ }^{213}$ As well, the EU institutions are not in a position to cover all policy areas with regards to Africa, as many member states have well developed policies towards the continent and specific countries, and the EU is not in control of resource acquisition by its economic firms operating abroad. ${ }^{214}$ The idea of equality of partners is also questionable: some in the EU seem to view the dialogue as a one-way socialization process, through which the Chinese will learn from Europe's extensive experience in Africa. $^{215}$

In regards to the EU's normative actorness narrative, there is strong reason to believe that there exists a genuine commitment to the amelioration of conditions in Africa within the EU institutions, and certainly it is fulfilling the conditions of being normative in its discourse and many of its actions in development. In this case, and with the use of the dialogue specifically, one can see the EU attempted to engage China on a number of

\footnotetext{
${ }^{211}$ Fiott, Daniel, Interview with Julie Pickering, May 2012, Brussels

${ }^{212}$ Holslag, "The Elusive Axis," 301

${ }^{213}$ Herman and Davies, "The EU and China," 10

${ }^{214}$ Fiott, Daniel, Interview with Julie Pickering, May 2012, Brussels

${ }^{215} \mathrm{Liu}$, "The EU and China's engagement in Africa," 5; Stahl, "Trilateral Development Cooperation," 17
} 
traditional political normative issues. The creation of a dialogue with the Chinese, despite having little content, does signal an attempt to generate action based on this normative narrative. The stated objective of having delegations in African states reach out to Chinese diplomatic staff also indicate an attempt at sharing best practices and possibly teaching them.

However, the problems with implementing this narrative are multiple. While the EU acts normatively, it has very little leverage to convince the Chinese. The lack of success of the dialogue would indicate that there is strong resistance to the EU's norms by the Chinese, which would challenge any of the EU's normative power. The Chinese have demonstrated at least partial adherence to a normative code different than that of the Europeans. China emphasizes non-interference and sovereignty based on its own internal experience, and in doing so positing themselves as a normative, altruistic player, albeit of a different type than the EU. Yet there is also reason to believe that the Chinese discourse is limited, for three reasons: firstly, China's approach is foremost a pragmatic one, and not ideological. Secondly, the Chinese do not want to fall into a normative trap in a continent in which these very norms are tenuous. Lastly, China is still a relatively new foreign policy actor, and non-interference in Africa may be a result of its incapacity to be a fully influential actor in any sense other than economic. ${ }^{216}$

The EU may also be using normative discourse as justification for behavior really aimed at reinstating itself strategically and economically on the continent. It may feel threatened by Chinese resource diplomacy, as seen with the initiation of the European Raw Materials Initiative, which many view as a response to increased Chinese presence

\footnotetext{
${ }^{216}$ Wissenbach, "The EU's response to China's Africa safari,” 667
} 
on the continent. ${ }^{217}$ The maintenance of the CAP by the EU has also been shown to be to the detriment of African states dependent on trade in agriculture, opening up a broader debate about member states' adherence to development goals.

In this case, it is particularly difficult to separate norms from interests, given that the EU is likely protecting both. On the one hand, it has an interest in promoting a normative system that protects its African partners and the hard work of European development organizations and NGOs. In the face of a perceived Chinese 'scramble' for resources, the EU is genuinely committed to the principles of sustainable development and conditional aid. However, the EU's economic actors also have a strong stake in protecting its economic and geostrategic interests in Africa, and in that sense the dialogue may be viewed as a way of trying to 'keep tabs' on the Chinese.

The normative narrative case is a strong one, and goes far in explaining the EU's behavior, as it is guided by certain strongly held beliefs about linking aid and trade to certain norms. It is possible that China will increasingly look to the West to shape its behaviour in Africa, as the limits of its own model become increasingly clear. The case study may also signal the weakness of an arrangement like the strategic partnership, given that in this policy area, an attempt at engagement, in the form of a dialogue, has once again proven to be of little value. Still, the EU is using the narrative, and this is simply a case of limited leverage.

\footnotetext{
${ }^{217}$ Stahl, "Trilateral Development Cooperation," 20; Part of this paragraph was taken from an essay for a different class
} 


\section{Chapter: Conclusion}

This thesis has aimed to contribute to studies of the EU's role in international affairs. It has proposed a constructivist reading of the EU, positing that this perspective of the EU's position in the world is well-suited to analysis of its discourse, through which the EU's self-understanding of its global role can best be understood. Furthermore, a constructivist interpretation may be most appropriate to understand the narrative and discursive exercises the EU itself is engaged in, and the constructed approaches it uses in its global endeavours.

The thesis has also sought to contribute to the field of study of EU-China relations, which is expanding in the EU, but is also a nascent field within China's international relations community. Given the importance the EU places on its relations with China, analysis of specific areas of cooperation has been undertaken in an attempt to further elucidate trends in the relations. By specifically analyzing political narratives within the context of EU-China relations, it has been shown that Brussels attempts to portray itself as a serious actor vis-à-vis Beijing, using certain discourse to do so. One of the narratives it utilizes, the narrative of the strategic partnership is, from the outset, viewed as interest-based and holding little room for normative issues as they are considered in the traditional sense. This type of engagement looks like one based primarily on economic and strategic considerations, and as an explicit attempt by the EU to gain from, and stay relevant in, a changing global system. It has been indicated that the EU refers a great deal to this narrative discursively, specifically using a number of tropes, such as that of mutual benefits, interest gaining, and equality of partners. The case studies 
reveal that through its actions, the EU does in fact attempt to follow the logic of this narrative and instrumentalize it, for example by favouring constructive engagement over confrontation, and initiating dialogues and working groups on a number of policy areas thought to achieve results in the long-term and in the interest of both actors. However, due to ambiguities in the narrative, such as lack of strategy, cohesiveness or leverage, the EU is not always able to act in a way towards China that would suggest such a close partnership, or a particularly strategic one at that.

The EU also has been shown to depict itself, at least discursively, as a normative actor, both broadly and in its relations with China. Yet many commentators have argued that the EU is unable to exercise any normative power with a state like China. Some of these critiques seem to be justified, and the EU has difficulty exercising much of this power towards China. Yet the case studies examined also indicated that the EU does in fact refer to its normative identity both in its discourse and to generate actions, and so it is acting normatively in its relations and instrumentalizing this actorness to the extent that may be possible. Furthermore, because the definition of normative narrative in this piece is inclusive of economic and market norms, it was possible to argue, especially looking at the case of the MES, that the EU may in fact have some power to shape and socialize third countries like China.

Furthermore, a detailed analysis of both narratives suggests similarities between the two, both in discourse and in implementation, that make it difficult to always distinguish between the two. For the sake of this work, the two have been treated separately, but deep analysis of the discourse and the ways they are utilized suggest that they share many traits. For example, highlighting tropes and analytic features of the 
strategic partnership narrative, as well as its implementation in practice, reveals it has a normative element to it, found specifically in language on effective multilateralism and on engaging China in order to help with its 'peaceful rise,' which requires some formulation of norms and values by the EU. The case studies also made it possible to explore the possibility that perhaps the normative narrative is not completely distinguishable from interests, and that the EU may be acting normatively in the way it approaches liberal economics and market regulation. If the EU is acting normatively in this sense, the question is raised of the extent to which this kind of narrative stands in contrast to more overtly interest-based foreign overtures and foreign policies. Overall, analysis of the narratives and the case studies indicate that perhaps these two are more complementary than oppositional, and are possibly 'two sides of the same coin.'

Research conducted for this thesis revealed certain lacunae in the literature that may require further study. While study of EU-China relations are of growing interest, it is still a relatively new area, and as such, it may benefit from further studies into specialized areas/policies of these relations, or comparisons to other major EU external relations, such as Russia or India. Given the ambiguities and questions surrounding the concept of strategic partnerships, much more work could be conducted on these, either as instruments or as narratives. Due to the lack of clarity on strategic partnerships within Brussels' own discourse, research may focus more broadly on the EU's capacity to act or be strategic, as well as the various tools or mechanisms through which the EU seeks to achieve or engage strategy. Works on the EU as a normative actor have focused a great deal on ideational factors, and problems associated with the kind of power the EU may have in exercising these factors. Another set of literature has focused on the EU's role in 
regulatory affairs and in institutionalizing principles of market and economic activities. While some aforementioned authors have suggested, or even explicitly highlighted, similarities between these two bodies of scholarship and the normative element of the EU's economic activities, EU studies would benefit from exploring this link further. Such work may help illuminate exactly what kind of power the EU is or has in international affairs, as well as the extent to which it can influence other states to adopt its norms and values.

The use of discourse analysis, in the context of the conceptualization of political narratives, exists within EU studies, but does not seem to be widely applied to works on the EU's actorness in global affairs. Yet there does seem to be a great deal of value, or analytic 'gain,' in using this approach in studies of international relations. This gain comes mainly from the fact that this tool allows the researcher to bring together discursive 'moments' in an organized and cohesive manner. If a narrative can be fashioned from the wider discourse, possibilities are opened for comparing how a political actor views itself to how others view it or how it acts in practice. In addition, there seems to be increasing recognition that political actors themselves use political narratives to explicate their worldviews, based on their sense of their histories and their relative positions without the global structure. More work may be needed to identify specifically what makes a political narrative, and the ways in which rhetorical devices or discourse may constitute narration. Looking at the EU, further research on its discourse or narratives, as well as the usefulness of this kind of analytic model more broadly, would be beneficial in studies of its role in international affairs, as it would allow academics to distinguish between the EU's self-perception and actual effectiveness of implementation 
or exercising of power. Much of the current literature on the EU's global actorness focuses on the lack of power or the difficulty it faces as a serious foreign policy player. This last approach may be missing the broader idea that political actors may, in fact, gain power through self-actualization or self-referencing of specific discourse. The constructivist roots of much of discourse analysis are especially well-suited to the idea that political actors may have the capacity to imbue themselves with powers through the use of narratives and discourse that present them as efficacious, strong and cohesive, particularly if they are able to institutionalize this perception through official frameworks with other strong political actors.

Overall, the burgeoning field of study of the EU's role in global affairs has grown rapidly in recent years, and is increasingly becoming dynamic and exciting. This thesis has sought to contribute to the field by looking at specific analytic tools and focusing them on the EU's relations with a specific country. Future research may serve to answer and elucidate the questions of EU global actorness in EU studies and the field of international relations more broadly. 


\section{Chapter: Bibliography}

\section{Secondary Sources}

Aggestam, Lisbeth. "The World in Our Mind: Normative Power in a Multi-Polar World." In Normative Power Europe in a Changing World: A Discussion. Clingendael European Papers 5. Edited by André Gerrits, 25-36 (December 2009) Accessed May 2012. http://www.clingendael.nl/publications/2009/20091200_cesp_paper_gerrits.pdf

Aidoo, Richard. "China's 'Image' Problem in Africa." The Diplomat, October 25, 2012. Accessed January 2013, http://thediplomat.com/2012/10/25/non-interference-a-doubleedged-sword-for-china-in-africa/2/

Allen, David and Michael Smith. "The EU, Strategic Diplomacy and the BRIC Countries." Jean Monnet Multilateral Research Network, Policy Paper, 11 (February 2012): 1-10.

Algieri, Franco. "It's the system that matters: institutionalization and making of EU policy towards China." In China-Europe Relations: Perceptions, policies and prospects. Edited by David Shambaugh, Eberhard Sandschneider and Zhou Hong, 65-83. London: Routledge, 2008.

Ash, Robert. « Europe's commercial relations with China. " In China-Europe Relations: Perceptions, policies and prospects. Edited by David Shambaugh, Eberhard Sandschneider and Zhou Hong, 189-230. London: Routledge, 2008.

Balducci, Giuseppe. "The Limits of Normative Power Europe in Asia: The Case of Human Rights in China." East Asia, 27 (2010): 35-55.

Balducci, Giuseppe. "Inside Normative Power Europe: Actors and Processes in the European Promotion of Human Rights in China." EU Diplomacy Papers, College of Europe, 8 (2008): 1-31.

Balfour, Rosa. "EU Strategic Partnerships: are they worth the name?" European Policy Centre, Commentary. September 15, 2010. Accessed January 2013. http://www.epc.eu/documents/uploads/pub_1145_eu_strategic partnerships are they worth the name.pdf

Balme, Richard. "From Hard to Soft Power, and Return? The European Union, China and Human Rights." Governance and Globalization, Sciences Po in China. (November 2007): 1-37. Accessed May 2012. http://sciencespoglobalgovernance.net/q=webfm send/21 
Balme, Richard. "The EU, China and human rights." In EU Foreign Policy in a Globalised World: Normative Power and Social Preferences. Edited by Zaki Laïdi, 143173. New York: Routledge, 2008.

Baylis, John and Steve Smith, Eds. The Globalization of World Politics: An introduction to international relations, Third Edition. Oxford: Oxford University Press, 2006.

Beaulieu, Laure. "En Afrique, "les groupes chinois profitent du retrait des Occidentaux." Le Monde Internationale, July 19, 2012. Accessed January 2013.

http://www.lemonde.fr/international/article/2012/07/19/en-afrique-les-groupes-chinoisprofitent-du-retrait-des-occidentaux_1735802 3210.html

Berkofsky, Axel. "EU-China Relations- Really Towards a "Strategic Partnership"?" Sicherheit und Frieden, 4:3 (2006): 185-191. Accessed March 2013. http://www.sicherheit-und-frieden.nomos.de/fileadmin/suf/doc/SuF 06 04.pdf

Biscop, Sven and Thomas Renard. "EU's strategic partnerships lack content." EUObserver.com, August 27, 2009. Accessed May 2012. http://euobserver.com/opinion/28584

Bindi, Federiga and Irina Angelescu. "Introduction." In The Foreign Policy of the European Union: Assessing Europe's Role in the World. Edited by Federiga Bindi, 1-12. Washington, D.C.: Brookings Institution Press, 2010.

Börzel, Tanja A. and Thomas Risse. "The Transformative Power of Europe: The European Union and the Diffusion of Ideas." KFG Working Paper Series, 1 (May 2009). Accessed March 2013. http://userpage.fuberlin.de/kfgeu/kfgwp/wpseries/WorkingPaperKFG_1.pdf

Cabestan, Jean-Pierre. "The Role of France in Sino-European Relations: Central or Marginal." In The International Politics of EU-China Relations. Edited by David Kerr and Liu Fei, 129-150. Oxford: Oxford University Press, 2007.

Cabestan, Jean-Pierre. "Learning from the EU?" China's changing outlook towards multilateralism." In China and the New International Order. Edited by Wang Gungwu and Zheng Yongnian, 203-217. New York: Routledge, 2008.

Cairi, Mara. "The EU-China Relationship: From Cooperation to Strategic Partnership." In The Foreign Policy of the European Union: Assessing Europe's Role in the World. Edited by Federiga Bindi, 263-272. Washington, D.C.: Brookings Institution Press, 2010.

Casarini, Nicola. "China's Approach to US debt and the Eurozone crisis." China's Geoeconomic Strategy, LSE IDEAS, 43-47. Accessed February 15, 2013. http://www2.lse.ac.uk/IDEAS/publications/reports/pdf/SR012/casarini.pdf 
Chan, Kenneth. "Images, visibility and the prospects of soft power of the EU in Asia: the case of China." Asia Europe Journal, 8 (2010): 133-147.

Checkel, Jeffrey T. "International Norms and Domestic Politics: Bridging the RationalistConstructivist Divide." European Journal of International Relations, 3:4 (1997): 473-495

Checkel, Jeffrey T. "The Constructivist Turn in International Relations Theory." World Politics, 5:2 (1998): 324-348

Checkel, Jeffrey T. "Social construction and integration." Journal of European Public Policy, 6:4 (1999): 545-560. Accessed February 2013.

http://graduateinstitute.ch/webdav/site/political_science/shared/political science/7183/4t h\%20week/Checkel.pdf

Checkel, Jeffrey T. "International Institutions and Socialization." ARENA Working Paper (April 1999). Accessed March 2013. http://www.sv.uio.no/arena/english/research/publications/arenapublications/workingpapers/working-papers 1999/wp99 5.htm

Ching, Frank. "Changing Dynamics in EU-China Arms Relations." China Brief, 4:5. (2004) Accessed March 2013. http://www.jamestown.org/single/?no cache $=1 \&$ tx ttnews $\% 5 \mathrm{Btt}$ news $\% 5 \mathrm{D}=3631$

Coelmont, Jo. "An EU Security Strategy: An Attractive Narrative." Egmont Security Policy Brief, 34. (March 2012): 1-5.

Dai, Bingran. "Promoting Mutual Understanding- China perspective." In China-EU, A Common Future. Edited by Stanley Crossick and Etienne Reuter, 249-263. Singapore: World Scientific Publishing Co., 2007.

Damro, Chad. "Market power Europe." Mercury, E-Paper, 5 (October 2010): 1-22. Accessed January 2013. http://mercury.uni-koeln.de/fileadmin/user upload/Epaper no5 r2010.pdf

Defraigne, Pierre. "Pourquoi la Chine veut une Europe forte?" Madariaga Paper, 5:2 (September 2012) Accessed January 2013. http://www.madariaga.org/publications/madariaga-papers/748-pourquoi-la-chine-veutune-europe-forte

Defraigne, Pierre. "The World Trade Organization." In China-EU, A Common Future. Edited by Stanley Crossick and Etienne Reuter, 159-169. Singapore: World Scientific Publishing Co., 2007.

Ebels, Philip. "EU sees dramatic surge in investment from China." EUObserver.com, July 6, 2010. Accessed on February 15, 2013. http://euobserver.com/china/116537 
"Enter the Dragon: A successful case study of Chinese investment in Poland" Deloitte/Invest in Poland, case study. November 15, 2012. Accessed on February 82013. http://www.deloittelegalce.com/en/content/enter-dragon-successful-case-study-chineseinvestment-poland

Erixon, Fredrik, Patrick Messerlin and Razeen Sally. "China's Trade Policy Post-WTO Accession: Focus on China-EU." European Center for International Political Economy (ECIPE).

http://www.ecipe.org/media/external publication pdfs/CHINAS\%20TRADE\%20POLIC Y\%20POST-WTO\%20ACCESSION.\%20FOCUS\%200N\%20CHINAEU\%20RELATIONS.pdf

Diez, Thomas. "Constructing the Self and Changing Others: Reconsidering 'Normative Power Europe." Millennium: Journal of International Studies, 33:3 (2005): 613-636.

Ding, Yifan. "The World Trade Organization- China perspective." In China-EU, A Common Future. Edited by Stanley Crossick and Etienne Reuter, 167-169. Singapore: World Scientific Publishing Co., 2007.

Faber Van Der Meulen, Evert. "Gas Supply and EU-Russia Relations." Europe-Asia Studies, 61:5 (July 2009): 833-856.

Falker, Robert. "The political economy of 'normative power' Europe: EU environmental leadership in international biotechnology regulation." Journal of European Public Policy, 14: 4 (2007): 507-526.

Fiott, Daniel. "The European Union's Normative Power in a Multipolar World." Paper presented at the EUSA Biennial Conference 2011, Boston, United States, March 3-5 2011. 1-13.

Fiott, Daniel. "The European Union and China in Africa: The Case of Kenya." Madariaga Paper, 3:5 (Jul 2010): 1-11.

Forchtner, Bernhard and Christoffer Kølvraa. "Narrating a 'new Europe"': From "bitter past' to self-righteousness?" Discourse \& Society, 23:4 (2012): 377-400.

Foot, Rosemary. "Strategy, politics, and world order perspective: comparing the EU and US approaches to China's resurgence." In US-China-EU Relations: Managing the new world order. Edited by Robert Ross, Øystein Tunsjø and Zhang Tuosheng, 212-234. London: Routledge, 2010.

Fox, John, and Francois Godement, eds. A Power Audit of EU-China Relations, European Council of Foreign Relations Policy Report. 17 April 2009. Accessed in May 2013. http://ecfr.eu/page/-/ECFR12__A POWER AUDIT OF EU-

CHINA RELATIONS.pdf 
Geeraerts, Gustaaf. "China, the EU, and the New Multipolarity." European Review, 19:1 (2011): 57-67.

Gerrits, André. "Normative Power Europe: Introductory Observations on a Controversial Nortion." In Normative Power Europe in a Changing World: A Discussion. Clingendael European Papers 5. Edited by André Gerrits, 1-8 (December 2009) Accessed May 2012. http://www.clingendael.nl/publications/2009/20091200 cesp_paper_gerrits.pdf

Gill, Bates. "China's Evolving Appraoch to Multilateralism and Global Governance: Implications for the European Union." In The Role of the European Union in Asia: China and India as Strategic Partners. Edited by Bart Gaens, Juha Jokela and Eija Limnell, 139-154. Surrey: Ashgate Publishing, 2009.

Gill, Bates. Rising Star: China's New Security Diplomacy. Washington D.C.: The Brookings Institute, 2007.

Gill, Bates and Melissa Murphy. China-Europe Relations: Implications and Policy Responses for the United States. Washington, D.C.: The Center for Strategic and International Studies Press, 2008.

Gratius, Susanne. "The EU and the 'special ten': deepening or widening Strategic Partnerships?" FRIDE Policy Brief, 76 (June 2011): 1-5. Accessed January 2013. http://www.jamestown.org/single/?no cache $=1 \&$ tx ttnews $\% 5$ Btt_news $\% 5 \mathrm{D}=3631$

Grevi, Giovanni, Ed. Mapping EU Strategic Partnerships. FRIDE Publication: 2011. Accessed February 2013. http://www.fride.org/publication/956/mapping-eu-strategicpartnerships

Haydon, Paul. "Human rights and the development of EU-China relations: a critical analysis of the EU's normative power." POLIS Journal, 5 (Summer 2011): 1-45. Accessed January 2013. http://www.polis.leeds.ac.uk/assets/files/students/studentjournal/ug-summer-11/paul-haydon.pdf

Herman, Hayley and Martyn Davies. "The EU and China: Prospects for Partnerships in Democracy Building in Africa." International Institute for Democracy and Electoral Assistance (2009): 1-13.

Holslag, Jonathan. "The Elusive Axis: Assessing the EU-China Strategic Partnership." Journal of Common Market Studies, 49:2 (2011): 293-313.

Holslag, Jonathan and Sara Van Hoeymissen, Eds. "The Limits of Socialization: The search for EU-China cooperation towards security challenges in Africa." Brussels Institute of Contemporary China Studies, Policy Report. (May 2010): 1-16. Accessed March 2013. http://www.vub.ac.be/biccs/site/assets/files/apapers/Policy\%20papers/EUChina-Africa\%20(fin).pdf 
Hopf, Ted. "The Promise of Constructivism in International Relations Theory." International Security, 23:1 (Summer 1998): 171-200.

Hyde-Price, Adrian. “'Normative' power Europe: a realist critique." Journal of European Public Policy, 13:2 (2006): 217-234.

Jacoby, Wade and Sophie Meunier. "Europe and the management of globalization." Journal of European Public Policy. 17: 3 (April 2010): 299-317.

Jian, Junbo. "A Clash of Civilization? Norms and Sino-EU Relations." International Review, Fourth (2008): 66, 71.

Jokela, Juha. "The European Union as an International Actor: Europeanization and Institutional Changes in the Light of the EU's Asia Policies." In The Role of the European Union in Asia: China and India as Strategic Partners. Edited by Bart Gaens, Juha Jokela and Eija Limnell, 37-53. Surrey: Ashgate Publishing, 2009.

Kerr, David and Liu Fei. "Introduction." The International Politics of EU-China Relations. Edited by David Kerr and Liu Fei, 1-10. Oxford: Oxford University Press, 2007.

Klenner, Wolfgang. "Economic Relations between the EU and China: Evolution of an Exclusive Partnership." China: An International Journal, 3:2 (September 2005): 331346.

Kliman, Daniel M. "Survey: EU More Likely to View China as Military Threat Than Previous Years," Video. September 24, 2012. Accessed December 2012. http://www.gmfus.org/archives/survey-eu-more-likely-to-view-china-as-military-threatthan-previous-years/

Kynge, James. "Africa, EU perspective." In China-EU, A Common Future. Edited by Stanley Crossick and Etienne Reuter, 145-148. Singapore: World Scientific Publishing Co., 2007.

Laïdi, Zaki, Ed. EU Foreign Policy in a Globalized World: Normative power and social preferences. London: Routledge, 2008.

Laïdi, Zaki. "Les conséquences inattendues de la puissance européenne." Garnet Policy Brief, Centre D'études Européennes (December 2007): 1-21.

Laïdi, Zaki. «Europe and World Governance Norms Over Force. » Sciences Po in China, Working Paper Series 2. (November 2007) : 1-16. 
Laïdi, Zaki. "European preferences and their reception." In EU Foreign Policy in a Globalised World: Normative Power and Social Preferences. Edited by Zaki Laïdi, 1-20. New York: Routledge, 2008.

Laïdi, Zaki. "BRICS: Sovereignty power and weakness." International Politics, 49:4 (2012): 614-632.

Laïdi, Zaki. "Europe Bets on Norms Rather Than on Force." World Chinese Cross Currents, $4: 3$ (2007)

Laïdi, Zaki. "Europe and World Governance Norms over Power." Governance and Globalization, Sciences Po in China, Working Paper Series 2 (November 2007) : 1-16.

Laursen, Finn. "The EU's Strategic Partnerships: The Case of EU-China Relations." Dalhousie EUCE Occasional Paper, 10 (2011) Accessed June 2012. http://euce.dal.ca/Files/EUCE_Occasional_Paper_No 10_2011.pdf

Li Jinshan. "Market Economy Status." In China-EU, A Common Future. Edited by Stanley Crossick and Etienne Reuter, 171-177. Singapore: World Scientific Publishing Co., 2007.

Liu, Lirong. "The EU and China's engagement in Africa: the dilemma of socialization." Institute for Security Studies Occasional Paper, 93 (July 2011): 1-41. Accessed February 2013.http://www.iss.europa.eu/uploads/media/The EU and Chinas engagement in Afr ica.pdf

Manners, Ian. "Normative Power Europe: A Contradiction in Terms?" Journal of Common Market Studies. 40.2 (2002): 235-258.

Manners, Ian. "The EU's Normative Power in Changing World Politics." In Normative Power Europe in a Changing World: A Discussion. Clingendael European Papers 5. Edited by André Gerrits, 9-24 (December 2009) Accessed May 2012. http://www.clingendael.nl/publications/2009/20091200 cesp paper_gerrits.pdf

March, James G. and Johan P. Olsen. "The logic of appropriateness." ARENA, Working Papers (September 2004): 1-28. Accessed March 2013. http://www.sv.uio.no/arena/english/research/publications/arenapublications/workingpapers/working-papers2004/wp04 9.pdf

Mattlin, Mikael. "A Normative EU Policy Towards China: Mission Impossible?" The Finnish Institute of International Affairs, Working Papers, 67 (2010): 1-26.

Mattlin, Mikael. "Thinking Clearly on Political Strategy: The Formulation of a Common EU Policy Toward China." In The Role of the European Union in Asia: China and India as Strategic Partners. Edited by Bart Gaens, Juha Jokela and Eija Limnell, 95-120. Surrey: Ashgate Publishing, 2009. 
Maull, Hanns W. "The European Union as civilian power: aspirations, potential, achievements." In US-China-EU Relations: Managing the new world order. Edited by Robert Ross, Øystein Tunsjø and Zhang Tuosheng, 48-76. London: Routledge, 2010.

Men, Jing. "Great expectations, complex reality." EU-China Observer, 3 (2011): 2-11. Accessed May 2012. http://www.coleurope.eu/sites/default/files/researchpaper/eu_china_observer_3 2009.pdf

Men, Jing and Giuseppe Balducci. "EU-China Relations in the 21st Century." In Prospects and Challenges for EU-China Relations in the 21st Century: The Partnership and Cooperation Agreement. Edited by Men Jing and Giuseppe Balducci, 21-32. Pieterlen, Switzerland: Peter Lang Publishing Group, 2010.

Meunier, Sophie and Kalypso Nicolaidis. "The European Union as a conflicted trade power." In The European Union and the New Trade Politics. Edited by John Peterson and Alasdair R. Young, 112-131, London: Routledge, 2007.

Norheim-Martinsen, Per M. "EU Strategic Culture: When the Means Becomes the End." Contemporary Security Policy, 32:3 (December 2011): 517-534.

Nouchetva, Gergana and Michael Emerson. "Economic Regimes for Exports: Extending the EU's Norms of Economic Governance into the Neighbourhood." Centre for European Policy Studies, Working Document, 233 (December 2005): 1-27.

Nugent, Neill. The Government and Politics of the European Union, $7^{\text {th }}$ Edition. New York: Palgrave MacMillan, 2010.

Odgaard, Liselotte and Sven Biscop. "The EU and China: Partners in Effective . Multilateralism?" In The International Politics of EU-China Relations, Edited by David Kerr and Liu Fei, 54-77. Oxford: Oxford University Press, 2007.

Palitza, Kristin. "Why Zambia's Elections Will Be All About China." Time, September 19, 2011. Accessed February 20, 2013. http://www.time.com/time/world/article/0,8599,2093381,00.html

Pan, Zhongqi. "Managing the conceptual gap on sovereignty in China-EU relations." Asia Europe Journal. 8 (2010): 227-243.

Plasschaert, Sylvain. "Is China Already a Market Economy?" Presentation at the Fondation Madariaga Conference, Is China Already a Market Economy? What Implications for the EU's Trade Defence Policy? 22 June 2012. Accessed on February 8 2013. http://www.madariaga.org/events/past-events-2012/713-is-china-already-amarketeconomy-what-implications-for-the-eu-trade-defence-policy 
Qin, Julia Ya. "“WTO-Plus" Obligations and Their Implications for the World Trade Organization Legal System: An Appraisal of the China Accession Protocol." Journal of World Trade, 37:3 (2003): 483-522.

Renard, Thomas. "The Treachery of Strategies: A call for true EU Strategic Partnerships." Egmont Paper, 45. (April 2011): 1-41.

Renard, Thomas, Ed. EU-China: Building Upon a Dialogue Among Strategic Partners, Conference Report. Gent, Belgium: Academia Press, 2011.

Renard, Thomas. The EU Strategic Partnerships Review: Ten Guiding Principles. European Strategic Partnerships Observatory, Policy brief, 2. (April 2012). Accessed March 2013. http://www.egmontinstitute.be/papers/12/secgov/ESPO_PB 2 2 TenPrinciples_FINAL.pdf

Romanova, Tatiana. "Normative Power Europe: A Russian View." In Normative Power Europe in a Changing World: A Discussion. Clingendael European Papers 5. Edited by André Gerrits, 51-60 (December 2009) Accessed May 2012.

http://www.clingendael.nl/publications/2009/20091200 cesp paper_gerrits.pdf

Sautenet, Antoine. " $L$ 'Europe et la Chine: une coopération aux dimensions juridiques complexes." Asie Visions, 3 (February 2008): 1-61. Accessed in February 2013. http://www.ifri.org/files/centre_asie/AsieVisions3_Sautenet_mars08.pdf

Schellhase, John. "China's Chad Courtship." The Diplomat, June 26, 2012. Accessed November 2012. http://thediplomat.com/china-power/chinas-chad-courtship/

Schimmelfenning, Frank. "Constructivism and EU Studies." Presentation at Comenius University, Bratislava, April 2008. Accessed January 2013. www.exu.sk/material/.../constructivism-and-EU-studies-Bratislava.ppt

Scott, David. "China-EU convergence 1957-2003: towards a 'strategic partnership." Asia-Europe Journal, 5 (2007): 217-233.

Scott, David. "The EU-China 'Strategic Dialogue': Pathways in the International System." In The International Politics of EU-China Relations. Edited by David Kerr and Liu Fei, 13-37. Oxford: Oxford University Press, 2007.

Shambaugh, David. "China and Europe: The Emerging Axis." The Brookings Institute (September 2004) Accessed April 2012, http://www.brookings.edu/research/articles/2004/09/china-shambaugh

Shambaugh, David, Eberghard Sandschneider and Zhou Hong. "From honeymoon to marriage: prospects for the China-Europe relationship." In China-Europe Relations: Perceptions, policies and prospects, Edited by David Shambaugh, Eberhard Sandschneider and Zhou Hong, 303-338. London: Routledge, 2008. 
Shambaugh, David. "China eyes Europe in the world: Real convergence or cognitive dissonance?" In China-Europe Relations: Perceptions, policies and prospects, Edited by David Shambaugh, Eberhard Sandschneider and Zhou Hong, 127-147. London: Routledge, 2008.

Shek, Colin. "Chinese media expands Africa presence." AlJazeera, January 24, 2013. Accessed January 24, 2013.

http://www.aljazeera.com/indepth/features/2013/01/201312071929822435.html

Shenhav, Shaul R. "Political Narratives and Political Reality." International Political Science Review, 27:3 (2006): 245-262.

Slaughter, Anne-Marie. "International Relations, Principal Theories." In Max Planck Encyclopedia of Public International Law. Edited by R. Wolfrum. Oxford: Oxford University Press, 2011. Accessed March 2013. http://www.princeton.edu/ slaughtr/Articles/722_IntlRelPrincipalTheories_Slaughter_20 110509zG.pdf

Smith, Karen E. "Beyond the civilian power debate." Politique Europeénne, 1:17. (2005): 63-82.

Stahl, Anna Katharina. "The EU Policy response to China's Resource Diplomacy in Africa." EU-China Observer, 4 (2011): 16-22. Accessed May 2012. http://www.coleurope.eu/sites/default/files/researchpaper/eu china observer 3 2009.pdf

Stahl, Anna Katharina. "Trilateral Development Cooperation between the European Union, China and Africa: What Prospects for South Africa?" Stellenbosch Discussion Paper 4 (August 2012): 1- 39.

Stanzel, Volker. "The EU and China in the global system." In China-Europe Relations: Perceptions, policies and prospects. Edited by David Shambaugh, Eberhard Sandschneider and Zhou Hong, 251-269, London: Routledge, 2008.

Stumbaum, May-Britt U. "Europe's views on China's role in international security." In China, Europe and International Security: Interests, Roles, and Prospects. Edited by Frans-Paul Van der Putten, and Chu Shulong, 7-19. London: Routledge 2010.

Struye de Swiedelande, Tanguy. "Offensive chinoise en Afrique." Note d'Analyse 3 , Programme "Union européenne - Chine," Chaire InBev Baillet-Latour (Avril 2009): 129. Accessed February 2013, http://www.uclouvain.be/cps/ucl/doc/pols/documents/NA3INBEV-FULL.pdf

Toje, Asle. "Normative Power in Europe after the Post-Cold War." In Normative Power Europe in a Changing World: A Discussion. Clingendael European Papers 5. Edited by 
André Gerrits, 37-50 (December 2009) Accessed May 2012.

http://www.clingendael.nl/publications/2009/20091200 cesp paper_gerrits.pdf

Tonra, Ben. "Democratic foundations of EU foreign policy: narratives and the myth of EU exceptionalism." Journal of European Public Policy, 18:8 (December 2011): 11901207.

Tywuschik, Veronika. "L'UE, la Chine et l'Afrique: Un partenariat triangulaire en théorie, à deux en pratique?" European Centre for Development Policy Management (ECDPM), Editorial, EU-Africa E-Alert No. 9. (2007) Accessed March 2013. http://www.ecdpm.org/Web_ECDPM/Web/Content/Download.nsf/0/4144DD25BC450B D6C1257332004493B9/\$FILE/L\%E2\%80\%99UE.\%201a\%20Chine\%20et\%201\%E2\%80 \%99Afrique.pdf

Van Lierde, Inès. "China: MES? The concerns of the EU Industry." Presentation at the Fondation Madariaga Conference, Is China Already a Market Economy? What Implications for the EU's Trade Defence Policy? 22 June 2012. Accessed on February 8 2013. http://www.madariaga.org/events/past-events-2012/713-is-china-already-amarketeconomy-what-implications-for-the-eu-trade-defence-policy

Vaïsse, Justin and Hans Kundnan. "European Foreign Policy Scorecard 2012," European Council on Foreign Relations, January 2012. Accessed on January 14, 2013, http://ecfr.eu/page/-/ECFR_SCORECARD 2012 WEB.pdf

Wacker, Gudrun. "Changes and continuities in EU-China relations : a German perspective. " In US-China-EU Relations: Managing the new world order. Edited by Robert Ross, Øystein Tunsjø and Zhang Tuosheng, 77-100. London: Routledge, 2010.

Wang, Yiwei. "The Identity Dilemmas of EU Normative Power: Observations from Chinese Traditional Culture." In Normative Power Europe in a Changing World: A Discussion. Clingendael European Papers 5. Edited by André Gerrits, $67-76$ (December 2009) Accessed May 2012.

http://www.clingendael.n//publications/2009/20091200 cesp paper_gerrits.pdf

Wendt, Alexander E. "The Agent-Structure Problem in International Relations Theory." International Organization, 41:3 (Summer, 1987): 335-370.

Whitman, Richard G. Normative Power Europe: Empirical and Theoretical Perspectives. Hampshire, UK: Palgrave Macmillan, 2011.

Wissenbach, Uwe. "The EU's response to China's Africa safari: Can triangulation match needs?" European Journal of Development Research, 21(2009): 662-67.

Wu Liming. "Commentary: Time for EU to recognize China's market economy status," Xinhua net, September 14, 2011, accessed February 82012 http://news.xinhuanet.com/english2010/indepth/2011-09/14/c_131138759.htm 
Young, Alasdair R. "Trade Politics Ain't What It Used to Be: The European Union in the Doha Round." Journal of Common Market Studies. 45:4 (2007): 789-811.

Young, Alasdair R. and John Peterson. "The EU and the new trade politics." In The European Union and the New Trade Politics. Edited by John Peterson and Alasdair R. Young, 1-20. London: Routledge, 2007.

Zhang, Jiao. "The EU-China Relationship Arriving at a Bottleneck- A Look at the Ongoing Negotiation of the PCA." EU-China Observer, 4 (2011): 2-8. Accessed May 2012. http://www.coleurope.eu/sites/default/files/researchpaper/eu china observer 4 2011.pdf

Zhang, Tiejun. « Sino-European Relations : From the Height to the Width. «In The Role of the European Union in Asia: China and India as Strategic Partners. Edited by Bart Gaens, Juha Jokela and Eija Limnell, 121-138. Surrey: Ashgate Publishing, 2009.

Zhang, Tiejun. "Africa- China perspective." In China-EU, A Common Future. Edited by Stanley Crossick and Etienne Reuter, 148-156. Singapore: World Scientific Publishing Co., 2007.

Zhang, Tuosheng. "On China's concept of the international security order." In US-ChinaEU Relations: Managing the new world order. Edited by Robert Ross, Øystein Tunsjø and Zhang Tuosheng, 26-47. London: Routledge, 2010.

Zhu, Liqun. "Chinese perceptions of the EU and the China-Europe relationship." In China-Europe Relations: Perceptions, policies and prospects. Edited by David Shambaugh, Eberhard Sandschneider and Zhou Hong, 148-173. London: Routledge, 2008.

Zielonka, Jan. "Europe's new civilizing missions: the EU's normative power discourse." Journal of Political Ideologies, 18:1 (2013): 35-55.

Zimmerman, Hubert. "Realist Power Europe? The EU in the Negotiations about China's and Russia's WTO Accession." Journal of Common Market Studies, 45:4 (November 2007): 813-838. 


\section{Primary Sources}

"'Americans are from Mars, Europeans from Venus."” The Telegraph, March 2, 2003. Accessed February 2013.

http://www.telegraph.co.uk/news/worldnews/northamerica/usa/1423535/Americans-arefrom-Mars-Europeans-from-Venus.html

"Barroso annonce un sommet UE-Chine pour "bientôt"." Le Monde, January 30, 2009. Accessed March 2013. http:/www.lemonde.fr/europe/article/2009/01/30/barrosoannonce-un-sommet-ue-chine-pour-bientot $1148502 \quad 3214 . \mathrm{html}$

Batzoglou, Ferry and Manfred Ertel. "Good Friends Are There to Help': Chinese Investors Take Advantage of Greek Crisis." Spiegel International, November 16, 2011. Accessed February 10, 2013. http://www.spiegel.de/international/europe/good-friendsare-there-to-help-chinese-investors-take-advantage-of-greek-crisis-a-797751.html

Bougon, Francois and Sébastien Hervieu. "Chine-Afrique: la fin de la lune de miel." Le Monde, March 23, 2013. Accessed April 1, 2013.

http://www.lemonde.fr/international/article/2013/03/22/chine-afrique-la-fin-de-la-lunede-miel $1852804 \quad 3210 . \mathrm{html}$

Chaffin, Joshua. "EU berates China on steel subsidies." Financial Times, January 14, 2013. Accessed February 27 2013, http://www.ft.com/intl/cms/s/0/6d4e6408-5e68-11 e2b3cb-00144feab49a.html\#axzz2KLqwLF00

“China's EU Policy Paper 2003." October 2003. Ministry of Foreign Affairs of the People's Republic of China. Accessed March 2012.

http://www.fmprc.gov.cn/eng/topics/ceupp/t27708.htm

"China pledges unconditional support to EU in debt crisis." Xinhua Net. September 20, 2011. Accessed October 2012. http://news.xinhuanet.com/english2010/china/2011$\underline{09 / 20 / \mathrm{c} 131149164 . \mathrm{htm}}$

"Commentary: Time for EU to recognize China's market economy status." Xinhua English News. Accessed February 82012

http://news.xinhuanet.com/english2010/indepth/2011-09/14/c 131138759.htm

Council of the European Union, Press Release. "Ninth EU-China Summit, Helsinki 9 September 2006, Joint Statement." 12642/06 (Presse 249) Accessed 16 February 2013 http://www.consilium.europa.eu/ueDocs/cms Data/docs/pressData/en/er/90951.pdf Council of the European Union, Press Release. "Human rights and democracy in the world." 10 May 2010. 9598/10 (Presse 110) Accessed January 2013 http://www.consilium.europa.eu/uedocs/cms_data/docs/pressdata/EN/foraff/114330.pdf

Council of the European Union, Press Release. "Joint Press Communiqué, $15^{\text {th }}$ EU-China Summit, Towards a stronger EU-China Comprehensive Strategic Partnership." 
September 20, 2012. 14022/12 (Presse 388) Accessed October 2012.

http://www.consilium.europa.eu/uedocs/cms data/docs/pressdata/en/ec/132507.pdf

Council of the European Union. EU Annual Report on Human Rights 2008. November 27, 2008. 14146/2/08, REV 2, COHOM 105. Accessed December 2012. http://www.consilium.europa.eu/uedocs/cmsUpload/st14146-re02.en08.pdf

Council of the European Union. « Declaration by the High Representative, Catherine Ashton, on behalf of the European Union on Tibetan self-immolations. " 14 December 2012. 17831/1/12 REV 1, PRESSE 535. Accessed February 2013, http://www.consilium.europa.eu/uedocs/cms data/docs/pressdata/en/cfsp/134378.pdf

Council of the European Union. Council Conclusions on trilateral dialogue and cooperation between the European Union, China and Africa, $2902^{\text {nd }}$ General Affairs Council Meeting, November 10 2008, available at: http://www.consilium.europa.eu/uedocs/cmsUpload/Eu-Africa103901.pdf (accessed February 2013)

Council of the European Union. Main aspects and basis choices of the CFSP (point G, paragraph 43 of the Interinstitutional Agreement of 17 May 2006) - 2011-Annual report from the High Representative of the European Union for Foreign Affairs and Security Policy to the European Parliament. 9 October, 2012. 14605/1/12 REV 1, PESC 1195 FI 724. Accessed February 2013. http://register.consilium.europa.eu/pdf/en/12/st14/st14605re01.en12.pdf

Delegation of the European Union to China. "Trade relations." Accessed January 2013, http://eeas.europa.eu/delegations/china/eu china/trade/index en.htm

Delegation of the European Union to China. "Human Rights Dialogue." Accessed January 2013, http://eeas.europa.eu/delegations/china/eu china/political relations/humain rights dialog ue/index en.htm

Delegation of the European Union to China. "Political and economic relations, the European Union and China: A Maturing Partnership." Accessed January 2013, http://eeas.europa.eu/delegations/china/eu_china/political_relations/index en.htm

Emmott, Robin and Alan Wheatley. "China must drop barriers to European investment, EU says." Reuters, June 7, 2012. Accessed on February 18, 2013.

http://www.reuters.com/article/2012/06/07/us-europe-china-investmentidUSBRE85611B20120607

European Commission. Joint Communication, Human Rights and Democracy at the heart of EU External Action- towards a more effective approach. December 12, 2011. $\operatorname{COM}(2011) 886$ final. Accessed May 2012. http://eurlex.europa.eu/LexUriServ/LexUriServ.do?uri=COM:2011:0886:FIN:EN:PDF 
European Commission. "Anti-dumping: Investigations." Accessed February 9, 2013. http://ec.europa.eu/trade/tackling-unfair-trade/trade-defence/antidumping/investigations/\#footnote-1.

European Commission. "Countries and Regions- China." Accessed January 2013, thttp://ec.europa.eu/trade/creating-opportunities/bilateral-relations/countries/china/

European Commission. "Facts and figures on EU-China trade- Did you know?" Accessed January 2013. http://trade.ec.europa.eu/doclib/docs/2009/september/tradoc 144591.pdf

European Commission. Commission staff working document on progress by the People's Republic of China towards graduation to market economy status in trade defence investigations. September 2009 19. SEC(2008) 2503 final. Accessed October 2012. http://trade.ec.europa.eu/doclib/docs/2009/june/tradoc 143599.pdf

European Commission, Press Release. "EU announces formal recognition of Russia as "Market Economy" in major milestone on road to WTO membership." IP/02/775, May 29, 2002, accessed 16 February 2013, http://europa.eu/rapid/press-release IP-02-775_en.htm

European Commission, Press Release. "WTO confirms China illegally imposed antidumping duties on scanners from the EU." IP/13/164, February 26, 2013, accessed 16 February 2013, http://europa.eu/rapid/press-release IP-13-164_en.htm

European Commission. "Fact sheet on trade relations with China, P.R. China, June 2009.", accessed September 2012, http://trade.ec.europa.eu/doclib/docs/2009/june/tradoc 143428.pdf

European Commission. A Single Market for $21^{\text {st }}$ Century Europe. November 20, 2007. $\operatorname{COM}(2007) 724$. Accessed January 2013 http://eurlex.europa.eu/LexUriServ/site/en/com/2007/com2007_0724en01.pdf

European Commission. Working Document Accompanying 'Closer Partners, Growing Responsibilities- $A$ policy paper on EU-China trade and investment: Competition and Partnership. ' $\{$ COM(2006) 631 final. $\}$ October 24, 2006. COM(2006) 632 final.

Accessed February 8, 2013.

http://trade.ec.europa.eu/doclib/docs/2006/october/tradoc 130791.pdf

European Commission. "Mandelson in China: EU-China trade deficit "measure of our untapped potential." " 27 November 2007. Accessed February 2013. http://trade.ec.europa.eu/doclib/docs/2008/january/tradoc_137536.pdf 
European Commission. Communication from the Commission, A Long Term Policy for China-Europe Relations. COM (1995) 279 final. Accessed May 2012. Available at: http://eeas.europa.eu/china/docs/com95 279 en.pdf

European Commission. Communication from the Commission, Global Europe: Competing in the World-A Contribution to the EU's Growth and Jobs Strategy. \{SEC(2006) 1228\}\{SEC(2006) 1229\}\{SEC(2006) 1230\}. April 10, 2006. COM(2006) 567 final. Accessed February 2013. http://eurlex.europa.eu/LexUriServ/LexUriServ.do?uri=COM:2006:0567:FIN:EN:PDF

European Commission. Communication from the Commission, Building a Comprehensive Partnership with China. March 25 1998. COM (1998) 181 final. Accessed May 2012. http://eur-lex.europa.eu/LexUriServ/LexUriServ.do?uri=COM:1998:0181:FIN:EN:PDF \

European Commission. Communication from the Commission, A maturing partnershipshared interests and challenges in EU-China relations. 10 September 2003. COM(2003) 533 final. Accessed May 2012. http://eurlex.europa.euexUriServ/LexUriServ.do?uri=COM:2003:0533:FIN:EN:PDF

European Commission. Communication from the Commission, EU-China: Closer partners, growing responsibilities. October 24, 2006, COM (2006) 631 final. Accessed May 2012. http://eur-

lex.europa.eu/LexUriServ/LexUriServ.do?uri=COM:2006:0631:FIN:EN:PDF

European Commission. "Progress towards meeting the economic criteria for accession: the assessments of the 2011 Progress Reports and the Opinion (Serbia)." DirectorateGeneral for Economic and Financial Affairs, European Economy, Occasional Papers, 85 (December 2011): 1-85.

European Commission, Communication from the Commission, Europe 2020: A strategy for smart, sustainable and inclusive growth, 3 March 2010, COM (2010), 2020 final, available at: http://eurlex.europa.eu/LexUriServ/LexUriServ.do?uri=COM:2010:2020:FIN:EN:PDF (accessed February 20 2013) 
European Commission. The EU, Africa and China: Towards trilateral dialogue and cooperation, 17 October 2008. COM (2008)654. Accessed January 2013 http://ec.europa.eu/development/icenter/repository/COMM PDF COM 20080654 F C OMMUNICATION en.pdf

European Commission. Commission staff working document, Accompanying the document, 'Report from the Commission to the European Parliament - 29th Annual Report from the Commission to the European Parliament on the EU's Anti-dumping, Anti-subsidy and Safeguard activities (2010) \{COM(2012) 59 final\}'. February 16, 2012. SWD(2012) 9 final. Accessed February 8, 2012.

http://trade.ec.europa.eu/doclib/docs/2012/may/tradoc 149395.pdf

European Council, Press Release. "Introductory remarks by Herman Van Rompuy, President of the European Council at the EU-China Summit." October 6, 2010. PCE 209/10. Accessed October 2012.

http://eeas.europa.eu/china/summit/summit_docs $/ 20120920$ hvr_opening_remarks_en.pd $\underline{\mathrm{f}}$

European Council, Press Release. " $13^{\text {th }}$ EU-China Summit Joint Press Communique." October 6, 2010. 14577/10 Presse (267). Accessed October 2012. http://www.consilium.europa.eu/uedocs/cmsUpload/116908.pdf

European Council, Press Release. "Opening remarks by President of the European Council Herman Van Rompuy at the $15^{\text {th }}$ EU-China Summit." September 20, 2012. EUCO 171/12 (Presse 387). Accessed October 2012. http://europa.eu/rapid/pressrelease PRES-12-387_en.htm

European Council. A Secure Europe in a Better World: European Security Strategy. December 12, 2003. Accessed May 2012. http://consilium.europa.eu/uedocs/cmsUpload/78367.pdf

European Council. Report on the Implementation of the European Security StrategyProviding Security in a Changing World. December 11, 2008. OJ S407/08. Accessed 20 February 2013

http://www.consilium.europa.eu/ueDocs/cms_Data/docs/pressdata/EN/reports/104630.pd $\underline{\mathbf{f}}$

European Council. "European Council, 16 September 2010 Conclusions." 12 October, 2010. EUCO 21/1/10, REV 1, CO EUR 16/CONCL 3. Accessed March 2013. http://www.consilium.europa.eu/uedocs/cms data/docs/pressdata/en/ec/116547.pdf 
European Parliament. "Delegation for Relations with the People's Republic of China." Accessed February 2013. http://www.europarl.europa.eu/meetdocs/2009 2014/documents/d$\underline{\mathrm{cn} / \mathrm{dv} / 789 / 789139 / 789139 \mathrm{en} . \mathrm{pdf}}$

European Parliament. European Parliament resolution of 13 December 2007 on the EUChina Summit and the EU/China human rights dialogue. 2007/2678(RSP). Accessed March 2013. http://www.europarl.europa.eu/sides/getDoc.do?type=TA\&reference=P6$\underline{T A-2007-0622 \& l a n g u a g e}=\mathrm{EN}$

European Parliament. The Human Rights Dialogue Between the EU and China. Briefing Paper. October 2007. Accessed May 2012.

http://www.europarl.europa.eu/committees/en/droi/studiesdownload.html?languageDocu $\underline{\text { ment }=\text { EN\&file }=18550}$

European Parliament. EU-China Trade Relations. Study. July 2011. EXPO/B/INTA/ FWC 2009-01/Lot7-14. Accessed January 2013.

http://www.europarl.europa.eu/committees/en/studiesdownload.html?languageDocument $=$ EN\&file $=48592$

European Parliament. European Parliament resolution of 23 April 2008 on China's policy and its effects on Africa. 2007/2255(INI). Accessed February 2013. http://www.europarl.europa.eu/meetdocs/2004_2009/documents/dv/d-cn20080602 09/DCN20080602_09en.pdf

European Union, External Action Service. "EU-China Dialogue Architecture- main elements." Accessed January 2013,

http://eeas.europa.eu/china/docs/eu_china_dialogues_en.pdf

European Union, External Action Service. "China." Accessed January 2013, http://eeas.europa.eu/china/index en.htm

European Union, Press Release. "Pascal Lamy EU Commissioner for Trade EU-China relations: continuity and change EU Chamber of Commerce in China Beijing." October 31, 2003. Speech/03/503. Accessed July 2012. http://europa.eu/rapid/pressrelease SPEECH-03-503 en.htm

European Union, Press Release. Catherine Ashton, EU High Representative for Foreign Affairs and Security Policy and Vice President of the European Commission: Speech on EU foreign policy towards the BRICS and other emerging powers." 1 February 2012. Speech/12/56/ Accessed March 2013. http://europa.eu/rapid/press-release_SPEECH-12$\underline{56 \text { en.htm }}$

European Union, Press Release. "Jose Manuel Durão Barroso, President of the European Commission: Peoples of yesterday, peoples of tomorrow: 35 years of EU/China 
relations." 30 April, 2010. Speech/10/199. Accessed October 2012. http://europa.eu/rapid/press-release SPEECH-10-199 en.htm

European Union. "China- Market economy status in trade defence investigations." 28 June 2004. Memo/04/163. Accessed on February 8, 2013. http://europa.eu/rapid/pressrelease MEMO-04-163 en.htm?locale=en

France Diplomatie, Ministère des Affaires Étrangères. «Les réalisations des PESC: L'action de l'Union européenne en faveur des droits de l'homme et de la démocratie. " Accessed February 2013. http://www.diplomatie.gouv.fr/fr/europe-828/unioneuropeenne-et-monde/politique-etrangere-et-de-securite/les-realisations-de-la-pesc/

France Diplomatie, Ministère des Affaires Étrangères. 'Les partenaires stratégiques de l'Union européenne.' Accessed March 2013. http://www.diplomatie.gouv.fr/fr/politiqueetrangere-de-la-france/europe-828/union-europeenne-et-monde/politique-etrangere-et-desecurite/les-realisations-de-la-pesc/article/les-partenaires-strategiques-de-l\#sommaire_3

France, Diplomatie, Ministère des Affaires Étrangères. "Le dialogue sur les droits de l'homme." Accessed January 2013. http://www.ambafrance-cn.org/Le-dialogue-sur-lesdroits-de-l-homme.html

Finkielsztoyn, Micaela, "EU-China relations: lessons for the future," The New Federalist, 30 December, 2012, accessed February 10, 2013, http://www.thenewfederalist.eu/EUChina-relations-lessons-for-the-future, 05432

"France joins China navy drills." CNN International, March 19, 2004. Accessed February 1, 2013. http://edition.cnn.com/2004/WORLD/asiapcf/03/16/china.navy/

"Hungary-China sign dozen agreements during state visit." Budapest Business Journal, June 26, 2011. Accessed February 10, 2013. http://www.bbj.hu/economy/hungary-chinasign-dozen-agreements-during-state-visit_58566

Kenety, Brian, "Rights: EUUnlikely To Endorse U.S. Proposal To Censure China." Inter Service Press, January 25, 2010. Accessed December 2012, http://www.ipsnews.net/2000/01/rights-euunlikely-to-endorse-us-proposal-to-censure-china/

La Guardia, Anton, "US fury over EU weapons for China," The Telegraph, 15 January, 2005, accessed on January 10, 2013, http://www.telegraph.co.uk/news/1481253/US-furyover-EU-weapons-for-China.html

"La rencontre entre le dalaï-lama et Merkel provoque l'ire de la Chine." Le Figaro, September 26, 2007. Accessed April 1, 2013. http://www.lefigaro.fr/international/2007/09/26/01003-20070926ARTFIG91526la rencontre entre le dalai lama et merkel provoque 1 ire de la chine.php 
Melvin, Don. "EU-China Summit Opens with Emphasis on Trade," Associated Press, September 20, 2012. Accessed December 4, 2012. http://bigstory.ap.org/article/eu-chinasummit-opens-emphasis-trade

"No need to nitpick over China's market economy status." People's Daily, September 28, 2011. Accessed in October 2012.

http://english.peopledaily.com.cn/90780/7606975.html

"Official: EU cannot "dictate" solutions to China's problems." People's Daily Online, April 16, 2008, http://english.people.com.cn/90001/90776/90883/6393222.html

Perlez, Jane. "With \$20 Billion Loan Pledge, China Strengthens Its Ties to African Nations." New York Times, July 19, 2012. Accessed October 2013.

http://www.nytimes.com/2012/07/20/world/asia/china-pledges-20-billion-in-loans-toafrican-nations.html? $\mathrm{r}=0$

"Premier Wen says China willing to help debt-ridden Europe." Xinhua English News. September 14, 2011. Accessed February 10, 2013.

http://news.xinhuanet.com/english2010/china/2011-09/14/c 131138103.htm

"Remarks by EU Council President Van Rompuy following EU-South Africa Summit," European Union External Action, http://www.eu-

un.europa.eu/articles/es/article_10129 es.htm

"Rencontre historique entre Sarkozy et le dalai-lama." Le Figaro, December 6, 2008.

Accessed February 18, 2013.

http:/www.lefigaro.fr/international/2008/12/06/01003-20081206ARTFIG00696-

premiere-rencontre-entre-sarkozy-et-le-dalai-lama-.php

Shinn, David H. "China's Deft Sudan Diplomacy." The Diplomat, September 19, 2012. Accessed February 27, 2013, http://thediplomat.com/china-power/chinas-deft-sudandiplomacy/

Smith, David. "Hillary Clinton launches African tour with veiled attack on China." The Guardian, August 1, 2012. Accessed October, 2012.

http://www.guardian.co.uk/world/2012/aug/01/hillary-clinton-africa-china

Solana, Javier. "Shaping an Effective EU Foreign Policy." Speech presented at the Konrad Adenauer Foundation, Brussels. January 24, 2005. Accessed May 2012. http://www.eu-un.europa.eu/articles/fr/article 4251 fr.htm 
Solana, Javier. "Securing Peace in Europe." Speech presented at Symposium on the Political Relevance of the 1648 Peace of Westphalia, 12 November, 1998. Accessed February 2013. http://www.nato.int/docu/speech/1998/s981112a.htm

"Sommet Chine-UE : Pékin réclame moins de protectionnisme commercial." Le Monde, September 20, 2012. Accessed January 2013. http://www.lemonde.fr/economie/article/2012/09/20/sommet-chine-ue-pekin-reclamemoins-de-protectionnisme-commercial 1763089 3234.html

"The EU-China Human Rights Dialogue: Perspectives from NGO Representatives." Human Rights In China (HRIC) China Rights Forum, Engaging Engagement:

Conversations and Reflections, 3 (2010) Accessed in October 2012, http://www.hrichina.org/content/3263

Wise, Peter and Leslie Hook. "China's State Grid to take $25 \%$ stake in REN." Financial Times, February 2, 2012. Accessed on February 25, 2012, http://www.ft.com/cms/s/0/41a0c572-4dba-11el-b96c00144feabdc0.html\#axzz2MVsQQcSW

World Economic Forum, "Premier Wen: China Will Do What It Can for Global Economic Stability and Recovery." World Economic Forum News Release, September 14, 2011. http://www.weforum.org/news/premier-wen-china-will-do-what-it-can-globaleconomic-stability-and-recovery

Représentation permanente de la France après de 1'Union Européenne. "Les Relations UE-Chine." Accessed on March 30 2013. http://www.rpfrance.eu/Les-relations-UEChine.html

World Trade Organization. 'Protocol on the Accession of the People's Republic of China." Accessed on February 82013. http://unpan1.un.org/intradoc/groups/public/documents/APCITY/UNPAN002123.pdf

World Trade Organization. "Uruguay Round Agreement: Agreement on Implementation of Article VI of the General Agreement on Tariffs and Trade 1994." Accessed March 2013. http://www.wto.org/english/docs e/legal e/19-adp 01 e.htm

\section{Interviews:}

Cameron, Fraser. Interview with Julie Pickering. May 2012, Brussels

Fiott, Daniel, Interview with Julie Pickering. May 2012, Brussels

Geeraerts, Gustaaf. Interview with Julie Pickering. May 2012, Brussels 
Renard, Thomas. Interview with Julie Pickering. May 2012, Brussels

Van de Camp, Wim, Interview with Julie Pickering. May 2012, Brussels 